Cover: Photograph of the Vendome Well, Chickasaw National Recreation Area, Sulphur, Oklahoma. Photograph by Scott Christenson, U.S. Geological Survey. 


\section{Geochemical Investigation of the Arbuckle-Simpson Aquifer, South-Central Oklahoma, 2004-06}

By Scott Christenson, Andrew G. Hunt, and David L. Parkhurst

In cooperation with the Oklahoma Water Resources Board

Scientific Investigations Report 2009-5036 


\section{U.S. Department of the Interior \\ KEN SALAZAR, Secretary}

\section{U.S. Geological Survey Suzette M. Kimball, Acting Director}

U.S. Geological Survey, Reston, Virginia: 2009 This and other USGS information products are available at http://store.usgs.gov/
U.S. Geological Survey
Box 25286 , Denver Federal Center
Denver, CO 80225
To learn about the USGS and its information products visit http://www.usgs.gov/
1-888-ASK-USGS

Any use of trade, product, or firm names is for descriptive purposes only and does not imply endorsement by the U.S. Government.

Although this report is in the public domain, permission must be secured from the individual copyright owners to reproduce any copyrighted materials contained within this report.

Suggested citation:

Christenson, Scott, Hunt, A.G., and Parkhurst, D.L., 2009, Geochemical investigation of the Arbuckle-Simpson aquifer, South-central Oklahoma, 2004-06: U.S. Geological Survey Scientific Investigations Report 2009-5036, 50 p. 


\section{Contents}

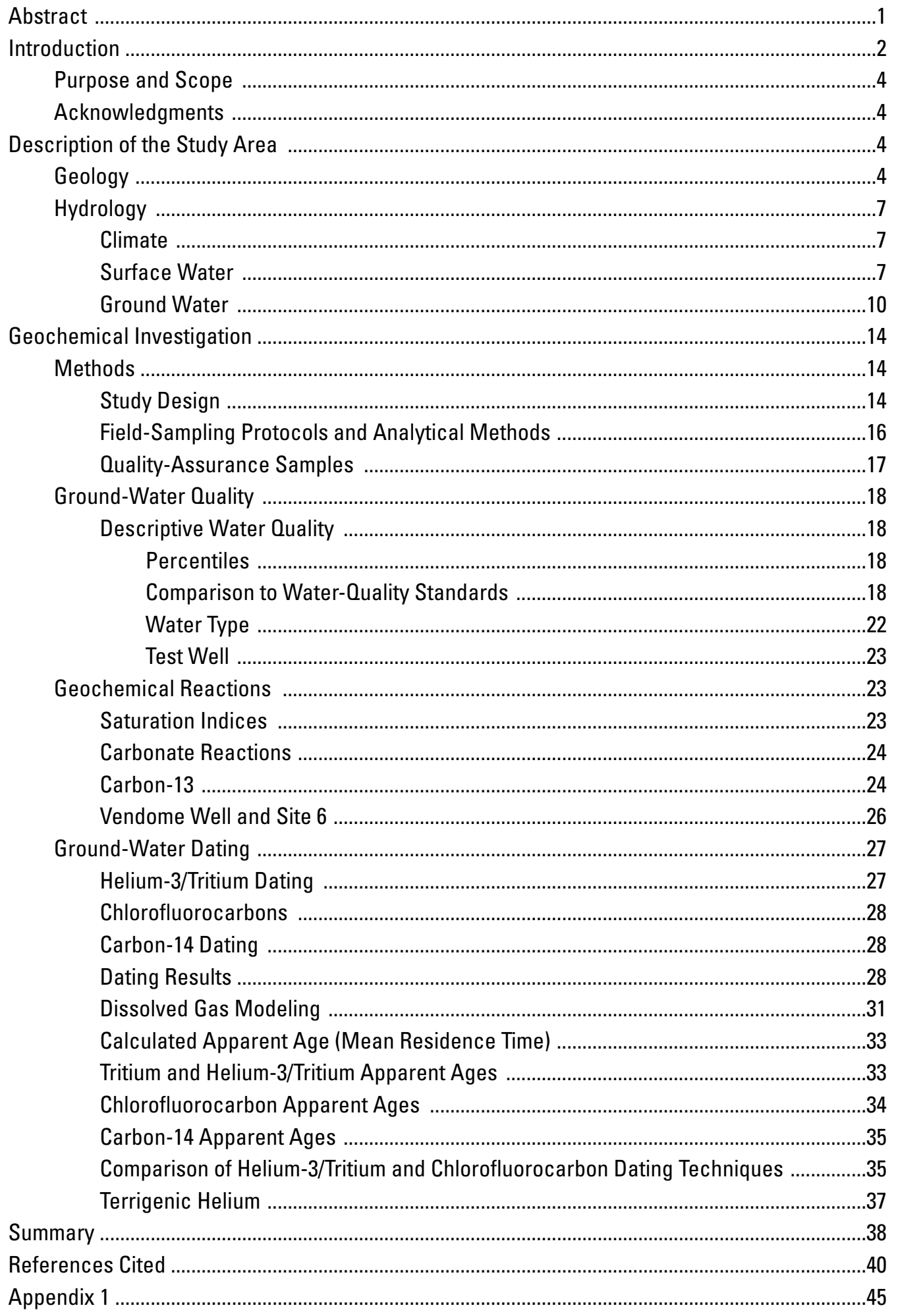




\section{Figures}

1-8. Maps showing:

1. Location of the Arbuckle-Simpson aquifer and study area, south-central Oklahoma

2. Geographic features of the Arbuckle-Simpson aquifer study area, southcentral Oklahoma

3. Geologic map of the Arbuckle-Simpson aquifer study area, south-central Oklahoma

4. Perennial streams with drainage basins that include the Arbuckle-Simpson aquifer, south-central Oklahoma

5. Springs listed in the U.S. Geological Survey's National Water Information System database within the Arbuckle-Simpson aquifer study area, southcentral Oklahoma

6. Potentiometric surface in the Hunton Anticline, June 2005, south-central Oklahoma

7. Locations of the Arbuckle-Simpson aquifer geochemical sampling sites, south-central Oklahoma

8. Stiff diagrams of the Arbuckle-Simpson aquifer geochemical reconnaissance samples, south-central Oklahoma

9. Calcite and dolomite saturation indices and log partial pressure of carbon dioxide

10. Relation between neon-to-xenon ratio and argon concentration 30

11. Historical measured tritium $\left({ }^{3} \mathrm{H}\right)$ values in precipitation from R.L. Michel and the calculated ${ }^{3} \mathrm{H}$ levels present

12. Comparison of reconstructed initial tritium (tritium $\left[{ }^{3} \mathrm{H}\right]$ plus tritiogenic helium-3 $\left.\left[{ }^{3} \mathrm{He}^{*}\right]\right)$ to historical tritium input levels

13. Comparison of helium-3/tritium $\left({ }^{3} \mathrm{He} /{ }^{3} \mathrm{H}\right)$ and chlorofluorocarbon (CFC) dating techniques

\section{Tables}

1. Monthly and annual average precipitation at Ada, Oklahoma (1971-2000) .....................7

2. Monthly and annual average temperature at Ada, Oklahoma (1971-2000) .......................7

3. Analytes and schedules for Arbuckle-Simpson geochemical sampling .......................15

4. Constituent concentrations and relative percent difference between an environmental sample (site number 29) and a replicate sample

5. Summary statistics for physcial properties and chemical constituents from the Arbuckle-Simpson Hydrology Study geochemical reconnaissance samples ................20

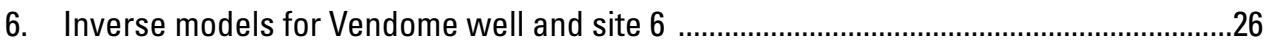

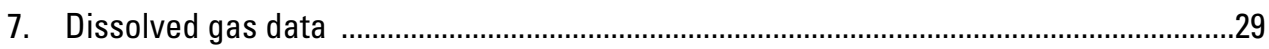

8. Dissolved gas modeling and helium-3/tritium $\left({ }^{3} \mathrm{He} /{ }^{3} \mathrm{H}\right)$ age determination ......................32

9. Chlorofluorocarbon data and age calculation .............................................................36 


\section{Conversion Factors, Datums, and Abbreviations}

\section{Inch/Pound to SI}

\begin{tabular}{|c|c|c|}
\hline Multiply & By & To obtain \\
\hline \multicolumn{3}{|c|}{ Length } \\
\hline inch (in.) & 2.54 & centimeter $(\mathrm{cm})$ \\
\hline inch (in.) & 25.4 & millimeter $(\mathrm{mm})$ \\
\hline foot $(\mathrm{ft})$ & 0.3048 & meter $(\mathrm{m})$ \\
\hline mile (mi) & 1.609 & kilometer $(\mathrm{km})$ \\
\hline \multicolumn{3}{|c|}{ Area } \\
\hline square mile $\left(\mathrm{mi}^{2}\right)$ & 2.590 & square kilometer $\left(\mathrm{km}^{2}\right)$ \\
\hline \multicolumn{3}{|c|}{ Volume } \\
\hline gallon (gal) & 3.785 & liter (L) \\
\hline acre-foot (acre-ft) & 1,233 & cubic meter $\left(\mathrm{m}^{3}\right)$ \\
\hline \multicolumn{3}{|c|}{ Flow rate } \\
\hline cubic foot per second $\left(\mathrm{ft}^{3} / \mathrm{s}\right)$ & 0.02832 & cubic meter per second $\left(\mathrm{m}^{3} / \mathrm{s}\right)$ \\
\hline gallon per minute (gal/min) & 0.06309 & liter per second $(\mathrm{L} / \mathrm{s})$ \\
\hline \multicolumn{3}{|c|}{ Pressure } \\
\hline atmosphere, standard (atm) & 101.3 & kilopascal (kPa) \\
\hline \multicolumn{3}{|c|}{ Transmissivity $^{1}$} \\
\hline foot squared per day $\left(\mathrm{ft}^{2} / \mathrm{d}\right)$ & 0.09290 & meter squared per day $\left(\mathrm{m}^{2} / \mathrm{d}\right)$ \\
\hline
\end{tabular}

${ }^{1}$ Transmissivity: The standard unit for transmissivity is cubic foot per day per square foot times foot of aquifer thickness $\left(\left[\left(\mathrm{ft}^{3} / \mathrm{d}\right) / \mathrm{ft}^{2}\right] / \mathrm{ft}\right)$. In this report, the mathematically reduced form, foot squared per day ( $\left.\mathrm{ft}^{2} / \mathrm{d}\right)$, is used for convenience.

Temperature in degrees Celsius $\left({ }^{\circ} \mathrm{C}\right)$ may be converted to degrees Fahrenheit $\left({ }^{\circ} \mathrm{F}\right)$ as follows:

${ }^{\circ} \mathrm{F}=\left(1.8 x^{\circ} \mathrm{C}\right)+32$

\section{Datums}

Vertical coordinate information is referenced to the National Geodetic Vertical Datum of 1988 (NAVD88).

Horizontal coordinate information is referenced to the North American Datum of 1927 (NAD27) or the North American Datum of 1983 (NAD83).

Altitude, as used in this report, refers to distance above the vertical datum.

\section{Abbreviations}

Specific conductance is given in microsiemens per centimeter at 25 degrees Celsius $(\mu \mathrm{S} / \mathrm{cm})$.

Concentrations of chemical constituents in water are given either in milligrams per liter (mg/L) or micrograms per liter $(\mu \mathrm{g} / \mathrm{L})$.

Concentrations of chloroflurocarbons are given in picograms per kilogram $(\mathrm{pg} / \mathrm{kg})$, picomoles per kilogram (pmol/kg), or parts per trillion (ppt).

Concentrations of dissolved gasses are given in cubic centimeters per kilogram (cc/kg) or micro-cubic centimeters per kilogram ( $\mu \mathrm{cc} / \mathrm{kg})$.

Concentrations of tritium are given in tritium units (TU). 
Permil: A unit expressing the ratio of stable-isotope abundances of an element in a sample to those of a standard material. Permil for stable isotopes are calculated as follows:

$$
\delta_{\text {Sample }}=1,000\left(\frac{R_{\text {Sample }}-R_{\text {Standard }}}{R_{\text {Standard }}}\right),
$$

where $R$ is the isotopic ratio of the least abundant isotope to the most abundant isotope. The following standards are used for reporting isotopes: Hydrogen-2/Hydrogen-1, VSMOW (Vienna Standard Mean Ocean Water); Oxygen-18/0xygen-16, VSMOW; and Carbon-13/Carbon-12, VPDB (Vienna Pee Dee Belemnite) (Appelo and Postma, 2005). 


\title{
Geochemical Investigation of the Arbuckle-Simpson Aquifer, South-Central Oklahoma, 2004-06
}

\author{
By Scott Christenson, Andrew G. Hunt, and David L. Parkhurst
}

\section{Abstract}

A geochemical reconnaissance investigation of the Arbuckle-Simpson aquifer in south-central Oklahoma was initiated in 2004 to characterize the ground-water quality at an aquifer scale, to describe the chemical evolution of ground water as it flows from recharge areas to discharge in wells and springs, and to determine the residence time of ground water in the aquifer. Thirty-six water samples were collected from 32 wells and springs distributed across the aquifer for chemical analysis of major ions, trace elements, isotopes of oxygen and hydrogen, dissolved gases, and age-dating tracers.

In general, the waters from wells and springs in the Arbuckle-Simpson aquifer are chemically suitable for all regulated uses, such as public supplies. Dissolved solids concentrations are low, with a median of 347 milligrams per liter $(\mathrm{mg} / \mathrm{L})$. Two domestic wells produced water with nitrate concentrations that exceeded the U.S. Environmental Protection Agency's nitrate maximum contaminant level (MCL) of $10 \mathrm{mg} / \mathrm{L}$. Samples from two wells in the confined part of the aquifer exceeded the secondary maximum contaminant level (SMCL) for chloride of $250 \mathrm{mg} / \mathrm{L}$ and the SMCL of $500 \mathrm{mg} / \mathrm{L}$ for dissolved solids. Water samples from these two wells are not representative of water samples from the other wells and springs completed in the unconfined part of the aquifer. No other water samples from the Arbuckle-Simpson geochemical reconnaissance exceeded MCLs or SMCLs, although not every chemical constituent for which the U.S. Environmental Protection Agency has established a MCL or SMCL was analyzed as part of the Arbuckle-Simpson geochemical investigation.

The major ion chemistry of 34 of the 36 samples indicates the water is a calcium bicarbonate or calcium magnesium bicarbonate water type. Calcium bicarbonate water type is found in the western part of the aquifer, which is predominantly limestone. Calcium magnesium bicarbonate water is found in the eastern part of the aquifer, which is predominantly a dolomite. The major ion chemistry for these 34 samples is consistent with a set of water-rock interactions. Rainfall infiltrates the soil zone, where the host rock, limestone or dolomite, dissolves as a result of uptake of carbon dioxide gas. Some continued dissolution of dolomite and precipitation of calcite occur as the water flows through the saturated zone.
The major ion chemistry of the two samples from wells completed in the confined part of the aquifer indicates the water is a sodium chloride type. Geochemical inverse modeling determined that mixing of calcite-saturated recharge water with brine and dissolving calcite, dolomite, and gypsum accounts for the water composition of these two samples. One of the two samples, collected at Vendome Well in Chickasaw National Recreation Area, had a mixing fraction of brine of about 1 percent. The brine component of the sample at Vendome Well is likely to account for the relatively large concentrations of many of the trace elements (potassium, fluoride, bromide, iodide, ammonia, arsenic, boron, lithium, selenium, and strontium) measured in the water sample.

Carbon-14, helium-3/tritium, and chlorofluorocarbons were used to calculate ground-water ages, recharge temperatures, and mixtures of ground water in the ArbuckleSimpson aquifer. Thirty four of 36 water samples recharged the aquifer after 1950, indicating that water is moving quickly from recharge areas to discharge at streams and springs. Two exceptions to this classification were noted in samples 6 and 15 (Vendome Well). Ground-water ages determined for these two samples by using carbon-14 are 34,000 years (site 6) and 10,500 years (site 15).

Concentrations of dissolved argon, neon, and xenon in water samples were used to determine the temperature of the water when it recharged the aquifer. The mean annual air temperature at Ada, Oklahoma, is 16 degrees Celsius $\left({ }^{\circ} \mathrm{C}\right)$ and the median temperature of the 30 reconnaissance water samples was $18.1^{\circ} \mathrm{C}$. The average recharge temperature of most samples is $14.3+/-2.2^{\circ} \mathrm{C}$, which is below the mean annual air temperature $\left(16^{\circ} \mathrm{C}\right)$. Calculating a weighted annual recharge temperature based on mean monthly recharge rates from hydrograph separation techniques and mean monthly air temperature at Ada, Oklahoma, produces a value of $14.2^{\circ} \mathrm{C}$. The weighted annual recharge temperature corroborates the calculated noble gas recharge temperatures and indicates that recharge occurs during the cooler months of the year. Recharge temperatures of water samples from sites 6 and 15, the two flowing wells producing water from confined parts of the aquifer, are clearly too cold $\left(8.2\right.$ and $6.6^{\circ} \mathrm{C}$, respectively) to be associated with present day temperatures. The colder recharge temperatures are consistent with the ground-water ages for these samples $(34,000$ years for site 6 and 10,500 
years for site 15), indicating recharge from an earlier, cooler time period, coupled with possible mass fractionation of the noble gases that decreases the overall recharge temperature.

\section{Introduction}

The Arbuckle-Simpson aquifer is located in Carter, Coal, Johnston, Murray, and Pontotoc Counties in south-central Oklahoma (fig. 1). The aquifer was estimated to contain about 9 million acre-feet of freshwater by Fairchild, Hanson, and Davis (1990). Freshwater from the aquifer supplies base flow to the Blue River, Byrds Mill Creek, Delaware Creek, Honey Creek, Mill Creek, Oil Creek, Pennington Creek, Rock Creek, Travertine Creek, and many small streams (fig. 2). Springs, including Byrds Mill Spring (the primary water supply for the City of Ada), and the springs in the Chickasaw National Recreation Area discharge from the aquifer. Wells completed in the aquifer supply water to cities (including Sulphur and Ada), industry, agriculture, and local residents.

In 2002, in search of future water supplies, the Central Oklahoma Water Resource Authority, consisting primarily of communities in Canadian County, Oklahoma, proposed to purchase water from the Arbuckle-Simpson aquifer, drill wells, and build an 88-mile pipeline from the Arbuckle-Simpson aquifer to Canadian County in central Oklahoma (Oklahoma Water Resources Board, 2003, p. 1). In Oklahoma, ground water is considered private property that belongs to the overlying surface owner. Thus, the planned withdrawal and transfer of water by the Central Oklahoma Water Resource Authority was considered by the State of Oklahoma to be a permissible use of ground water. However, local residents, citizens' groups, and the National Park Service were concerned that large-scale withdrawals of water from the Arbuckle-Simpson aquifer would cause decreased flow in rivers and springs, which in turn could result in the loss of water supplies, recreational opportunities, and aquatic habitat. The withdrawals also could cause water levels in the aquifer to decrease, which could increase pumping costs and require replacement of public and domestic water-supply wells. Many protests were filed with the Oklahoma Water Resources Board regarding the planned water transfer.

In response to these concerns, the Oklahoma Senate passed Senate Bill 288, which imposed a moratorium on the issuance of any temporary ground-water permits for municipal or public water supply outside of any county that overlies a "sensitive sole source groundwater basin;" the ArbuckleSimpson aquifer is the only aquifer in Oklahoma classified as sole source (Oklahoma Water Resources Board, 2003, p. 1). Senate Bill 288 states that the moratorium will remain in effect until the Oklahoma Water Resources Board completes a study of the Arbuckle-Simpson aquifer and determines a maximum annual yield.

The Oklahoma Water Resources Board, in collaboration with the U.S. Bureau of Reclamation, the U.S. Geological Survey, Oklahoma State University, and the University of Oklahoma, initiated a comprehensive multi-year investigation of south-central Oklahoma's Arbuckle-Simpson aquifer (Oklahoma Water Resources Board, 2003, p. 2). The study is known

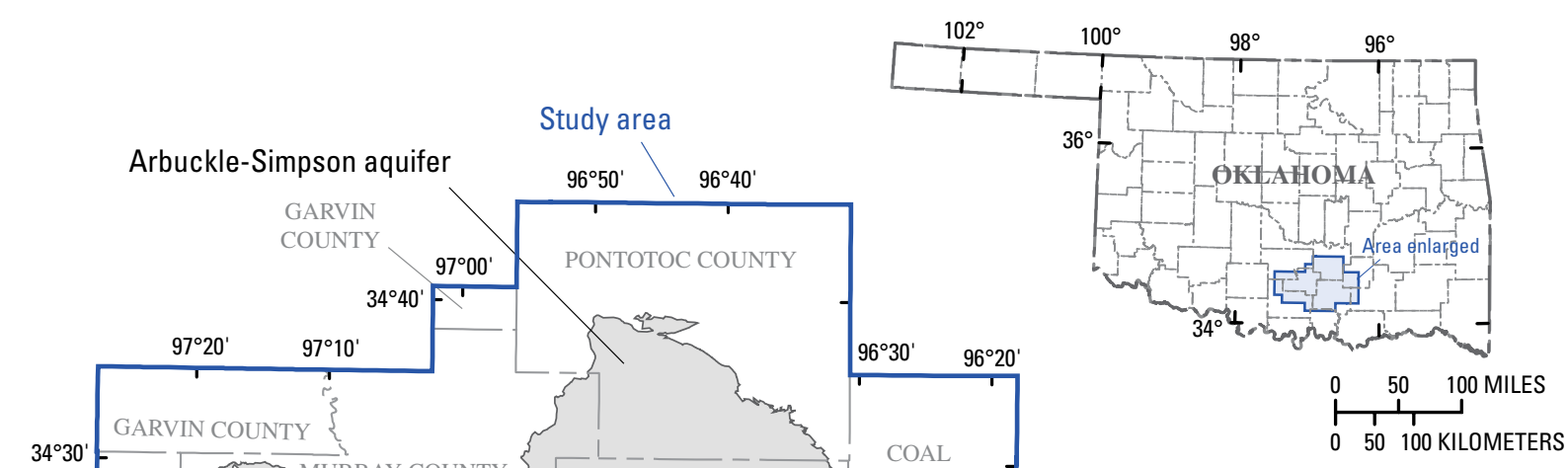

LOCATION MAP

Figure 1. Location of the Arbuckle-Simpson aquifer and study area, south-central Oklahoma. 


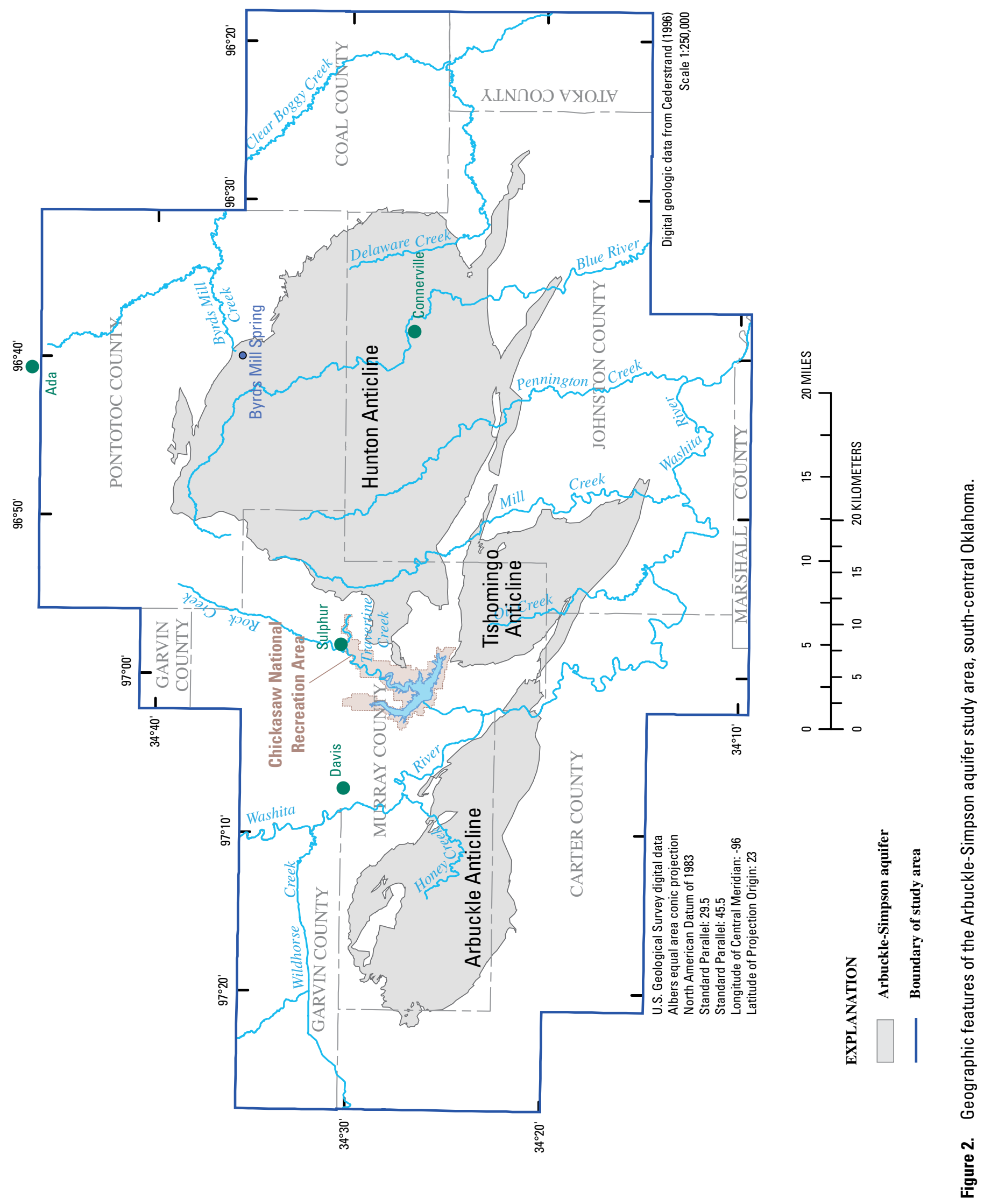


as the "Arbuckle-Simpson Hydrology Study." The objectives of the Arbuckle-Simpson Hydrology Study are as follows:

1. Characterize the Arbuckle-Simpson aquifer in terms of geologic setting, aquifer boundaries, hydraulic properties, water levels, ground-water flow, recharge, discharge, and water budget.

2. Characterize the area's surface hydrology, including stream and spring discharge, runoff, base flow, and the relationship of surface water to ground water.

3. Construct a digital ground-water/surface-water flow model of the Arbuckle-Simpson aquifer system for use in evaluating the allocation of water rights and simulating management options.

4. Determine the chemical quality of the aquifer and principal streams, identify potential sources of natural contamination, and delineate areas of the aquifer that are most vulnerable to contamination.

5. Construct network stream models of the principal stream systems for use in the allocation of water rights.

6. Propose water management options, consistent with state water laws, that address water rights issues, the potential impacts of pumping on springs and stream base flows, water quality, and water supply development.

An investigation of the geochemistry of the ArbuckleSimpson aquifer, conducted by the U.S. Geological Survey in cooperation with the Oklahoma Water Resources Board, was initiated in partial fulfillment of objectives 1 and 4.

\section{Purpose and Scope}

This report documents an investigation of the geochemistry of the Arbuckle-Simpson aquifer that was initiated in 2004 to characterize the ground-water quality at an aquifer scale, describe the chemical evolution of ground water as it flows from recharge areas to discharge in wells and springs, and to determine the residence time of ground water in the aquifer. This report presents some information about the geology and hydrology of the aquifer but only as background information for the discussion of the geochemistry of the aquifer. The information in this report is partial fulfillment of objectives 1 and 4 of the Arbuckle-Simpson Hydrology Study.

This report uses chemical analyses of spring and groundwater samples to describe the water quality and geochemistry of the aquifer. The description of the water quality consists of descriptive statistics of physical properties and chemical constituents in water samples, comparison to water-quality standards, and a map showing water type. The investigation of the geochemistry of the aquifer consisted of identification of geochemical processes affecting the major ion chemistry of the aquifer and use of tracers (such as carbon-14, tritium, chlorofluorocarbons, and dissolved gases) to determine groundwater ages and to identify ground-water flow processes.

\section{Acknowledgments}

The authors are indebted to the many land owners, municipalities, and operators of rural water districts who provided access to the wells and springs sampled during this investigation. This report would not have been possible without their assistance and their permission to work on their land and facilities.

The Arbuckle-Simpson Hydrology Study was conceived and directed by the Oklahoma Legislature and the staff and board members of the Oklahoma Water Resources Board. Many members of the Legislature, Board, and staff contributed to this study. In particular, Noel Osborn, staff geologist with the Oklahoma Water Resources Board, provided leadership and vision for the study, and participated in the data collection and analysis.

The authors also wish to thank Dale Ferree, Shana Mashburn, and Jason Masoner of the U.S. Geological Survey Oklahoma Water Science Center for assistance in collecting water samples, and Dr. Ann Azadpour-Keeley with the U.S. Environmental Protection Agency's Robert S. Kerr Environmental Research Laboratory, for providing bacteriological analyses of water samples.

\section{Description of the Study Area}

The Arbuckle-Simpson aquifer crops out in south-central Oklahoma over an area of about 520 square miles (fig. 2). The aquifer underlies parts of Carter, Coal, Johnston, Murray, and Pontotoc Counties. Data outside the aquifer outcrop were considered to be useful in studying the aquifer, and thus a study area was defined at the beginning of the study on the basis of a set of townships in the public land survey system that extended beyond the perimeter of the aquifer. The study area includes 56 townships ( 2,016 square miles).

\section{Geology}

The Arbuckle-Simpson aquifer consists of the Timbered Hills, Arbuckle, and Simpson Groups, a group being a stratigraphic unit consisting of two or more formations deposited during a single geologic era. No confining layer separates the Timbered Hills Group from the Arbuckle Group and thus Timbered Hills Group is included in the Arbuckle-Simpson aquifer and is considered to be part of the same ground-water flow system.

A detailed discussion of the geologic units that compose the Arbuckle-Simpson aquifer and adjacent formations is beyond the scope of this report. More comprehensive descriptions of the geology of the Arbuckle-Simpson aquifer and adjacent formations can be found in Ham (1955), Ham (1973), and Johnson (1991).

The aquifer study area commonly is divided into three areas, which are designated as the Hunton, Tishomingo, and 
Arbuckle Anticlines in this report (fig. 2). These designations are based loosely on geologic and topographic similarities, and the terms are not based strictly on geologic structures. The aquifer and bounding geohydrologic units are described herein in order from oldest to youngest.

The Arbuckle-Simpson aquifer is underlain by Cambrian and Precambrian rhyolite and granite basement rocks. The basement rocks are as deep as about 8,000 feet in the few wells that penetrate the outcrop of the aquifer (Campbell and Weber, 2006). These basement rocks are at the land surface in the geologic structural center of the Arbuckle Anticline, as a few small inliers within the Tishomingo Anticline, and south of the Hunton Anticline where faulting has elevated them to the land surface (fig. 3).

The Cambrian-age Timbered Hills Group ranges in thickness in the study area from 0 to about 700 feet (Fairchild, Hanson, and Davis, 1990) and consists of the Reagan Sandstone and Honey Creek Limestone. The Reagan Sandstone is composed primarily of quartz grains with some feldspar and glauconite (Ham, 1955). The Honey Creek Limestone is a limestone in the Arbuckle Anticline and a dolomite in other exposures within the study area. The Timbered Hills Group is at the land surface in only a small percentage of the outcrop of the Arbuckle-Simpson aquifer, about 8 square miles (fig. 3). The Timbered Hills Group is at the land surface in the geologic structural center of the Arbuckle Anticline, at the eastern edge of the Tishomingo Anticline, and at the southern edge of the Hunton Anticline.

The Arbuckle Group, of Late Cambrian to Middle Ordovician age (fig. 3), consists of the Fort Sill Limestone, Royer Dolomite, Signal Mountain Formation, Butterly Dolomite, McKenzie Hill Formation, Cool Creek Formation, Kindblade Formation, and West Spring Creek Formation. Although the Arbuckle Group has been subdivided into geologic units based on a combination of lithostratigraphic and biostratigraphic parameters (Donovan, 1991), these geologic units are difficult to distinguish in the field and, as a consequence, the Arbuckle Group is treated as a single geologic unit in this report. The Arbuckle Group is thickest in the Arbuckle Anticline, as much as 6,700 feet (Ham, 1955), and thins to about 3,000 feet to the north and east in the Hunton Anticline (Campbell and Weber, 2006). The Arbuckle Group consists largely of carbonates with a few thin layers of sandstone and shale. Chert is abundant in some geologic units, and traces of evaporites can be found (Donovan, 1991). Limestone is the dominant carbonate in the Arbuckle Anticline, but to the north and east a transition to dolomite occurs in the Hunton Anticline (Ham, 1955). The Arbuckle Group is the dominant geologic unit at the land surface within the outcrop of the Arbuckle-Simpson aquifer with an outcrop area of about 360 square miles.

The Simpson Group of Ordovician age ranges in thickness in the study area from 0 , where the Simpson Group has been removed by erosion, to 2,300 feet (Fairchild, Hanson, and Davis, 1990), and consists of the Joins Formation, Oil Creek Formation, McLish Formation, Tulip Creek Formation, and Bromide Formation. The Joins Formation is a thin-bedded limestone but the other formations consist of a basal sandstone, a middle shale, and an upper limestone (D.L. Hart, U.S. Geological Survey, written commun., 1972). The sandstones are 50 to 350 feet thick and consist of well-sorted, rounded, and frosted quartz grains that make excellent petroleum reservoirs outside of the outcrop of the Arbuckle-Simpson aquifer. Within the outcrop they are mined as high-purity sands for the manufacture of glass and other industrial uses (Ham, 1973). The Simpson Group covers an area of about 145 square miles of the land surface within the outcrop area of the ArbuckleSimpson aquifer and is at the land surface over a large area of the eastern part of the Hunton Anticline. Other areas where the Simpson Group is at the land surface include the southern and western boundaries of the Arbuckle and Tishomingo Anticlines, the northern boundaries of the Arbuckle and Hunton Anticlines, and southeast of Sulphur (fig. 3).

The outcrop of the Arbuckle-Simpson aquifer represents a structural high, and outside of the outcrop of the aquifer the geologic units that comprise the aquifer are buried by younger rocks, except to the south where the basement rocks abut the aquifer. The upper surface of the geologic units in the Arbuckle-Simpson aquifer outside the outcrop area is an unconformity and many different geologic units overlie the aquifer, depending on location, including the Viola Group, Sylvan Shale, Hunton Group, Woodford Shale, and a variety of Mississippian geologic units (Donovan, 1991). Near the Chickasaw National Recreation Area (fig. 2), the ArbuckleSimpson aquifer is overlain by the Pennsylvanian-age Vanoss Group, which consists of a tightly cemented limestone conglomerate, a shale member, and minor sandstone lentils (Hanson and Cates, 1994). All geologic units younger than the Simpson Group are designated in this report as postSimpson geologic units, undifferentiated. In many locations the Arbuckle and Simpson Groups dip into the subsurface, such as near the Chickasaw National Recreation Area near Sulphur; in other locations faulting places the geologic units discontinuously in the subsurface, such as at the northeast boundary of the Hunton Anticline.

The Arbuckle-Simpson aquifer is highly folded, faulted, and fractured. The rocks were subjected to intensive folding and faulting associated with major uplift of the area during early to late Pennsylvanian time. Features characteristic of Arbuckle Group deformation include an abundance of brittle fracturing (joints, shears, broken or collapsed folds), parallel folding, and pressure solution (Donovan, 1991). Major faults have offset stratigraphic units as much as 40 miles (Scheirer and Hosford Scheirer, 2006). Structural deformation increases to the southwest; rocks are more flat lying in the Hunton Anticline (dips less than 20 degrees), but tilting increases to the southwest with vertical and overturned beds to be found within the Arbuckle Anticline.

Small karst features can be seen over much of the outcrop area of the aquifer, but human-enterable air-filled caves are found only in a few locations. Lynch and Al-Shaieb (1991) document evidence of extensive paleokarst in Arbuckle Group 

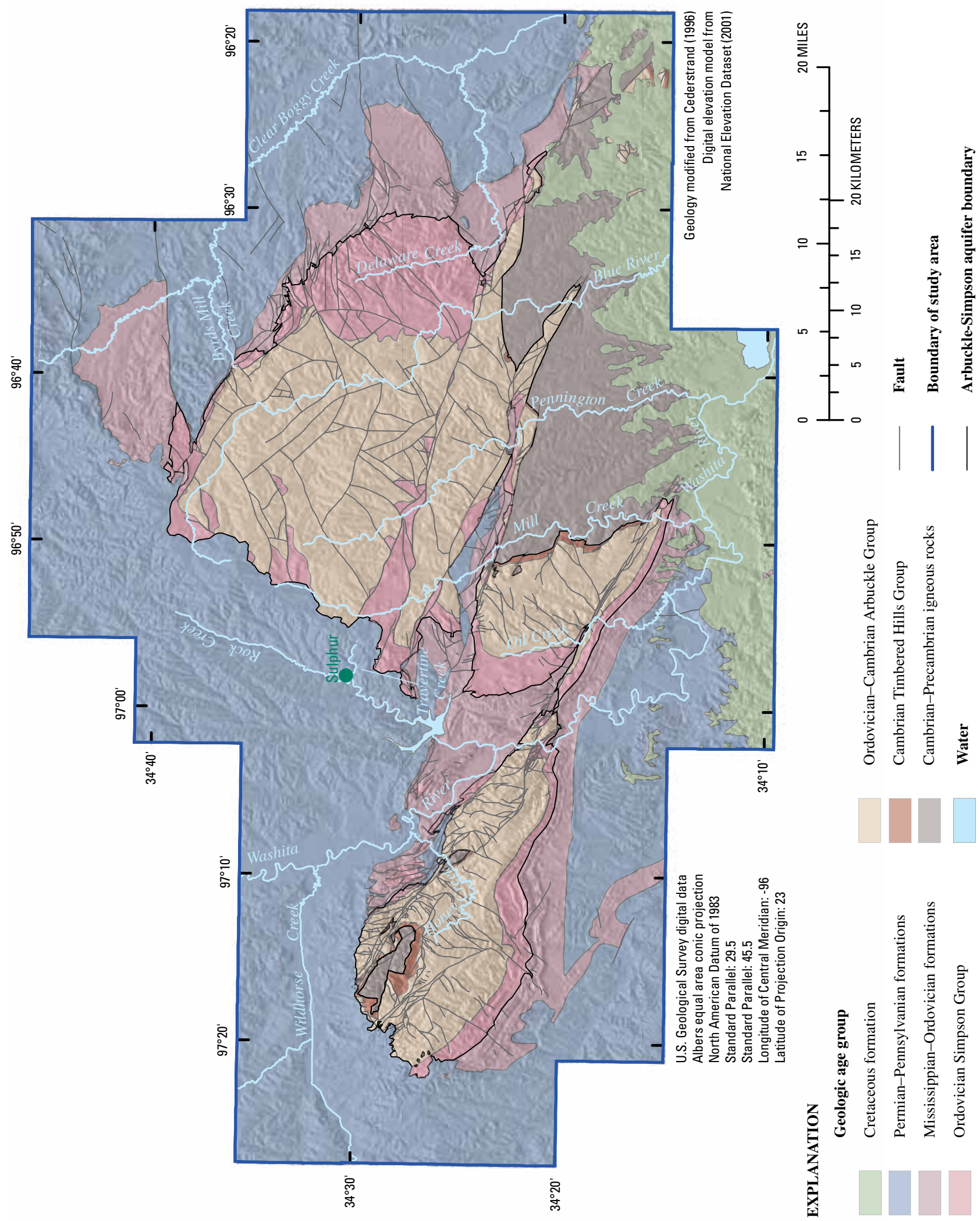

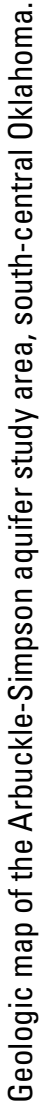


rocks in Oklahoma. A test well drilled as part of this investigation encountered voids with red-clay and calcite fillings, which are consistent with karst features at depth.

\section{Hydrology}

The hydrology of the Arbuckle-Simpson aquifer has been described in numerous publications, including Fairchild, Hanson, and Davis (1990), Hanson and Cates (1994), Savoca and Bergman (1994), Andrews and Burrough (2002), and Harp and McLin (1986). The description of the hydrology of the Arbuckle-Simpson aquifer included in this report is information needed to understand the geochemistry and water quality of the aquifer, which are the subjects of this report.

\section{Climate}

The study area is considered to have a moist, sub-humid climate (Fairchild, Hanson, and Davis, 1990). Mean annual precipitation, based on data from 1971 to 2000 at Ada, Oklahoma, is 41.26 inches (National Climatic Data Center, 2008). Monthly average precipitation for Ada is shown in table 1. Monthly average temperatures for Ada are shown in table 2. Annual potential evapotranspiration is about equal to annual precipitation. Koren and others (1998) calculated annual potential evaporation at Blue River near Blue, Oklahoma, about 30 miles southeast of the aquifer, to be 44.11 inches. Annual pan evaporation averaged 49.38 inches at Atoka, about 20 miles east of the aquifer, and 55.78 inches at Chickasha,

Table 1. Monthly and annual average precipitation at Ada, Oklahoma (1971-2000).

[Data from National Climatic Data Center (2006)]

\begin{tabular}{lc}
\hline Month & $\begin{array}{c}\text { Average precipitation } \\
\text { (inches) }\end{array}$ \\
\hline January & 1.85 \\
February & 2.19 \\
March & 3.68 \\
April & 3.75 \\
May & 5.53 \\
June & 4.53 \\
July & 2.70 \\
August & 3.02 \\
September & 4.57 \\
October & 3.90 \\
November & 3.14 \\
December & 2.40 \\
Annual & 41.26 \\
\hline
\end{tabular}

Table 2. Monthly and annual average temperature at Ada, Oklahoma (1971-2000).

[Data from National Climatic Data Center (2006)]

\begin{tabular}{lccc}
\hline & \multicolumn{3}{c}{$\begin{array}{c}\text { Temperature } \\
\text { (degrees Celsius) }\end{array}$} \\
\cline { 2 - 4 } & $\begin{array}{c}\text { Daily } \\
\text { maximum }\end{array}$ & $\begin{array}{c}\text { Daily } \\
\text { minimum }\end{array}$ & Mean \\
\hline January & 9.9 & -2.4 & 3.8 \\
February & 13.4 & 0.2 & 6.8 \\
March & 18.3 & 4.7 & 11.5 \\
April & 23.0 & 9.1 & 16.1 \\
May & 26.8 & 14.3 & 20.6 \\
June & 30.8 & 18.9 & 24.8 \\
July & 33.8 & 21.5 & 27.7 \\
August & 33.6 & 20.8 & 27.2 \\
September & 29.4 & 16.5 & 22.9 \\
October & 23.9 & 10.4 & 17.2 \\
November & 16.6 & 4.1 & 10.4 \\
December & 11.4 & -0.8 & 5.3 \\
Annual & 22.1 & 9.8 & 16.2 \\
\hline
\end{tabular}

about 30 miles northwest of the aquifer (Farnsworth and Thompson, 1982). Fairchild, Hanson, and Davis (1990) estimated actual evapotranspiration for the study area to be about 31 inches per year, or about 80 percent of precipitation (based on data from 1969-71 and 1976-79).

\section{Surface Water}

Perennial streams that originate in the Arbuckle-Simpson aquifer include Blue River, Byrds Mill Creek, Delaware Creek, Honey Creek, Mill Creek, Pennington Creek, Oil Creek, Rock Creek, and Travertine Creek (fig. 4). Blue River, which drains a large part of the Hunton Anticline, is the largest stream that originates within the study area. The drainage basin for Rock Creek near Sulphur is partially on the Arbuckle-Simpson aquifer. The Washita River flows across the aquifer and a small part of its drainage basin is on the outcrop of the Arbuckle-Simpson aquifer. The Washita River may receive some ground-water discharge from the aquifer, but the discharge of the Washita River is large and the river is in contact with the aquifer for only a short distance. No measurements were made as part of this study that might show if ground water originating in the Arbuckle-Simpson aquifer is discharging to the river.

Many springs discharge from the Arbuckle-Simpson aquifer. The U.S. Geological Survey's National Water Information System database lists 140 springs in the study area (fig. 5). Many of the springs are located near the boundary 

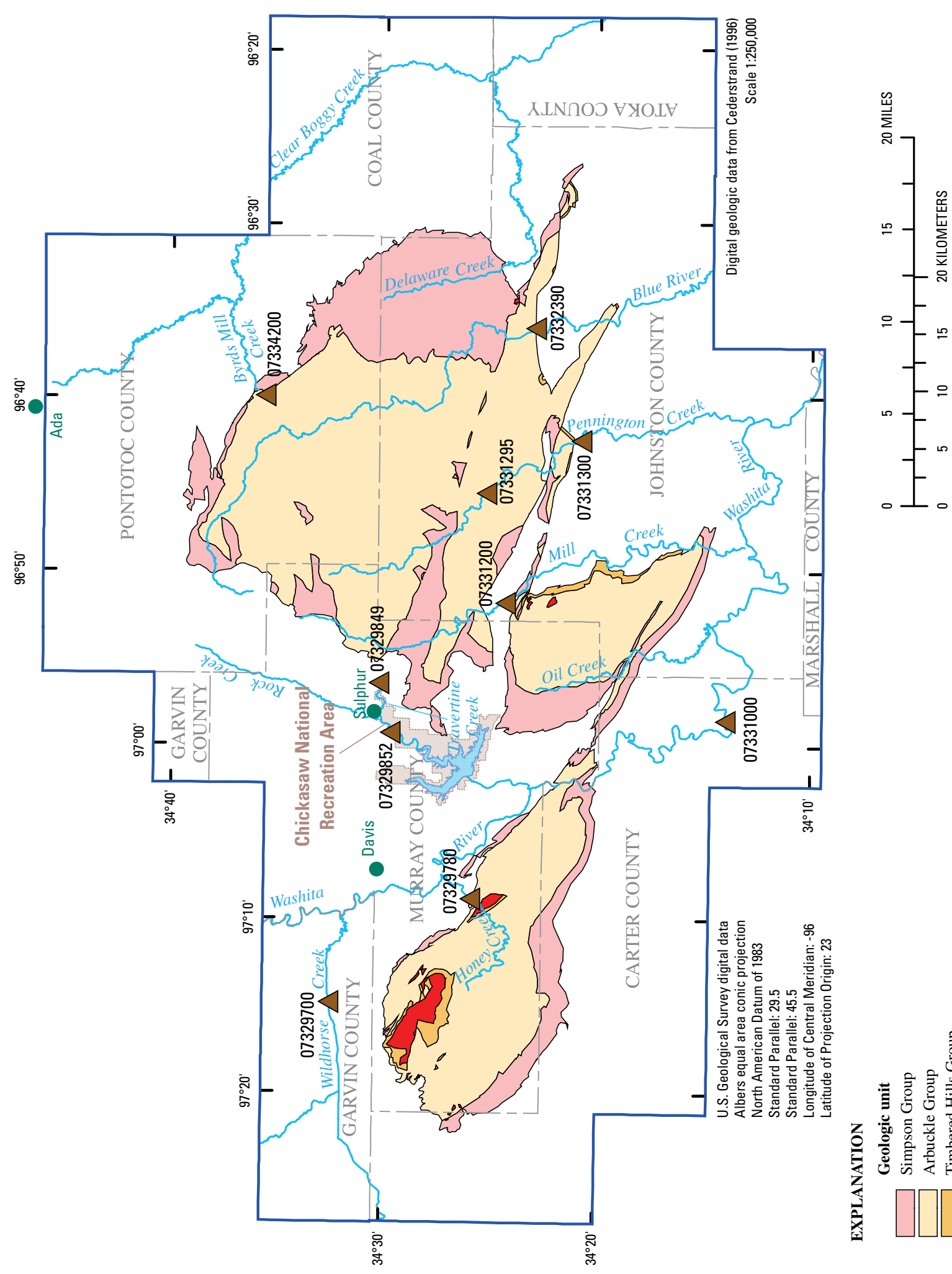

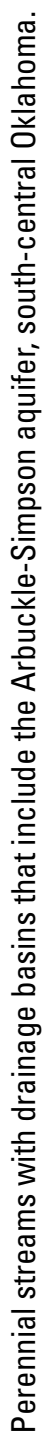



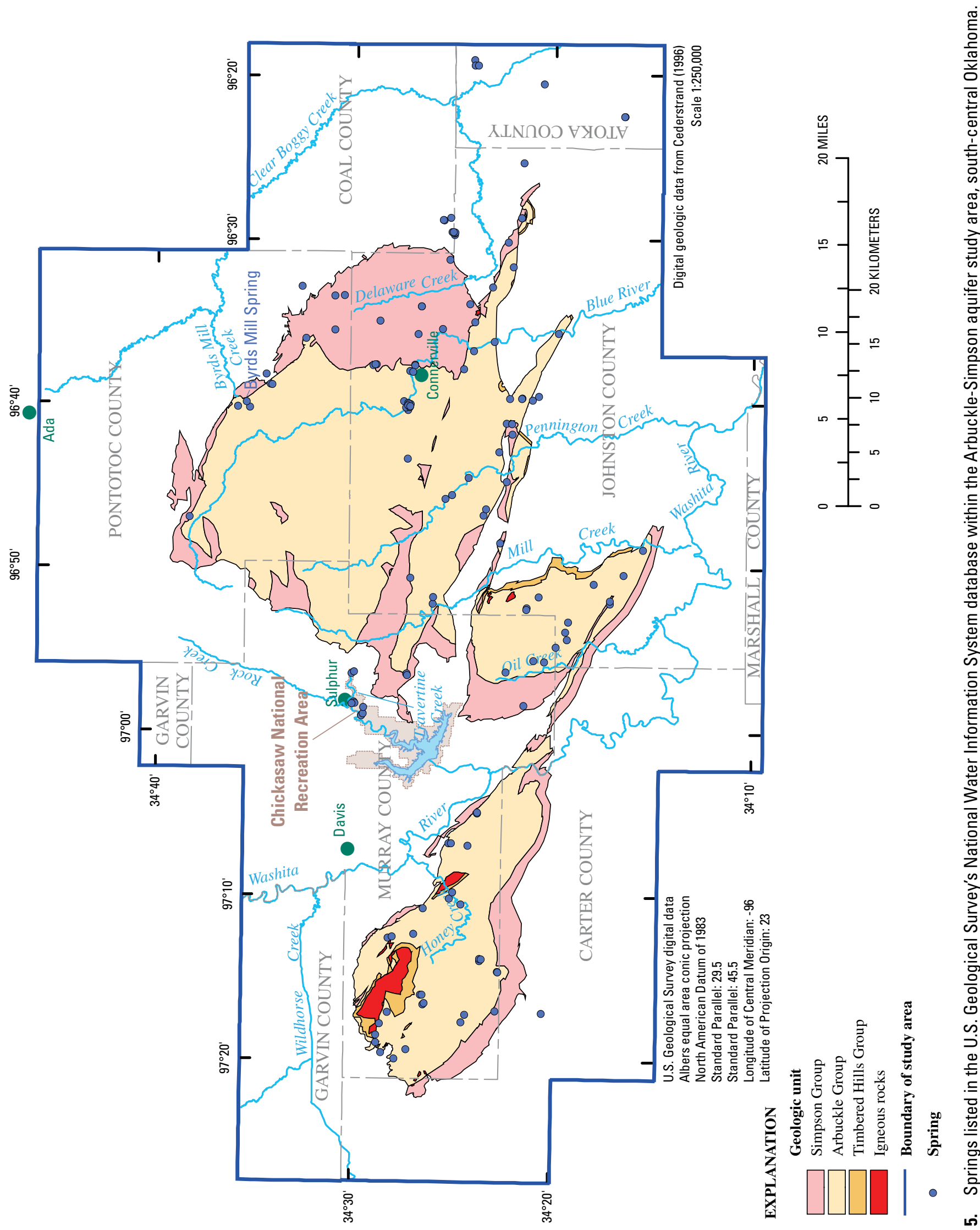
of the aquifer outcrop. A large group of springs is located on Blue River west of Connerville, and these springs are not located near the outer boundary of the aquifer. Another group of springs is found in the Chickasaw National Recreation Area near Sulphur outside of the outcrop of the aquifer. Freshwater and mineralized springs are found within and near the Chickasaw National Recreation Area. The origin of the water flowing to the springs in the Chickasaw National Recreation Area is discussed in more detail in this report. Byrds Mill Spring, with an average annual discharge (based on a period of record from 1990 to 2005) of 18.6 cubic feet per second, is the largest spring in Oklahoma and serves as the primary water supply for the City of Ada. During most years, discharge from springs maintains flow in the larger streams in the study area in the absence of rainfall.

Fairchild, Hanson, and Davis (1990) estimated that during the time of their investigation (1976-79) evapotranspiration accounted for 80 percent of the annual precipitation. They estimated that the remaining 20 percent of precipitation discharges from the study area as surface water and includes 4.7 inches per year base flow and 2.9 inches per year direct runoff.

\section{Ground Water}

The primary source of water in the aquifer is diffuse recharge from precipitation, estimated by Fairchild, Hanson, and Davis (1990) to be about 4.7 inches per year in the Hunton Anticline in the late 1970s. Ground-water flow in the Hunton Anticline generally is to the southeast. The potentiometric surface calculated from head measurements obtained at wells, springs, and streams is shown in figure 6. Ground water discharges to streams and springs, with the largest discharges in the downgradient part of the aquifer. Limited potentiometric data in the Arbuckle and Tishomingo Anticlines show generally radial flow patterns (Fairchild, Hanson, and Davis, 1990). As in the Hunton Anticline, ground water in the Arbuckle and Tishomingo Anticlines discharges to streams and springs. The depth of fresh ground water within the outcrop area is not known but a small number of wells exceed 1,000 feet in depth and do not encounter saline water. A test well completed as part of this investigation was drilled to a depth of 1,820 feet and produced freshwater.

The freshwater zone of the aquifer generally coincides with the outcrop area of the aquifer. Freshwater extends beyond the outcrop in several locations; the most notable is located near the town of Sulphur and the Chickasaw National Recreation Area. Ground water flows west from the Hunton Anticline and becomes confined beneath Pennsylvanian-age cemented conglomerates. Ground water discharges to springs, Travertine and Rock Creeks, and wells, some of which are flowing (artesian) wells. A few wells produce freshwater from the Arbuckle-Simpson aquifer just west of Rock Creek, west of Sulphur, indicating freshwater circulates at least that far to the west. Springs in the Chickasaw National Recreation Area become increasingly saline from east to west, indicating the presence of a freshwater-saline water transition zone. The zone where freshwater circulation is inferred west of the outcrop of the Hunton Anticline is shown in figure 6 as "Post-Simpson group." The extent of the freshwater zone is inferred from the locations of wells that produce water from the ArbuckleSimpson aquifer beneath the post-Simpson group, but the precise extent of the freshwater zone is not known. The geohydrology of the area surrounding Chickasaw National Recreation Area has been described in numerous publications, including Andrews and Burrough (2002), Hanson and Cates (1994), and Harp and McLin (1986).

Another location where relatively freshwater extends beyond the aquifer outcrop is at approximately $34^{\circ} 44^{\prime}$ north 96 43' west (North American Datum of 1927 [NAD27]). An old drilling report on file at the U.S. Geological Survey Oklahoma Water Science Center indicates that at that location a 1,967-foot deep industrial well, which was plugged back to 1,865 feet, produced water in 1954 in which total dissolved solids ranged from 672 to 2,226 parts per million. Although the geologic unit in which the well is completed is not specified in the data on file for this well, the description of the cuttings from the drilling log makes it likely the well is completed in the Arbuckle or Simpson Groups.

One well within the aquifer outcrop in the eastern part of the Hunton Anticline is known to produce water with higher dissolved solids than typical of water within the outcrop (typical water chemistry is discussed in the "Descriptive Water Quality" section of this report). The well, site 6 in figures 7 and 8 and appendix 1, is 1,400 feet deep. On October 21, 2004 , the specific conductance of water from this well was 1,350 microsiemens per centimeter $(\mu \mathrm{S} / \mathrm{cm})$ and the dissolved solids were 768 milligrams per liter $(\mathrm{mg} / \mathrm{L})$, which is the most saline water that was sampled within the aquifer outcrop as part of this investigation. No other deep water wells are known in this part of the aquifer, but this single well indicates that salinity probably increases with depth within the aquifer outcrop area.

Beyond the outcrop area of the aquifer, the Arbuckle and Simpson Groups are major producers of oil and gas. Oil and gas fields are located near the boundary of the aquifer. Boyd (2002) shows oil and gas fields in contact with the aquifer at the northern extent of the Arbuckle Anticline at approximately $34^{\circ} 30^{\prime}$ north latitude, $97^{\circ} 10^{\prime}$ west longitude (North American Datum of 1983 [NAD83]) and at the northern extent of the Hunton Anticline at approximately $34^{\circ} 38^{\prime}$ north latitude, $96^{\circ} 40^{\prime}$ west longitude (NAD83). Wells in the Chickasaw National Recreation area, known as the East (approximately $34^{\circ} 30^{\prime}$ north latitude, $96^{\circ} 56^{\prime}$ west longitude, NAD27) and West (approximately $34^{\circ} 30^{\prime}$ north latitude, $96^{\circ} 57^{\prime}$ west longitude, NAD27) Observation Wells, produce small amounts of asphalt (Hanson and Cates, 1994). In an area about 3 miles south of Sulphur, sandstone within the Oil Creek Formation contains about 8 percent asphalt and was mined for roadsurfacing material from 1890 until 1962 (Ham, 1973).

Ground water in the Arbuckle-Simpson aquifer moves through porous media, solution-enlarged conduits, and 

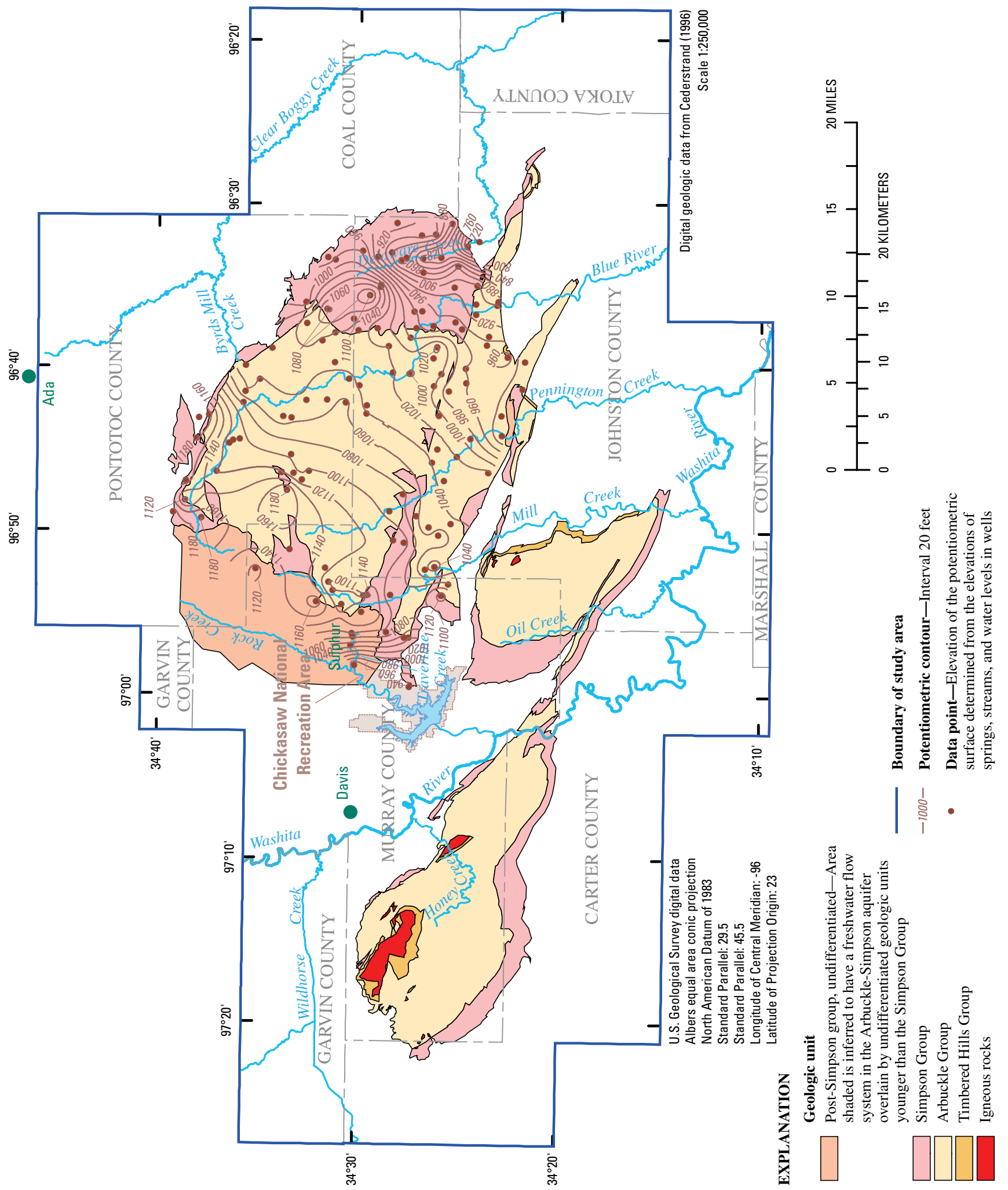

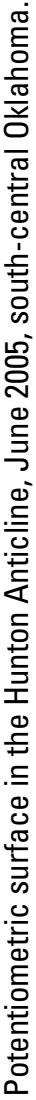



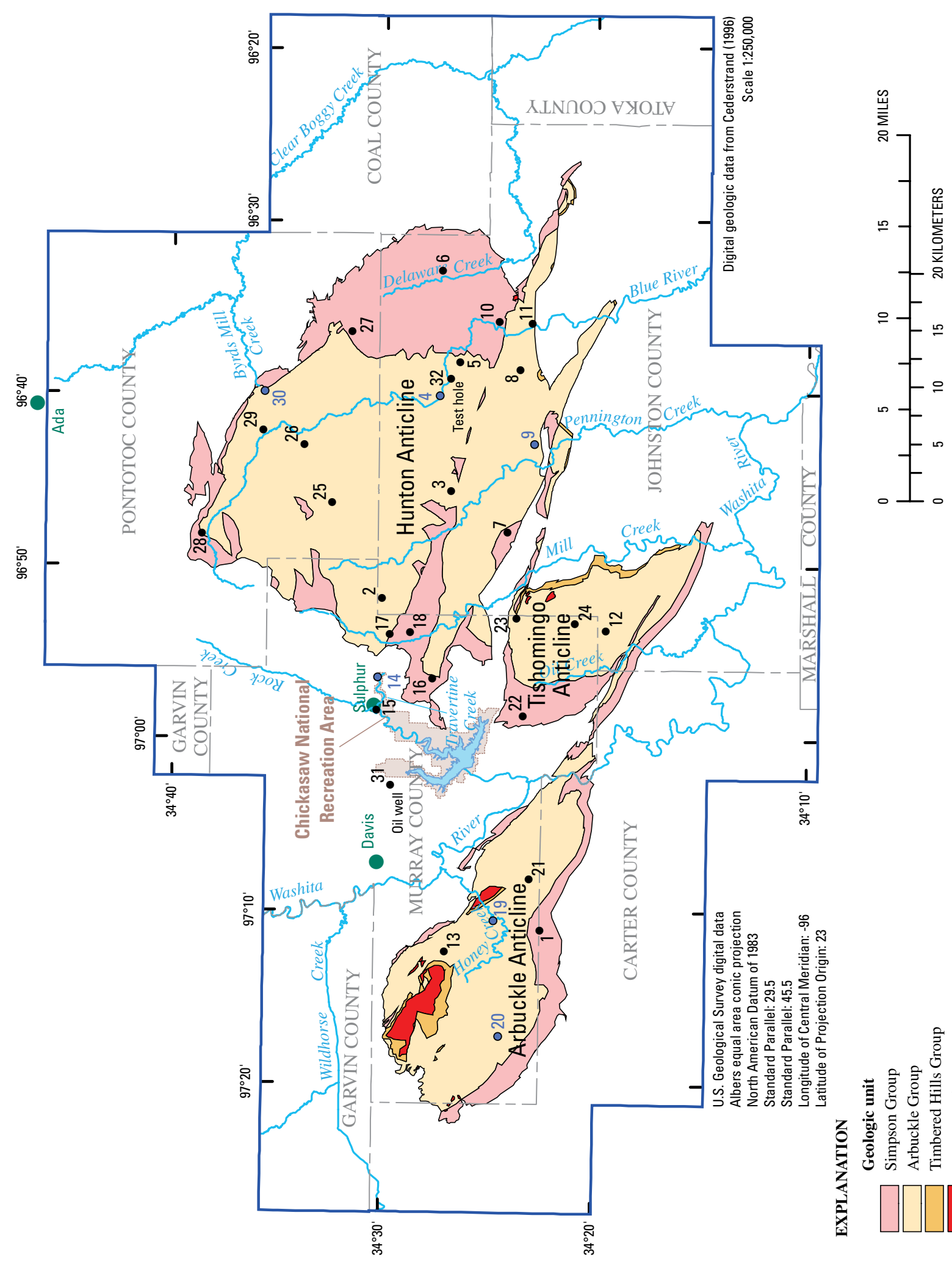

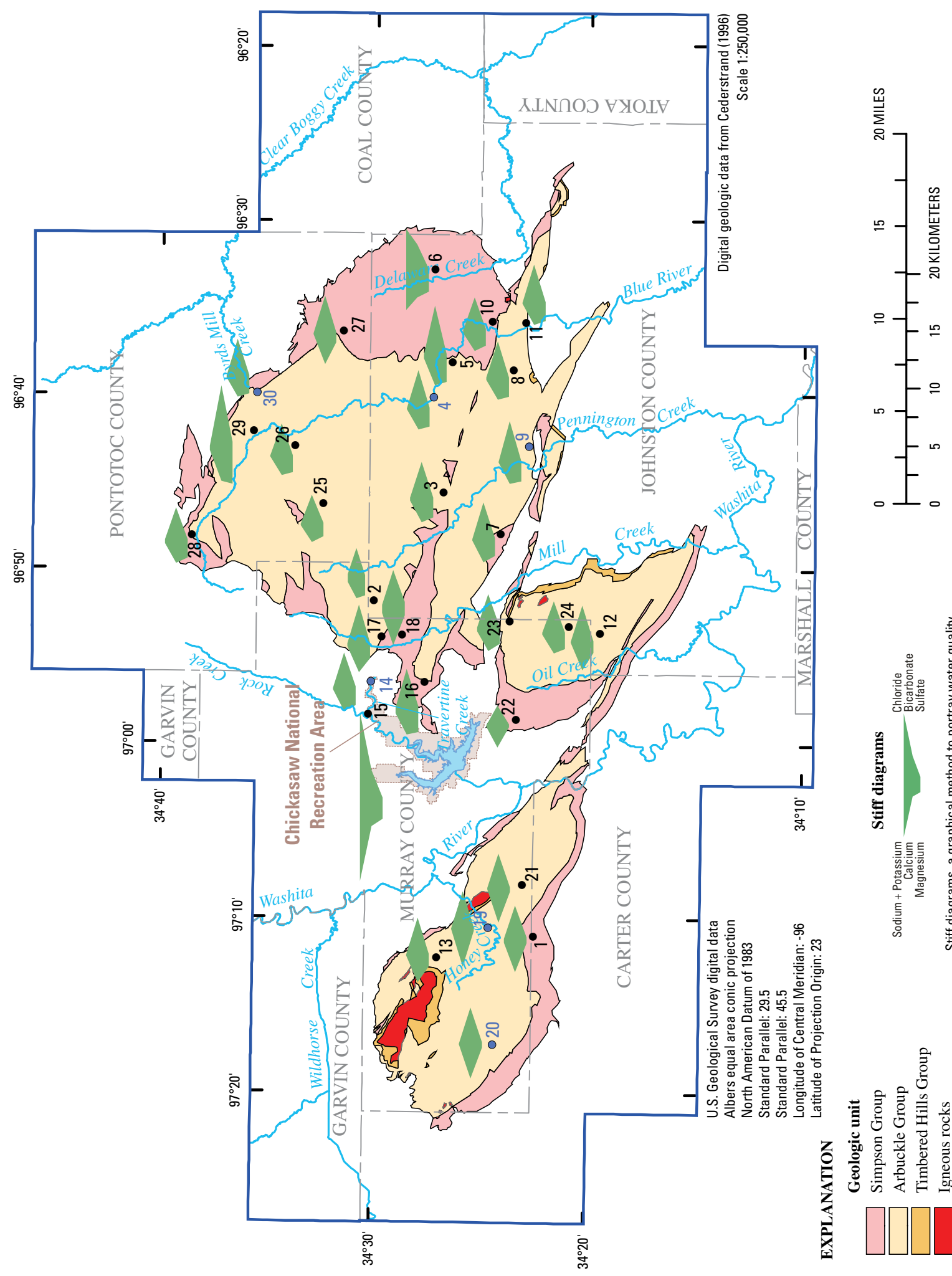

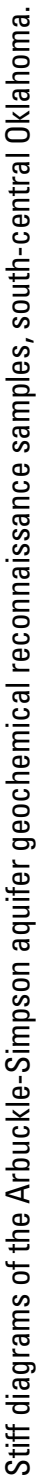


fractures. The sandstone units within the Simpson Group, where they are exposed at the land surface, appear to be porous media that would allow substantial ground-water flow. Several human-enterable caves in the study area contain streams, and the presence of paleokarst at depth in the aquifer makes it likely that some fraction of the ground-water flow in the aquifer is moving in conduits. Electrical resistivity imaging as part of the current study documented the presence of epikarst developed at some locations in the aquifer (T. Halihan, Oklahoma State University, written commun., 2004), which may enhance ground-water flow.

The Arbuckle-Simpson aquifer contains many fractures that are likely pathways for ground-water movement. Many voids were encountered in a test well drilled during this investigation, and some of these voids produced large quantities of water (total production from this test well was estimated to be 1,000 gallons per minute). Subsequent testing of the test well by using packers to isolate intervals revealed that not all fractures produce substantial quantities of water.

Both the Arbuckle and Simpson Groups yield substantial quantities of water to wells and thus are considered to be aquifers. However, a number of observations indicate that, at least in the eastern part of the Hunton Anticline, the Simpson Group is acting as a confining layer. These indications are (1) the presence of at least one flowing well, (2) a group of springs on Blue River that occurs at a location immediately before the Blue River flows across the Simpson Group (fig. 5), and (3) the hydraulic gradients on the potentiometric map in Fairchild, Hanson, and Davis (1990, plate 2) that are considerably steeper in the Simpson Group than in the adjacent Arbuckle Group. The Simpson Group includes sequences of sandstones, shales, and limestones that appear to conduct water horizontally, thus yielding water to wells, but are less conductive vertically.

Fairchild, Hanson, and Davis (1990) determined the hydraulic properties of the Arbuckle-Simpson aquifer by using a combination of aquifer tests and regional techniques that use streamflow and water-level hydrographs. They estimated the average transmissivity of the aquifer to be 15,000 feet squared per day and the storage coefficient to be 0.008 (unitless).

\section{Geochemical Investigation}

A geochemical reconnaissance investigation of the Arbuckle-Simpson aquifer was initiated in 2004 to characterize the ground-water quality at an aquifer scale, describe the chemical evolution of ground water as it flows from recharge areas to discharge in wells and springs, and determine the residence time of ground water in the aquifer. Characterization of aquifer-scale ground-water quality was accomplished by (1) collecting 36 water samples from 32 wells and springs distributed across the aquifer for chemical analysis of major ions, trace elements, isotopes of oxygen and hydrogen, dissolved gases, and age-dating tracers; and (2) calculating descriptive statistics by using the results of the chemical analyses of the water samples. The chemical analyses also were used as input to geochemical models to evaluate the chemical evolution of the water as it moves through the aquifer. Age-dating tracers were used to determine the approximate time of recharge and residence time of ground water in the aquifer.

\section{Methods}

The study design of the Arbuckle-Simpson Hydrology Study relied on collecting ground-water and spring samples for analysis for a wide variety of analytes. The selection of sampling sites and the purpose of different kinds of samples are described in the "Study Design" section. The actual sampling process and analytical methods are described in the "Field-Sampling Protocols and Analytical Methods" section. Finally, efforts to assess sample contamination and reproducibility are described in the "Quality-Assurance Samples" section.

\section{Study Design}

The sampling of Arbuckle-Simpson aquifer wells and springs consisted of two parts, geochemical reconnaissance sampling and targeted sampling. The purpose of the geochemical reconnaissance sampling was to collect water samples (1) that could be used to describe the shallow groundwater quality of the Arbuckle-Simpson aquifer, (2) for input to geochemical models to evaluate the chemical evolution of the water as it moves through the aquifer, (3) to analyze for age-dating tracers to determine the approximate time of recharge and residence time of ground water in the aquifer, and (4) to guide additional sampling efforts. A small number of additional targeted samples were collected after the initial reconnaissance to take advantage of sampling opportunities or to investigate specific research topics.

For the geochemical reconnaissance, ground- and springwater samples were collected from 24 wells and 5 springs during October and November 2004. The wells and springs included in the reconnaissance were selected to obtain broad coverage of the study area, including the Arbuckle, Tishomingo, and Hunton Anticlines. Shallow wells were selected (less than 500 feet deep) because most deep wells in this aquifer are completed with long open intervals and produce water from many zones. The suite of analytes for most samples included major ions, trace elements, nutrients, oxygen and hydrogen isotopes, chlorofluorocarbons (CFCs), dissolved gases, and tritium (table 3). Six wells and springs that were suspected to intercept long ground-water flow paths were sampled for analysis of carbon-14 and carbon-13/carbon-12 ratio.

After the initial sampling of 24 wells and 5 springs, Byrds Mill Spring was sampled because it drains most of the northeastern part of the Hunton Anticline and is the major source of water for the City of Ada. The City of Ada granted permission to sample the spring and samples were 
Table 3. Analytes and schedules for Arbuckle-Simpson geochemical sampling.

[USGS, U.S. Geological Survey; *, not collected for all samples]

\begin{tabular}{|c|c|}
\hline Major ions (USGS schedule 934) & Nutrients (USGS schedule 101) \\
\hline Boron & Nitrogen, ammonia \\
\hline Bromide & Nitrogen, nitrite \\
\hline Calcium & Nitrogen, nitrite + nitrate \\
\hline Chloride & Phosphorous, orthophosphate \\
\hline \multicolumn{2}{|l|}{ Fluoride } \\
\hline Iodide & Oxygen/hydrogen isotopes (USGS schedule 1142) \\
\hline Magnesium & Deuterium/protium ratio \\
\hline Potassium & Oxygen-18/oxygen-16 ratio \\
\hline \multicolumn{2}{|l|}{ Residue (total dissolved solids) } \\
\hline Silica & Chlorofluorocarbons* \\
\hline Sodium & Chlorofluorocarbon-11 \\
\hline \multirow[t]{2}{*}{ Sulfate } & Chlorofluorocarbon-12 \\
\hline & Chlorofluorocarbon-113 \\
\hline \multicolumn{2}{|l|}{ Trace elements (USGS schedule 1673) } \\
\hline Aluminum & Carbon-14 suite* \\
\hline Antimony & Carbon-14 \\
\hline Arsenic & Carbon-13/carbon-12 \\
\hline \multicolumn{2}{|l|}{ Barium } \\
\hline Beryllium & Tritium/dissolved gases \\
\hline Cadmium & Argon \\
\hline Chromium & Helium \\
\hline Cobalt & Krypton \\
\hline Copper & Methane \\
\hline Iron & Nitrogen/argon ratio \\
\hline Lead & Oxygen \\
\hline Lithium & Xenon \\
\hline Manganese & Argon-40/argon-36 ratio \\
\hline Molybdenum & Neon-20/neon-22 ratio \\
\hline Nickel & Nitrogen/argon ratio \\
\hline Selenium & Tritium by helium-3 ingrowth \\
\hline \multicolumn{2}{|l|}{ Silver } \\
\hline \multicolumn{2}{|l|}{ Strontium } \\
\hline \multicolumn{2}{|l|}{ Thallium } \\
\hline \multicolumn{2}{|l|}{ Uranium, natural } \\
\hline \multicolumn{2}{|l|}{ Vanadium } \\
\hline Zinc & \\
\hline
\end{tabular}

collected in November 2005. The chemical analysis of the water sample from Byrds Mill Spring is included in the regional-scale analysis of water-chemistry data in this report. Thus, a total of 24 wells and 6 springs are included in the Arbuckle-Simpson geochemical reconnaissance. The results of the chemical analyses for these 30 sites are included in appendix 1 and are labeled as sites 1 through 30 .

After completion of the geochemical reconnaissance, additional samples, referred to as "targeted samples," were collected from wells to address two specific issues. One of the specific issues was an interest in the chemistry and flow system for the mineralized springs of the Chickasaw National
Recreation Area. Water discharging from the springs was hypothesized to be a mixture of freshwater from the ArbuckleSimpson aquifer and brines that surround the aquifer. A sample of brine was collected from an oil well (site 31 in figure 7 and appendix 1) that is about 3 miles west of Chickasaw National Recreation Area and produces fluids from the Oil Creek Formation of the Simpson Group. The same suite of chemical constituents was analyzed for the oil well sample as the 30 reconnaissance samples, including carbon-14 and carbon-13/carbon-12 ratio, although samples for noble gases and tritium were not collected. The chemical analysis of the water sample from the oil well (sample 31 in appendix 1) 
is not included in regional-scale analysis of water-chemistry data of the Arbuckle-Simpson aquifer because the water from this well is not part of the freshwater flow system in the Arbuckle-Simpson aquifer. For example, the data from this sample were not used in calculating percentiles in the "Descriptive Water Quality" section of this report.

Another specific issue about the geochemistry of the Arbuckle-Simpson aquifer was the depth to which freshwater circulates within the aquifer. The few wells drilled in the study area for maximum production, such as the wells belonging to the cities of Ada and Sulphur, produced sufficient water by drilling to about 1,000 feet. Because there are no producing oil or gas wells within the outcrop of the aquifer, no information about the depth of freshwater is available from oil and gas wells. Limited water-chemistry data from a single well near the center of the Hunton Anticline (approximate location $34^{\circ} 31^{\prime}$ north, $96^{\circ} 46^{\prime}$ west, NAD27) is documented in

Fairchild, Hanson, and Davis (1990). These data show freshwater at a depth of 2,500 feet, although there is little information about the methods employed to collect the sample, which may represent a composite sample from a long open borehole, including shallow freshwater zones.

Two test wells were drilled as part of the current study to collect high-quality water samples at depth from the Arbuckle-Simpson aquifer. The initial goal of the drilling was to drill to the granitic basement rocks or until saline water was encountered. The plan was to drill with compressed air and an air-hammer bit until the air could no longer remove cuttings from the test well, then switch to air or hydraulic rotary methods. Large voids that produced large quantities of water were encountered during drilling, which caused the air hammer not to function correctly. The first test well was abandoned at a depth of 628 feet because of excess water, and a second test well was started about 160 feet from the first well with larger diameter air-hammer bits. Large volumes of water once again caused problems with the air-hammer drilling that necessitated a switch from the relatively rapid air-hammer process to a much slower air-rotary process. The available funding for the drilling effort was expended before the target was reached, and drilling ceased at a depth of 1,820 feet. The rock in the test well was competent, and the borehole was left uncased below a 35-foot length surface casing.

Water samples were collected during drilling from the second, deeper test well (site 32 in figure 7 and appendix 1). The selection of the sampled intervals was made on the basis of drilling conditions (such as reports of fractures by the driller), drill cuttings, and the amount of water produced. Five water samples were collected by removing the drill pipe and bit and inserting a single packer on the drill pipe to isolate the lowermost zone of the drill hole. However, drilling foam was used during drilling, and even after purging the well overnight the produced water still contained drilling foam, which indicated that the samples were contaminated with air from the drilling process. Thus, the samples were not analyzed for the planned comprehensive suite of analytes. Specific conductance in water from the shallowest zone (an open borehole drilled to 120 feet) was $595 \mu \mathrm{S} / \mathrm{cm}$. Specific conductance from the deepest zone (a single packer set at 1,282 feet, so the sampled zone was 1,282 to 1,820 feet) was identical, $595 \mu \mathrm{S} / \mathrm{cm}$. Major cations and anions were analyzed at Oklahoma State University (T. Halihan, Oklahoma State University, written commun., 2006) for samples collected at the time of drilling. Remarkably little variation in water chemistry was found between the deepest and shallowest samples.

The test well was left undisturbed for 9 months after the initial drilling process to dissipate the air and foam introduced by the drilling process, and then the test well was sampled by using a combination of single and double (straddle) packers. Five distinct zones were sampled at different depths to create a geochemical profile. Unfortunately the test well partially collapsed during the 9-month period, and a blockage was encountered at a depth of 1,604 feet. The deepest zone was sampled with a single packer set on a smooth section of borehole at a depth of 1,492 feet and the drill hole was pumped from below that depth. The same analytes were collected for the five zones as for the reconnaissance samples except no samples were collected for carbon-14 or the carbon-13/carbon-12 ratio.

None of the chemical analyses of the water samples from the test well are included in the regional-scale water-chemistry data of the Arbuckle-Simpson aquifer, because the analyses would tend to bias the regional-scale data toward a single point and because the samples were collected from an entirely different type of well with different downhole equipment from all other well samples. The results of the chemical analyses for the test hole are included in appendix 1 and are listed as site 32, samples 32 through 36.

\section{Field-Sampling Protocols and Analytical Methods}

All water samples were collected by using standardized U.S. Geological Survey protocols (Wilde and others, 1998). Most sampled wells were domestic wells in daily use and equipped with submersible pumps. The protocol for sampling the well was to connect the sampling manifold to a fitting as close as possible to the well head by using a garden-hose connector. The sampling manifold consisted of a plastic gardenhose connector attached to clear Tygon tubing, which was connected to several splitters and valves to control flow. One flow line discharged to waste, one flow line was connected to a flow-through cell, and one flow line was used for sampling. For springs and flowing wells (which were not equipped with pumps), an additional sampling line was used. This additional sampling line consisted of a short length of pre-cleaned stainless steel tubing that was connected to a small length of Tygon tubing, which in turn was connected to the inlet of the sampling manifold. A peristaltic pump was used to pump water from the spring or flowing well into the sampling manifold.

Prior to sampling, field measurements of specific conductance, $\mathrm{pH}$, temperature, and dissolved oxygen were made with a calibrated multiprobe in a sealed flow-through cell. The 
wells were pumped to remove at least three casing volumes of water prior to any field measurements. Specific conductance, $\mathrm{pH}$, temperature, and dissolved oxygen were measured at 5-minute intervals until the chemistry of the discharge water stabilized. The stability criteria used were (1) less than 10 -percent variation in specific conductance; (2) less than 0.1 -unit variation in $\mathrm{pH}$; (3) less than 0.5 -degree Celsius variation in temperature; and (4) less than $0.3-\mathrm{mg} / \mathrm{L}$ variation in dissolved oxygen. After the stability criteria were met, water was diverted to an enclosed sampling chamber to prevent contamination during sampling.

Major ion, trace element, nutrient, carbon-14, and carbon-13/carbon-12 ratio samples were filtered by using a 0.45 -micrometer pore-size disposable capsule filter. The filtered samples for dissolved cations and trace elements were acidified to a $\mathrm{pH}$ less than 2 with trace-element-grade nitric acid. Samples for CFCs were not filtered; samples were collected in borosilicate glass bottles and sealed with metal foil seals while submerged in a metal, water-filled bucket. Nutrient samples were filtered with a 0.45 -micrometer pore-size disposable capsule filter, collected in opaque brown polyethylene bottles, chilled to 4 degrees Celsius, and sent by overnight courier to arrive at the U.S. Geological Survey's National Water Quality Laboratory within 48 hours of sample collection. Samples for tritium were collected in polyethylene bottles and sealed with polycone caps. Samples for dissolved gases were collected in copper tubes pinched with refrigeration clamps. Samples for carbon-14 and carbon-13/carbon-12 ratio were filtered through a 0.45 -micrometer pore-size disposable capsule filter and collected in a glass bottle underwater. Samples for tritium and oxygen and hydrogen isotopes were not filtered; samples were collected in glass bottles and sealed with polycone caps.

Decontamination was done by pumping and circulating a 0.1-percent solution of laboratory soap through the tubing and manifold for 10 minutes. About 3 gallons of deionized water were then pumped through the sampling manifold and tubing to rinse any residual soap or mineralized water; the sampling manifold and tubing were then stored in clean plastic bags (Wilde and others, 1998).

Alkalinity was measured in the field immediately after sampling by using an incremental titration with 0.16-normal standardized sulfuric acid past the bicarbonate-carbonic acid inflection point (about $\mathrm{pH} 4.5$ ). The titration was done in duplicate or until agreement within 2 percent was achieved.

Several laboratories and schedules of analytes were used (table 3) for the geochemical assessment of the ArbuckleSimpson aquifer. All major ion, trace element, and nutrient samples were sent to the U.S. Geological Survey's National Water Quality Laboratory (Fishman, 1993). Oxygen/hydrogen isotope samples were sent to the U.S. Geological Survey's Reston Stable Isotope Laboratory in Reston, Virginia (Coplen, Wildman, and Chen, 1991; Epstein and Mayeda, 1953). CFC samples were sent to the U.S. Geological Survey's Chlorofluorocarbon Laboratory in Reston, Virginia (Busenberg and others, 2006). The Environmental Isotope Laboratory at the
University of Waterloo in Ontario, Canada analyzed carbon-14 (Stuiver and Polach, 1977) and carbon-13/carbon-12 ratio (McCrea, 1950). Tritium and dissolved gas samples were sent to the U.S. Geological Survey's Noble Gas Laboratory in Denver, Colorado.

\section{Quality-Assurance Samples}

Quality-assurance samples were collected and analyzed to quantify the accuracy, precision, and potential bias of environmental samples. Quality-assurance samples for this study consisted of blanks and a replicate sample.

Blank samples are used to indicate if equipment or field conditions could bias the environmental samples. Two kinds of blank samples were collected during the geochemical investigation, a field blank and an equipment blank. The field blank sample was obtained by pumping high-purity pesticide- and inorganic-grade blank water through the sampling equipment at a field site and was processed in a manner identical to an environmental sample. The field blank was used to determine if the sampling equipment, decontamination, or the field environment could bias the environmental sample. The equipment-blank sample was collected at the end of the reconnaisance sampling, also by pumping highpurity pesticide- and inorganic-grade blank water through the sampling equipment used for environmental samples in the laboratory of the U.S. Geological Survey Oklahoma Water Science Center, eliminating the potential for field contamination. The equipment-blank sample was used to determine if the sampling equipment or decontamination process biased the samples. The field and equipment blanks were analyzed by using the major ion and trace element schedules; the field blank also was analyzed for the nutrient schedule.

The blank samples indicated that contaminants were not introduced in any substantial quantity by the sampling equipment or field conditions. Most constituents were not detected above the laboratory minimum reporting levels, with the following exceptions. Aluminum [26 micrograms per liter $(\mu \mathrm{g} / \mathrm{L})]$, silica $(1.76 \mathrm{mg} / \mathrm{L})$, and sodium $(0.44 \mathrm{mg} / \mathrm{L})$ were detected in the equipment blank. Chloride $(0.11 \mathrm{mg} / \mathrm{L})$, iodide $(0.001 \mathrm{mg} / \mathrm{L})$, and vanadium $(0.1 \mu \mathrm{g} / \mathrm{L})$ were detected in the field blank. The aluminum concentration in the equipment blank was $26 \mu \mathrm{g} / \mathrm{L}$, higher than the aluminum concentration in any environmental sample. Thus, the aluminum data for all environmental samples are suspect. The silica, sodium, and chloride concentrations in the blank samples were less than the lowest concentration in any environmental sample, and the small concentrations of these constituents in the blank samples are not considered to be at a concentration that would require action. Most environmental samples had no detectable iodide or iodide concentrations near the minimum reporting level, thus the presence of iodide in the field blank means the samples with low concentrations of detectable iodide may have been contaminated. A small number of environmental samples had no detectable vanadium or vanadium concentrations close to the laboratory minimum reporting level, and thus 
the presence of vanadium in the field blank means that a small number of samples with low concentrations of vanadium may have been contaminated.

A replicate sample was collected and analyzed at one of the environmental sample sites. The sample was collected sequentially after an environmental sample, without the use of a splitting device, and thus could have been sampling water with a different chemistry than the environmental sample if the chemistry of the sampled well was changing during sampling.

The relative percent difference (RPD) between the concentrations from the two samples was calculated as follows:

$$
R P D=100 \frac{\left|C_{1}-C_{2}\right|}{\left(\frac{C_{1}+C_{2}}{2}\right)},
$$

where

$R P D$ is the relative percent difference,

$C_{1}$ is the constituent concentration in the environmental sample, and

$C_{2}$ is the concentration in the replicate sample.

The results of the calculations of the relative percent difference are shown in table 4.

In general, analyzed concentrations in the replicate sample closely matched concentrations in the environmental sample. Only 6 of 43 constituents exceeded a RPD of 5 percent. For the 6 constituents that exceeded a 5 percent $R P D$, all were low concentrations close to the laboratory minimum reporting level. For example, the highest $R P D$ was 66.7 percent for fluoride, but the environmental and replicate sample fluoride concentrations were 0.2 and $0.1 \mathrm{mg} / \mathrm{L}$. Thus, although the relative percent difference is large for these constituents, the difference in concentrations is small. The small RPDs calculated for the replicate sample show that the results for the geochemical reconnaissance are reproducible.

\section{Ground-Water Quality}

\section{Descriptive Water Quality}

A general description of the water quality of the Arbuckle-Simpson aquifer was prepared by (1) comparing the results of the chemical analyses of water samples to waterquality standards, (2) calculating percentiles for concentrations of some of the chemical constituents analyzed in water samples, and (3) determining the chemical water type of the samples.

\section{Percentiles}

Percentiles for each analyte were calculated for the 30 reconnaissance samples. A percentile is a value on the scale of 100 that indicates the percent of a distribution that is equal to or below it. For example, if the 10th percentile of a set of 100 numbers has the value 27 , then 10 percent of the numbers (10 numbers) are less than or equal to 27 ; the median of the set is the 50th percentile. Percentiles are a convenient method to show the distribution of a chemical constituent within a dataset. The percentiles calculated for the Arbuckle-Simpson reconnaissance data are shown in table 5.

Some of the analytical results for the Arbuckle-Simpson water-quality data were censored; that is, the concentration of a chemical constituent was less than the minimum concentration that the laboratory was able to quantify. Some constituents were censored at different concentrations, in which case, all data were censored at the largest censored concentration for calculating percentiles.

Concentrations of analytes were relatively uniform for most constituents in water samples from wells and springs sampled during the Arbuckle-Simpson reconnaissance. For example, the inter-quartile range (data ranging from the 25 th to the 75th percentiles) of dissolved solids ranged only from 331 to $384 \mathrm{mg} / \mathrm{L}$ for the reconnaissance samples. Many waterquality constituents listed in table 5 have small inter-quartile ranges, indicating relatively uniform water composition. Constituents were considered to have small inter-quartile range if the 25 th percentile was greater than or equal to one-half of the 75 th percentile or both the 25 th and 75 th percentiles were censored. Constituents with small inter-quartile ranges include specific conductance, alkalinity, dissolved solids, calcium, magnesium, bicarbonate, carbonate, fluoride, bromide, iodide, silica, nitrite, ammonia, orthophosphate, aluminum, antimony, barium, beryllium, boron, cadmium, chromium, cobalt, iron, molybdenum, silver, and thallium.

The maximum concentration for many constituents came from samples from a single site, site 15 , which is a flowing well known as Vendome Well and is part of the Chickasaw National Recreation Area. Vendome Well is probably the bestknown well in the Arbuckle-Simpson aquifer. The highest concentrations for specific conductance, dissolved solids, sodium, potassium, chloride, fluoride, bromide, iodide, ammonia, arsenic, boron, lithium, selenium, and strontium are from the samples collected from Vendome Well. However, Vendome Well is in the confined part of the aquifer and appears to be at the very edge of the freshwater ground-water flow system and is not representative of water produced from the unconfined part of the aquifer. If Vendome Well had not been sampled as part of the Arbuckle-Simpson geochemical reconnaissance, most of the maximum values in constituent concentrations shown in table 5 would be considerably smaller.

\section{Comparison to Water-Quality Standards}

The chemical analyses from the Arbuckle-Simpson reconnaissance samples were compared to the water-quality standards established by the U.S. Environmental Protection Agency (USEPA) for public water systems. The USEPA establishes a Maximum Contaminant Level (MCL) for some chemical constituents and a Secondary Maximum Contaminant Level (SMCL) for other constituents (USEPA, 2006). 
Table 4. Constituent concentrations and relative percent difference between an environmental sample (site number 29) and a replicate sample.

$\left[\mathrm{mg} / \mathrm{L}\right.$, milligrams per liter; $\mathrm{CaCO}_{3}$, calcium carbonate; $\mathrm{N}$, nitrogen; <, less than; =, one or both concentrations censored, so relative percent difference cannot be calculated, although results are equivalent; P, phosphorus; $\mathrm{E}$, detected analytes with concentrations between long-term method detection level and laboratory reporting level are reported as estimated by the U.S. Geological Survey's National Water Quality Laboratory because a detection in this region should have a $<1$-percent probability of being a false positive (Childress and others, 1999); $\mu \mathrm{g} / \mathrm{L}$, micrograms per liter]

\begin{tabular}{|c|c|c|c|}
\hline Constituent & Environmental sample & Replicate sample & Relative percent difference \\
\hline Alkalinity $\left(\mathrm{mg} / \mathrm{L}\right.$ as $\left.\mathrm{CaCO}_{3}\right)$ & 546 & 550 & 0.7 \\
\hline Dissolved solids (mg/L) & 628 & 632 & .6 \\
\hline Magnesium (mg/L) & 77.5 & 77.3 & .3 \\
\hline Sodium (mg/L) & 7.97 & 8.01 & .5 \\
\hline Carbonate (mg/L) & 0 & 0 & 0 \\
\hline Sulfate (mg/L) & 50.6 & 50.5 & .2 \\
\hline Chloride (mg/L) & 10.8 & 10.8 & 0 \\
\hline Fluoride (mg/L) & .2 & .1 & 66.7 \\
\hline Nitrite plus nitrate (mg/L as $\mathrm{N}$ ) & 2.95 & 3.15 & 6.6 \\
\hline Ammonia (mg/L as N) & $<.04$ & $<.04$ & $=$ \\
\hline Orthophosphate (mg/L as $\mathrm{P})$ & $<.4$ & E.01 & $=$ \\
\hline Aluminum $(\mu \mathrm{g} / \mathrm{L})$ & $<2$ & $<2$ & $=$ \\
\hline Antimony $(\mu \mathrm{g} / \mathrm{L})$ & $<.2$ & $<.2$ & $=$ \\
\hline Arsenic $(\mu \mathrm{g} / \mathrm{L})$ & E.2 & E.2 & 0 \\
\hline Barium $(\mu g / L)$ & 119 & 124 & 4.1 \\
\hline Beryllium ( $\mu \mathrm{g} / \mathrm{L})$ & $<.06$ & $<.06$ & $=$ \\
\hline Boron $(\mu \mathrm{g} / \mathrm{L})$ & 19 & 19 & 0 \\
\hline Lithium $(\mu \mathrm{g} / \mathrm{L})$ & .8 & .9 & 11.8 \\
\hline Manganese ( $\mu \mathrm{g} / \mathrm{L})$ & 3.3 & 3.4 & 3.0 \\
\hline Molybdenum ( $\mu \mathrm{g} / \mathrm{L})$ & $<.4$ & $<.4$ & $=$ \\
\hline Nickel $(\mu \mathrm{g} / \mathrm{L})$ & 2.08 & 2.31 & 10.5 \\
\hline Selenium $(\mu \mathrm{g} / \mathrm{L})$ & E. 4 & .7 & 54.6 \\
\hline Silver $(\mu \mathrm{g} / \mathrm{L})$ & $<.2$ & $<.2$ & $=$ \\
\hline Strontium $(\mu \mathrm{g} / \mathrm{L})$ & 86.4 & 86.5 & .1 \\
\hline Thallium $(\mu \mathrm{g} / \mathrm{L})$ & $<.04$ & $<.04$ & $=$ \\
\hline Vanadium $(\mu \mathrm{g} / \mathrm{L})$ & .8 & .8 & 0 \\
\hline Zinc $(\mu \mathrm{g} / \mathrm{L})$ & 12.0 & 12.1 & .8 \\
\hline Deuterium/protium ratio (permil) & -33.6 & -32.9 & 2.1 \\
\hline Oxygen-18/oxygen-16 ratio (permil) & 5.73 & 5.72 & .2 \\
\hline Uranium $(\mu \mathrm{g} / \mathrm{L})$ & .80 & .82 & 2.5 \\
\hline
\end{tabular}




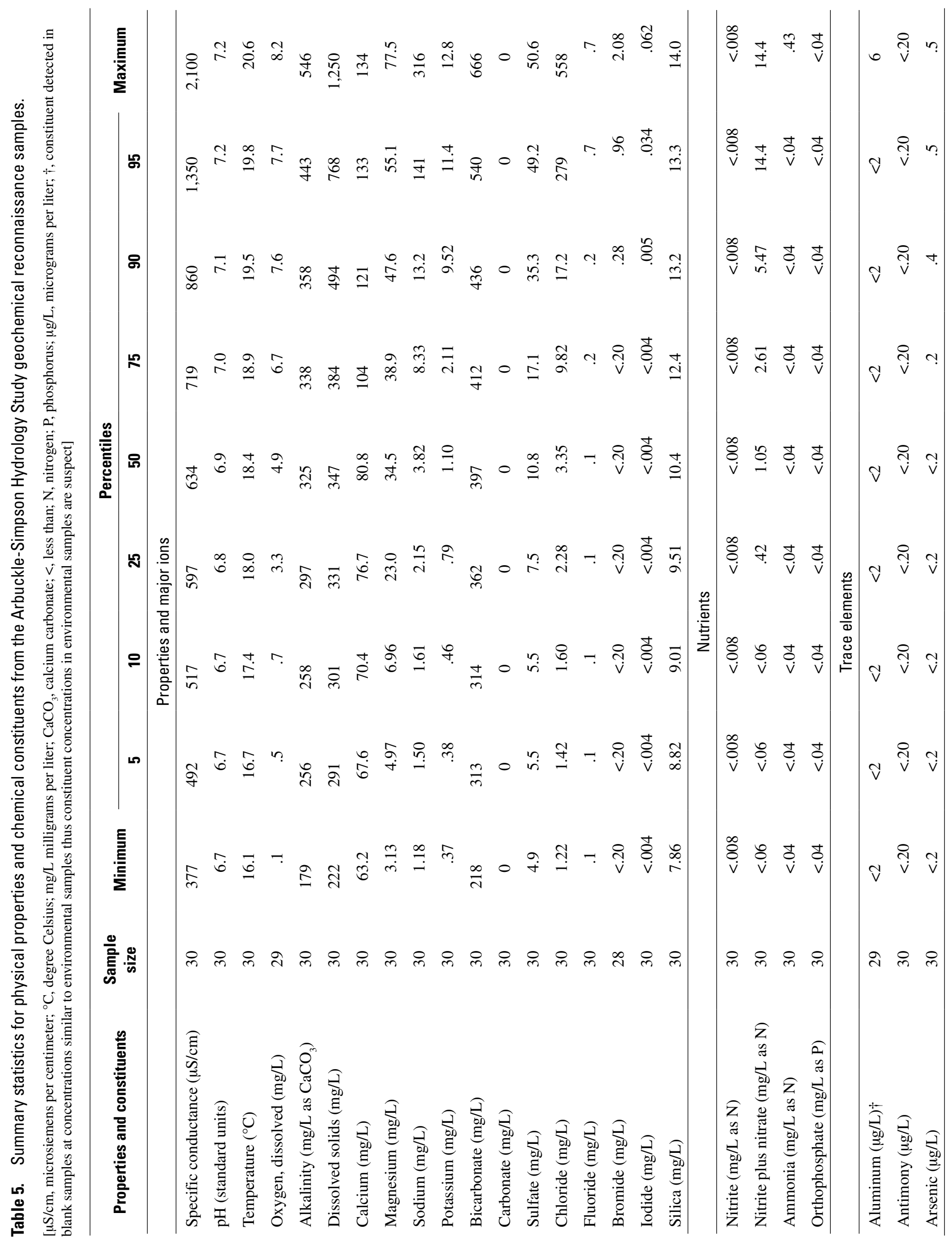




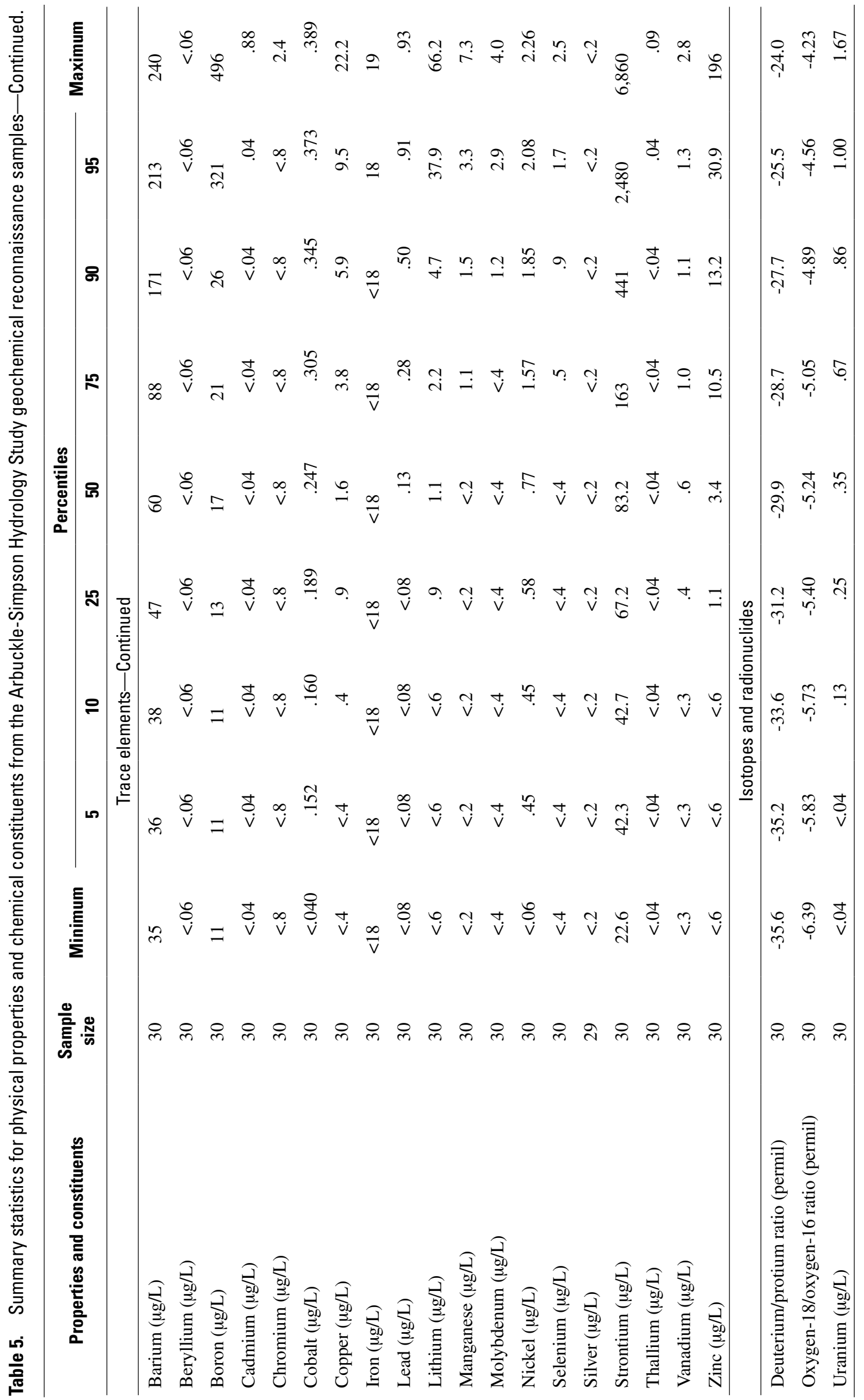


The MCLs are established to protect public health by limiting the levels of contaminants in drinking water (USEPA, 2006). The SMCLs are non-enforceable guidelines regulating contaminants that may cause cosmetic effects (such as skin or tooth discoloration) or aesthetic effects (such as taste, odor, or color) in drinking water. The USEPA recommends secondary standards to water systems but does not require systems to comply (USEPA, 2006).

Most wells and springs sampled for the ArbuckleSimpson geochemical reconnaissance were not public water systems, and the water-quality standards do not apply to these wells and springs. However, the USEPA water-quality standards were used to provide a basis for comparison to established water-quality standards. Not every chemical constituent for which the USEPA has established an MCL or SMCL was analyzed as part of the Arbuckle-Simpson geochemical reconnaissance.

In general, the waters from wells and springs in the Arbuckle-Simpson aquifer are chemically suitable for all regulated uses, such as public supplies. Dissolved solids concentrations are low, with a median of 347 and an interquartile range of 331 to $384 \mathrm{mg} / \mathrm{L}$. Two domestic wells (sites 2 and 17) produced water with nitrate concentrations of $14.4 \mathrm{mg} / \mathrm{L}$ (coincidentally both wells produced water with identical nitrate concentrations) that exceeded the nitrate MCL of $10 \mathrm{mg} / \mathrm{L}$. Nitrate is the most widespread contaminant of ground water (Hallberg and Keeney, 1993). Unique conditions not associated with the Arbuckle-Simpson aquifer are required for nitrate to be naturally elevated in ground water; therefore, most elevated nitrate is associated with anthropogenic activity such as agriculture or waste disposal. Potential sources of nitrate associated with the Arbuckle-Simpson aquifer are livestock and domestic septic systems. Many of the sampled wells are shallow domestic or stock wells located near these potential sources of nitrate. Nitrate concentrations are generally well below the MCL in most of the samples, which is a positive outcome from this investigation. No other maximum contaminant levels were exceeded.

Samples from two wells, sites 6 and 15, that represent the confined part of the aquifer, exceeded the SMCL for chloride of $250 \mathrm{mg} / \mathrm{L}$. Samples from site 6 had a chloride concentration of $279 \mathrm{mg} / \mathrm{L}$, and the sample from site 15 had a chloride concentration of $558 \mathrm{mg} / \mathrm{L}$. Both sites are flowing wells from confined parts of the aquifer. One well (site 6) is a stock well that is not used for human consumption, but the other site, Vendome Well (site 15), is a flowing well in Chickasaw National Recreation Area from which visitors frequently drink. Samples from these two wells also exceeded the SMCL of $500 \mathrm{mg} / \mathrm{L}$ for dissolved solids. Samples from site 6 had a dissolved solids concentration of $768 \mathrm{mg} / \mathrm{L}$, and the sample from site 15 had a dissolved solids concentration of $1,250 \mathrm{mg} / \mathrm{L}$. Water samples from these two wells in the confined part of the aquifer are not representative of water samples from the other wells and springs completed in the unconfined part of the aquifer, and both wells consistently are exceptional when considering most aspects of the geochemistry of the Arbuckle-Simpson aquifer. No other water samples from the Arbuckle-Simpson geochemical reconnaissance exceeded SMCLs.

\section{Water Type}

The major ion chemistry of 34 of the 36 water samples was a calcium bicarbonate or calcium magnesium bicarbonate water type. Stiff diagrams, which graphically represent the dominant major cations and anions dissolved in the water, are shown in figure 8 . Each Stiff diagram in figure 8 is located at the site of the well or spring from which the water sample was collected. The geometric pattern of the Stiff diagram and the relative size indicate the general water type and relative concentration of total dissolved solids.

Some wells or springs, such as site 1, produce water in which calcium is the dominant cation (the middle left axis of the Stiff diagram) and bicarbonate (the middle right axis of the Stiff diagram) is the dominant anion. Stiff diagrams of water samples from wells and springs producing water from the Arbuckle Anticline (the western part of the aquifer) show a distinct diamond-shape pattern of calcium bicarbonate type waters. Stiff diagrams of water samples from wells and springs producing water from the Hunton Anticline (the eastern part of the aquifer) have a slightly different shape in which the lower left axis, representing magnesium, is longer (see for example the Stiff diagram for site number 28). Water from the Hunton Anticline tends to have higher magnesium concentration, which is consistent with the geology. The predominant rock type in the Arbuckle Anticline is limestone, which consists mostly of the mineral calcite, $\mathrm{CaCO}_{3}$. The predominant rock type in the Hunton Anticline is dolomite, which consists mostly of the mineral dolomite, $\mathrm{CaMg}\left(\mathrm{CO}_{3}\right)_{2}$ (the term "dolomite" refers to a rock type and a mineral). The water types for sites on the Tishomingo Anticline include both the calcium bicarbonate water type and the calcium magnesium bicarbonate water type.

The two confined-aquifer water samples, as shown by their Stiff diagrams (fig. 8), in which the major ion chemistry is not calcium bicarbonate or calcium magnesium bicarbonate type, are sites 6 and 15. Both water samples have geochemical characteristics distinct from other samples from the Arbuckle-Simpson aquifer. Major ion chemistry in water samples from these two wells is predominantly sodium and chloride. The composition of these samples appears to be a mixture of predominantly typical ArbuckleSimpson calcium magnesium bicarbonate water mixed with a small amount of the brine that resides in the aquifer outside the freshwater zone. These brines, of which the water sample from site 31 (a producing oil well) is typical, are highly concentrated and only a small amount in combination with Arbuckle-Simpson freshwater is required to produce water such as that found in sites 6 and 15. Additional discussion of the chemistry of these two wells is found in the section, "Vendome Well and Site 6." 


\section{Test Well}

Water samples were collected from zones in the test well by using a combination of single and double packers. The sampled zones are shown in the following table:

\begin{tabular}{cc}
\hline & Interval sampled \\
\hline Zone 1 & $<195$ feet \\
Zone 2 & 519-539 feet \\
Zone 3 & $1,209-1,229$ feet \\
Zone 4 & $1,389-1,409$ feet \\
Zone 5 & $>1,490$ feet \\
\hline
\end{tabular}

Results of the chemical analyses of water samples from the five zones in the test well are shown in appendix 1 (site 32, samples 32, 33, 34, 35, and 36). The water chemistry in the zones was remarkably uniform. The dissolved solids concentration ranged from 322 to $332 \mathrm{mg} / \mathrm{L}$, a range of only 3 percent. In general, major ion and trace element chemistry showed very little variation from the highest to lowest interval in the test well. Copper and iron concentrations have a considerably larger range than dissolved solids, but copper and iron could have been introduced from the drilling equipment.

Borehole flowmeter logs (R. Ross, U.S. Environmental Protection Agency, written commun., 2007) obtained after the water samples were collected in the test well show downward flow of water in the borehole under nonpumping conditions. When the test well was sampled, the packers were set and the well was purged at about 7 gallons per minute for a period of over 12 hours, but the sampled water possibly was influenced by downward flow during the 9 months between the drilling of the well and when the well was sampled.

One of the primary purposes for drilling the test well was to determine the thickness of the freshwater zone in the Arbuckle-Simpson aquifer by drilling deep enough to encounter the underlying saline water. Hart (1966) shows saline water underlying freshwater everywhere in southern Oklahoma, although Hart's map shows an insufficient number of data points in the Arbuckle-Simpson aquifer to determine the depth to saline water. Parkhurst and Christenson (1987) show that saline waters in Oklahoma generally are sodium chloride type water, similar to the water from the oil well sampled during this investigation (listed as site 31, sample 31, in appendix 1). None of the chemical analyses for the test well show any indication of elevated concentrations of sodium or chloride. The deepest interval from the test well, zone 5, has the lowest sodium concentration and the second lowest chloride concentration. Thus, the saline water that is expected to underlie the freshwater in the Arbuckle-Simpson aquifer probably is deeper than 1,820 feet at the location of the test well.

\section{Geochemical Reactions}

Several geochemical techniques were used to investigate the chemical reactions that occur between the points of recharge in the aquifer and the points in the flow path where water samples were collected, either wells or springs. Saturation index calculations provide information about dissolution or precipitation of carbonate minerals relative to the water sample. Carbon-13 isotopic data are used to distinguish between processes that occur in the unsaturated zone and those that occur in the saturated zone. Inverse geochemical modeling is used to account quantitatively for the chemical composition of the water sample by mixing of saline and freshwaters and reaction of minerals and gases likely to be present in the aquifer.

\section{Saturation Indices}

Interpretation of the chemical analyses from this study relies on the use of saturation indices and partial pressures of carbon dioxide. The saturation index for a mineral is defined to be the $\log$ of the ion activity product divided by the equilibrium constant for a mineral dissolution reaction (Appelo and Postma, 2005). Given the following reaction for calcite dissolution:

$$
\mathrm{CaCO}_{3}=\mathrm{Ca}^{2+}+\mathrm{CO}_{3}^{2-}
$$

the calcite saturation index is

$$
S I_{\text {Calcite }}=\log 10\left(\frac{a_{\mathrm{Ca}^{2+}} a_{\mathrm{CO}_{3}^{2-}}}{K_{\text {Calcite }}}\right),
$$

where

SI is the saturation index,

$a$ is the activity of an ion, and

$K$ is the equilibrium constant.

The calculation of the log partial pressure of carbon dioxide is similar:

$$
\log 10\left(P_{\mathrm{CO}_{2}}\right)=\log 10\left(\frac{a_{\mathrm{CO}_{2(a q)}}}{K_{\text {Henry }}}\right)
$$

where,

$P_{\mathrm{CO}_{2}}$ is the partial pressure of carbon dioxide, and

$\mathrm{K}_{\text {Henry }}$ is the Henry's law constant for carbon dioxide.

Saturation indices and carbon dioxide partial pressures were calculated with the geochemical model PHREEQC (Parkhurst and Appelo, 1999) by using the ion-association aqueous model. Saturation indices can be interpreted as follows: If the saturation index is greater than zero, the mineral could precipitate, but cannot dissolve; if the saturation index is less 
than zero, the mineral could dissolve, but cannot precipitate; if the saturation index is near zero, the mineral could be reacting sufficiently fast to attain equilibrium between the mineral and the solution. The word "could" is used to indicate that kinetics are involved in the mineral reactions; although reactions may be favored thermodynamically, they may proceed rapidly, slowly, or not at all, depending on the kinetics of the reaction.

\section{Carbonate Reactions}

Water in the aquifer of the three anticlines of the Arbuckle-Simpson aquifer is predominantly calcium bicarbonate or calcium magnesium bicarbonate composition that is formed by uptake of carbon dioxide in the unsaturated zone and reaction with calcite and dolomite in the unsaturated and saturated zones. Partial pressures of carbon dioxide in ground water range from 0.1 to 0.01 atmosphere with a trend toward lower partial pressures with depth (fig. 9C). The partial pressures are greater than atmospheric carbon dioxide $(0.0003$ atmosphere) because of generation of carbon dioxide in the unsaturated zone by plant respiration and decay of organic matter. The downward trend in the partial pressure of carbon dioxide with depth can be explained by loss of contact with unsaturated-zone carbon dioxide gas and consumption of dissolved carbon dioxide by dissolution of carbonate minerals in the saturated zone.

Ground water in the study area is near saturation with calcite ( $\mathrm{SI}_{\text {calcite }}$ greater than -0.2), whereas water is substantially undersaturated with dolomite SI $_{\text {dolomite }}$ less than -0.4 (a larger value is used for dolomite than calcite because of the two carbonate ions in the dolomite formula, $\left.\mathrm{CaMg}\left(\mathrm{CO}_{3}\right)_{2}\right)$ compared to one carbonate ion in the calcite formula, $\mathrm{CaCO}_{3}$ ]. The undersaturation of dolomite is caused either by absence of dolomite in the formations or slow reaction kinetics of dolomite. All samples from the Arbuckle Anticline, one sample from the Tishomingo Anticline, and one sample from the Hunton Anticline have dolomite saturation indices of -1.0 or less, which may indicate limited availability of dolomite. All other samples have dolomite saturation indices of -0.4 or greater, which probably indicate water compositions that are approaching dolomite saturation with time. Helium-tritium dating (see the Ground-Water Dating section of this report) indicates that most samples with dolomite saturations of -0.4 or greater are less than 40 years old. The four samples that are more than 40 years old are near saturation with dolomite.

\section{Carbon-13}

Carbon-13 isotopic data provide insight into the processes affecting carbon that occur in the saturated and unsaturated zones. Carbon-13 is measured as the ratio of the abundance of carbon-13 atoms to carbon-12 atoms relative to the ratio in a standard. The data are presented as permil relative to the standard and are compared here by using the terms lighter (relatively less carbon-13) and heavier (relatively more carbon-13). For example, a sample with a negative permil value is lighter than the standard, which has a permil value of zero. Many processes cause fractionation of carbon-13, which means that one of the isotopes (carbon-12 or carbon-13) is used preferentially in the process. For example, the distribution of carbonate between aqueous solution and calcite results in carbon isotopes in calcite that are heavier than the carbon isotopes in solution.

Carbon dioxide produced by most terrestrial plants (C3 plants) in the unsaturated zone generally has a carbon-13 isotopic signature of about -27 permil (Appelo and Postma, 2005). Differential diffusion between carbon-12 and carbon-13 causes the gas phase to be heavier (enriched in carbon-13) by about 4 permil (Cerling, 1984), resulting in unsaturated zone carbon dioxide isotopic composition of about -23 permil. If carbonate minerals react to equilibrium in the unsaturated zone, the carbon-13 composition of water entering the saturated zone will be in isotopic equilibrium with the unsaturatedzone gas. Equilibrium fractionation between gas and water is $\mathrm{pH}$ and temperature dependent; at $18{ }^{\circ} \mathrm{C}$ and $\mathrm{pH} 7.0$, the fractionation factor is about 7 permil (Mook, Bommerson, and Staverman, 1974) as calculated by NETPATH (Plummer, Prestemon, and Parkhurst, 1994). Thus, the isotopic composition of inorganic carbon in the water will be 7 permil heavier than the gas, or about -16 permil. Alternatively, if no carbonate minerals dissolve in the unsaturated zone, the fractionation factor between gas and water will be about -1 permil and the isotopic composition of the dissolved inorganic carbon in the water entering the saturated zone will be about -24 permil. If carbonate minerals have a typical marine carbonate carbon-13 composition of about 0 permil and all dissolution occurs in the saturated zone, then ground water will have a carbon-13 composition of about -12 permil (Appelo and Postma, 2005).

The isotopic compositions of the six reconnaissance water samples analyzed for carbon-13/carbon-12 ratio are in the range of -7.2 to -12.8 (appendix 1). These values tend to be heavier than would be expected from the arguments of the previous paragraph. One possible explanation for the heavierthan-expected isotopic composition of the ground water is dissolution of dolomite with calcite precipitation. The kinetics of calcite reactions appear to be faster than that of dolomite, as indicated by the saturation indices for calcite generally near zero and dolomite less than zero. After the initial dissolution of calcite to equilibrium, continued slow dissolution of dolomite will cause precipitation of calcite. Carbon from dolomite dissolution will be about 0 , which will cause dissolved carbon to become heavier, and carbon in the precipitated calcite will be about 1 permil heavier than the dissolved carbon-13, which will cause the dissolved carbon to become lighter. Although these two processes compete, the combined effect of dolomite dissolution and calcite precipitation will be to drive the carbon-13 composition to heavier values. Thus, for ground water in the Arbuckle-Simpson aquifer, the most likely sequence of reactions that explains the chemical and carbon-13 composition of the water is that carbon dioxide is taken up in the unsaturated zone and dissolves the host 

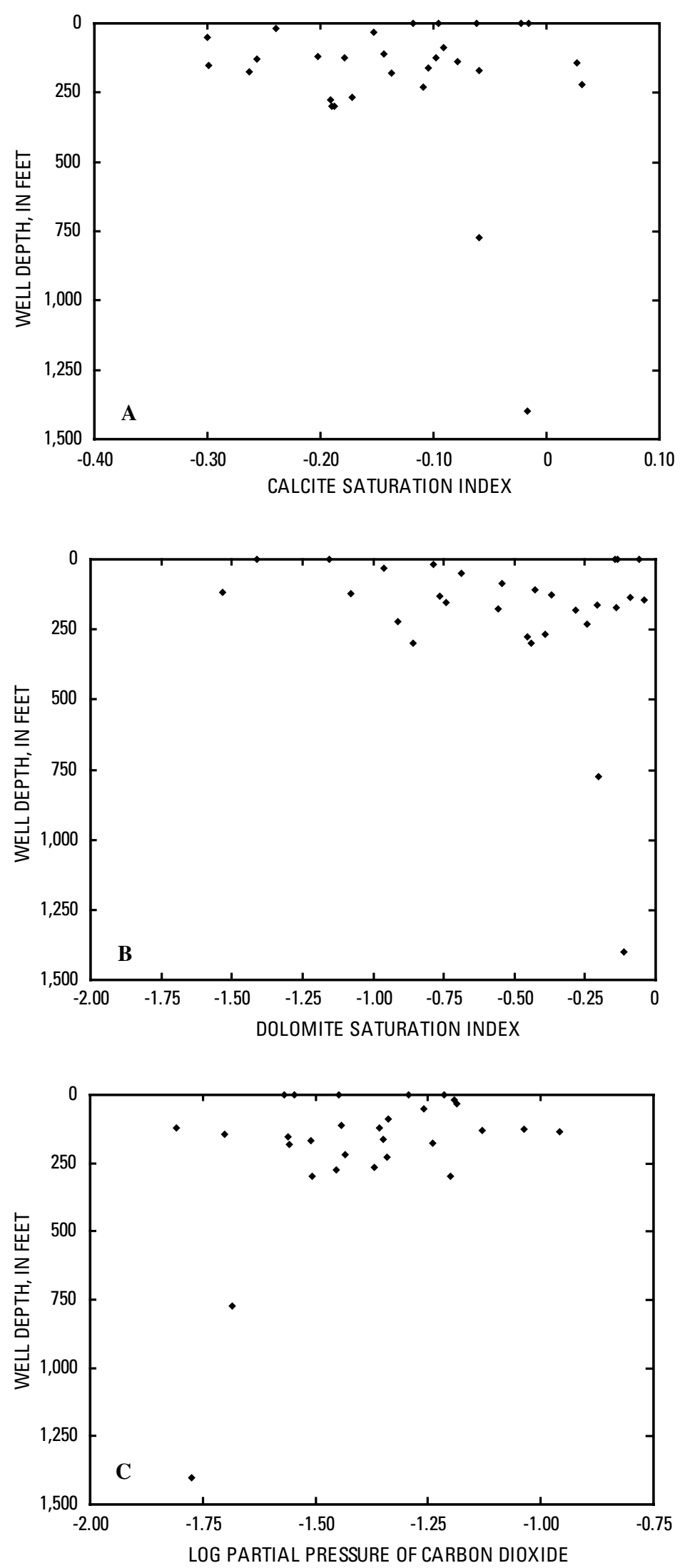

Figure 9. Calcite and dolomite saturation indices and log partial pressure of carbon dioxide. 
rock, either limestone or dolomite. The carbon dioxide reacts quickly to dissolve calcite in the unsaturated zone, whereas dolomite dissolves more slowly. However, dolomite continues to dissolve in the saturated zone, with concurrent precipitation of calcite.

Other factors affect the isotopic composition of the ground water and may explain the heavy isotope compositions: (1) the carbon-13 of the plants is uncertain; for example, -25 permil is often cited (Drever, 1982); (2) isotopic exchange may occur between the carbonate rocks and the water; isotopic exchange equilibrium would indicate that, given geologic time, the carbon- 13 of the water should be 1 or 2 permil lighter than the source rocks (assumed to be 0); (3) there may be an influence of $\mathrm{C} 4$ plants (some arid-zone plants), which have a carbon-13 signature of about -13 permil (Appelo and Postma, 2005); and (4) carbon-13 values heavier than 0 permil are possible in diagenetic dolomites.

\section{Vendome Well and Site 6}

The water compositions at the Vendome Well (site 15) and site 6 represent old waters that are found at the edges of the freshwater aquifer. These two sites were the only sites for which carbon-14 ages were calculated because all other waters from the aquifer had tritium concentrations that indicated a fraction of modern water. Inverse geochemical models were calculated by PHREEQC (Parkhurst and Appelo, 1999) to account for chemical reactions that affect the carbon-14 activities of the water samples from Vendome Well and site 6. Inverse models account for the concentrations of all major ions in the evolution from one water composition to another by dissolution and precipitation of minerals and gases. The inverse modeling accounts for the concentrations of calcium, magnesium, sodium, silica, chloride, sulfate, and carbon. To simplify results, potassium and nitrogen were not included because they were considered to be minor constituents in the analyses. PHREEQC allows assignment of uncertainty to the analyzed concentrations; for these calculations, an uncertainty of 10 percent was applied to all concentrations in all solutions.

The carbon-13 data and the saturation indices indicate that calcite dissolves followed by dolomite dissolution and calcite precipitation. The inverse models for the two water samples were derived by assuming recharge initially equilibrates with calcite. A PHREEQC calculation generated a water composition (starting from pure water) with log partial pressure of carbon dioxide of -1.7 that was in equilibrium with calcite. This partial pressure was selected because no further addition or removal of carbon dioxide was needed in modeling the Vendome Well or site 6 samples. It was assumed in the inverse models that the water compositions evolved from this calcite-saturated solution (representing water recharged to the saturated zone) with an admixture of brine, as represented by the brine analysis ( site 31 ; appendix 1 ). The chloride-tobromide mass ratio of the brine (260) is similar to the ratio in seawater (287). This similarity indicates that the brine is derived from evaporation of seawater, but the evaporation did not proceed past the point of precipitating halite (sodium chloride). The saturation index for halite in the brine is -1.6 , which is consistent with a solution undersaturated with halite.

In addition to mixing of waters, the inverse modeling included the following possible reactants: calcite, dolomite, gypsum, sodium feldspar (albite), quartz, and kaolinite. Carbon dioxide was not included because the inverse modeling attempted to account only for reactions in the saturated zone. Calcite and dolomite can be considered to be present throughout the aquifer surrounding the two sampling sites. Large sulfate concentrations are apparent in the sample analyses and gypsum (or anhydrite) is the most likely reactant. Gypsum is not abundant in the aquifer, although traces have been identified (Donovan, 1991). Gypsum may be present as inclusions within the carbonate minerals of the aquifer, which could weather out slowly as the carbonate minerals dissolve or recrystallize. Weathering of feldspars to quartz (or chalcedony) and kaolinite is a common process, although the rates of weathering may be slow. Feldspars are common minerals that are likely to be present in all of the formations of the Arbuckle-Simpson aquifer.

Inverse modeling determined a relatively simple set of reactions that account for the compositions of the two water samples. Mixing the calcite-saturated recharge water and brine and dissolving calcite, dolomite, and gypsum account for each of the water compositions (table 6). The mole transfers of minerals are similar between the two samples. The primary difference between the two models is that Vendome Well has a larger mixing fraction of brine, about 1 percent, compared to site 6 , about 0.5 percent. The mixing fractions also account for the concentrations of bromide and iodide in the two samples, which are expected to be conservative constituents of the brine. Although site 6 is about 25 miles from the Vendome Well and from the well where the brine was sampled, the same brine composition accounts for the conservative elements in the site 6 sample, which indicates a brine of similar composition is likely to be present below the entire freshwater zone of the Hunton Anticline part of the Arbuckle-Simpson aquifer. The brine component of the sample at Vendome Well is likely to account for the relatively large concentrations of many of the trace elements (potassium, fluoride, bromide, iodide, ammonia, arsenic, boron, lithium, selenium, and strontium).

Table 6. Inverse models for Vendome Well and site 6 .

[Mixing fractions are unitless; mole transfers for calcite, dolomite, and gypsum are millimoles per liter; negative mole transfers indicate precipitation, positive dissolution]

\begin{tabular}{|c|c|c|c|c|c|}
\hline \multirow{2}{*}{ Well } & \multirow{2}{*}{$\begin{array}{l}\text { Mixing } \\
\text { fraction of } \\
\text { recharge } \\
\text { water }\end{array}$} & \multirow{2}{*}{$\begin{array}{l}\text { Mixing } \\
\text { fraction } \\
\text { of brine }\end{array}$} & \multicolumn{3}{|c|}{ Mole transfer } \\
\hline & & & Calcite & Dolomite & Gypsum \\
\hline Vendome Well & 0.991 & 0.009 & -2.36 & 1.24 & 0.24 \\
\hline Site 6 & .995 & .005 & -2.45 & 1.32 & .29 \\
\hline
\end{tabular}


If the recharge water is assumed to have carbon-13 of -12 permil (closed system from Appelo and Postma, 2005), then the calculated carbon-13 for the water samples, accounting for the inverse modeling reactions, are Vendome Well -8.3 and site 6 sample -8.1, compared to measured values of -8.21 and -8.44. To obtain this similarity, most dissolution of carbonate minerals was assumed to occur in the saturated zone and that dissolution of calcite precedes dissolution of dolomite.

No feldspar weathering reactions were needed in the two inverse models, although these reactions are plausible. This lack of reaction probably results from two factors. First, feldspar dissolution is expected to be limited, and is likely to be insignificant relative to the 10 percent uncertainties assigned to the calculation. Similarly, the "minimal" model option was used in the calculation, which actively tries to eliminate reactants, if possible, by making concentration adjustments within the uncertainty limits.

The Vendome Well and the site 6 well sample both have substantial ammonium concentrations, no nitrate, and a smell of hydrogen sulfide. These observations are consistent with a reducing environment; however, the fact that some sulfate remains in solution indicates that the chemical environment is not extremely reducing. The reduced species may be derived from the brine, which is certainly in a reducing environment when in the presence of petroleum. Ammonium concentrations in the two samples are consistent with dilution of the ammonium concentration in the brine (given a 20 percent uncertainty in the analytical data). Alternatively, the water discharging at the wells has encountered organic material at some point along the flow path that has removed oxygen and nitrate, generated ammonium, and produced a slight amount of sulfate reduction.

\section{Ground-Water Dating}

Ground-water dating refers to the process of measuring the amount of time elapsed since a parcel of ground water became isolated from the atmosphere. The actual dating of water in almost all cases relies on the measurement of a specific tracer that is introduced to the ground water at the water table by a known physicochemical or biological process. The parcel of water then becomes isolated from the atmosphere with subsequent recharge and thus begins to "age." This measured time component is considered a mean residence time for the ground water within an aquifer.

Understanding that there can be vast differences in the age of ground water within a given flow system, a simple system for classification is commonly used. "Modern" ground water is considered to have been recharged within the past few decades (after 1950) and are considered part of the active hydrological cycle; "sub-modern" water is considerably older (pre-dating 1940s) and is defined by the lack of measurable tritium $\left({ }^{3} \mathrm{H}\right)$ in the water.

Within the context of the Arbuckle-Simpson Hydrology Study, ground-water dating is used to evaluate the modern ground-water component of the regional flow system. Three separate techniques were used: helium-3/tritium $\left({ }^{3} \mathrm{He} /{ }^{3} \mathrm{H}\right)$, chlorofluorocarbons (CFCs), and carbon-14 $\left({ }^{14} \mathrm{C}\right)$ techniques. Each technique has its strengths and drawbacks within groundwater flow systems, but the techniques can be used in combination to validate assumptions used in ground-water dating.

\section{Helium-3/Tritium Dating}

Tritium $\left({ }^{3} \mathrm{H}\right)$ is the radioactive isotope of hydrogen, which decays by beta decay to helium-3 $\left({ }^{3} \mathrm{He}\right)$ with a half-life of 12.33 years (Lucas and Unterweger, 2000). Unlike CFCs, which rely on solubility conditions to be introduced into ground-water systems, ${ }^{3} \mathrm{H}$ originates as part of the water molecule (for example, ${ }^{3} \mathrm{H}-{ }^{1} \mathrm{H}-\mathrm{O}$ ) and represents an almost perfect, conservative tracer. ${ }^{3} \mathrm{H}$, in the form of water in the atmosphere, is mainly associated with atmospheric testing of nuclear weapons that began in 1952 and reached a maximum in 1963-64. However, there is a natural production source associated with cosmic-ray interaction with nitrogen in the upper atmosphere. The nature of the ${ }^{3} \mathrm{H}$ input (mainly anthropogenic) to the atmosphere produces a spike-like input to an aquifer associated with the nuclear testing maximum and a decay curve as the initial input goes through radioactive decay to natural production levels. ${ }^{3} \mathrm{H}$ dating technique is similar to CFCs in that a measured concentration can be used to determine age through comparison to a historic input curve; however, the real strength comes from a separate measurement of ${ }^{3} \mathrm{He}$ contained in the ground water to produce an apparent age based on radioactive decay of parent isotope to daughter. This technique requires two separate samples, one for the measurement of tritiogenic helium-3 $\left({ }^{3} \mathrm{He}^{*}\right.$, derived from decay of $\left.{ }^{3} \mathrm{H}\right)$ contained as a dissolved gas in the ground water and the other for the low-level measurement of the ${ }^{3} \mathrm{H}$ by ${ }^{3} \mathrm{He}$ in-growth.

Measurement of ${ }^{3} \mathrm{He}^{*}$ involves the analysis of the dissolved gas contained in a ground-water sample. As precipitation in the form of water enters an aquifer, solubility conditions [temperature, partial pressure (altitude and composition of gas), and salinity] present at the water table control the amount of dissolved gas present in the ground water. Air, having very uniform composition with respect to the noble gases, forms a distinctive dissolved gas composition in equilibrium with the ground water. This distinctive composition is termed air-saturated water (ASW). By measuring the helium isotopic composition $\left({ }^{3} \mathrm{He} /{ }^{4} \mathrm{He}\right.$ ratio expressed as $\mathrm{R} / \mathrm{R}_{\mathrm{A}}\left[\left({ }^{3} \mathrm{He} /{ }^{4} \mathrm{He}_{\text {sample }}\right) /\right.$ $\left.\left.\left({ }^{3} \mathrm{He} /{ }^{4} \mathrm{He}_{\text {atmosphere }}\right)\right]\right)$ and concentrations of helium $(\mathrm{He})$, nitrogen $\left(\mathrm{N}_{2}\right)$, neon $(\mathrm{Ne})$, argon (Ar), krypton $(\mathrm{Kr})$, and xenon $(\mathrm{Xe})$, amounts of ${ }^{3} \mathrm{He}$ associated with solubility conditions and excess gas (additional amounts of excess air and/or terrigenic helium) can be resolved (Schlosser and others, 1989). The data derived from the analysis separates out the various sources of ${ }^{3} \mathrm{He}$ contained in the sample and solves for the tritiogenic ${ }^{3} \mathrm{He}$ by:

$$
{ }^{3} \mathrm{He}^{*}={ }^{3} \mathrm{He}_{\text {measured }}-{ }^{3} \mathrm{He}_{\text {solubility }}-{ }^{3} \mathrm{He}_{\text {exair }}-{ }^{3} \mathrm{He}_{\text {terrigenic, }}
$$


where

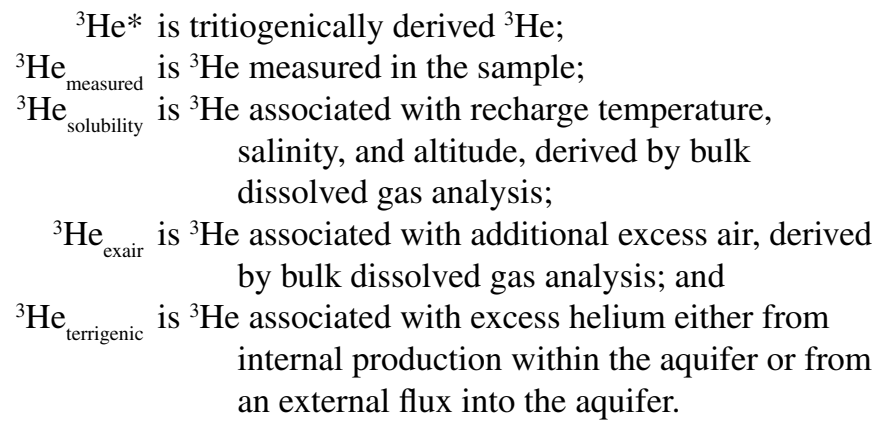

The measurement of ${ }^{3} \mathrm{H}$ was performed by the ${ }^{3} \mathrm{He}$ in-growth method for determinations as low as 0.05 tritium unit (TU) ( $1 \mathrm{TU}$ is $1{ }^{3} \mathrm{H}$ atom per $10^{18}$ hydrogen atoms). The method involves degassing a sample of water and sealing the degassed water off from the atmosphere within a measuring vessel for a period of 2 to 3 months. The sample is then analyzed for the amount of ${ }^{3} \mathrm{He}$ produced by ${ }^{3} \mathrm{H}$ decay over the time period ( ${ }^{3} \mathrm{He}$ in-growth) and the amount of ${ }^{3} \mathrm{H}$ is then calculated (Bayer and others, 1989).

Using the data from both the dissolved gas measurement and the tritium analysis, the apparent age of the sample is calculated from the following equation:

$$
\mathrm{t}=\mathrm{T}_{1 / 2} / \ln (2) * \ln \left(1+\left({ }^{3} \mathrm{He}^{* / 3} \mathrm{H}\right)\right),
$$

where

$\mathrm{t}$ is the apparent age, in unit time;

$\mathrm{T}_{1 / 2}$ is the half-life of ${ }^{3} \mathrm{H}$, in unit time; and

${ }^{3} \mathrm{He}^{* / 3} \mathrm{H}$ is the measured ratio of ${ }^{3} \mathrm{He}^{*}$ and ${ }^{3} \mathrm{H}$.

\section{Chlorofluorocarbons}

CFCs are stable, synthetic organic compounds that were first produced in the 1930s and are purely of anthropogenic origin in the atmosphere. Since the 1930s CFCs have accumulated in the atmosphere at a quantifiable rate, thus yielding a CFC concentration-to-age relation in modern ground water. Concentrations within waters are controlled by the solubility of the gas in water, which in turn is controlled mainly by the partial pressure (altitude and mole fraction) of the constituent CFC (CFC-11, CFC-12, and CFC-113) in the atmosphere and recharge temperature of the ground water. Simply by measuring the dissolved concentration of a CFC in a water sample, an atmospheric concentration can be computed and then compared to a known time series of atmospheric concentration to estimate an age for the sample (Plummer, Busenberg, and Cook, 2006). Analysis of CFCs is preformed on a gas chromatograph fitted with an electron capture detector, which allows for the measurement of CFC-11, CFC-12 and CFC-113 to concentrations as low as 0.3 picograms per kilogram (pg/ $\mathrm{kg}$ ). This analysis typically produces three complementary ages, each associated with a common CFC. For a full explanation see Plummer and Busenberg (1999), Plummer (2005), and Plummer, Busenberg, and Cook (2006).

\section{Carbon-14 Dating}

Carbon-14 is a naturally occurring radioactive isotope that forms in the atmosphere and decays with a half-life of 5,730 years. To use carbon-14 to estimate ground-water ages involves three steps: (1) an estimate of the carbon-14 activity at the time ground water entered the saturated zone, (2) an inverse model defining the quantitative extent of each carbon-affecting reaction in the saturated zone, and (3) the age calculation. The initial carbon-14 activity $\left(A_{0}\right)$ applies to the calcite-saturated recharge water that was used in the inverse modeling for the Vendome Well and site 6 samples. For calculations in this report, $A_{0}$ was specified by the Fontes and Garnier (1979) model, using an open-system for soil carbon-13 gas of NETPATH (Plummer, Prestemon, and Parkhurst, 1994. The adjusted carbon-14 activity accounting for reactions (and, for no decay) is derived from the inverse modeling of the "Vendome Well and Site 6" section of this report. The age calculation is

$$
t=\frac{5730}{\ln (2)} \ln \left(\frac{A_{n d}}{A}\right)
$$

where

$t$ is the age of the sample in years;

$A_{n d}$ (no decay) corrects the initial estimate of ${ }^{14} \mathrm{C}$ activity $\left(A_{o}\right)$ with reactions of the NETPATH inverse models, but not for the decay of ${ }^{14} \mathrm{C}$; and

$A$ is the measured activity of ${ }^{14} \mathrm{C}$.

\section{Dating Results}

The results of the isotopic and compositional analyses for dissolved gas constituents are presented in table 7. Because ground water in the Arbuckle-Simpson aquifer consists of freshwater infiltrating across a relatively flat area (known salinity and partial pressures), the main variable controlling solubility of dissolved atmospheric gas is the recharge temperature. Typical recharge temperatures should be close to those measured in the shallow aquifer and be related to mean annual temperatures for the region (Stute and Sonntag, 1992). A comparison of the measured data to known dissolved gas concentrations at $16{ }^{\circ} \mathrm{C}$ (mean annual temperature from Ada, Oklahoma), shows that most samples contain more dissolved gas constituents than can be explained by simple solubility conditions alone (table 7). The amount of excess dissolved gas above that of solubility concentrations could be attributed to colder recharge temperatures and/or the addition of excess gas to solution. One source of excess dissolved gas is the introduction of excess air during recharge (Heaton and Vogel, 1981). Recharging water to a fractured or karstic bedrock aquifer typically entraps extra amounts of atmospherically derived gas (air) during recharge. This excess air is forced into solution with increasing hydrostatic pressure during recharge, giving 
Table 7. Dissolved gas data.

[Dissolved gas data are given in units of gas volume at standard pressure and temperature per unit mass of water; cc, cubic centimeter; kg, kilogram; STP, standard temperature and pressure; $\mu \mathrm{cc}$, micro-cubic centimeter; $\mathrm{R} / \mathrm{R}_{\mathrm{A}}$, ratio of (ratio of helium-3/helium-4 in sample) to (ratio of helium-3/helium- 4 in atmosphere); <, less than; NA, not analyzed; ASW, air saturated water; ${ }^{\circ} \mathrm{C}$, degree Celsius]

\begin{tabular}{|c|c|c|c|c|c|c|c|c|c|c|c|}
\hline $\begin{array}{c}\text { Site/sample } \\
\text { number }\end{array}$ & $\begin{array}{c}\text { Nitrogen } \\
\left(\mathrm{N}_{2}\right) \\
(\mathrm{cc} / \mathrm{kg} \\
\text { STP) }\end{array}$ & $\begin{array}{c}\text { Methane } \\
\left(\mathrm{CH}_{4}\right) \\
\text { (cc/kg } \\
\text { STP) }\end{array}$ & 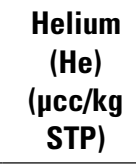 & $\begin{array}{c}\text { Neon } \\
\text { (Ne) } \\
\text { (pcc/kg } \\
\text { STP) }\end{array}$ & $\begin{array}{c}\text { Argon } \\
\text { (Ar) } \\
\text { (cc/kg } \\
\text { STP) }\end{array}$ & $\begin{array}{c}\text { Krypton } \\
\text { (Kr) } \\
\text { (pcc/kg } \\
\text { STP) }\end{array}$ & 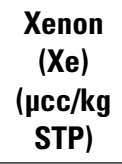 & $\begin{array}{l}\mathbf{R} / \\
\mathbf{R}_{\mathrm{A}}\end{array}$ & $\begin{array}{l}{ }^{20} \text { Neon/ } \\
{ }^{22} \text { Neon }\end{array}$ & $\begin{array}{l}{ }^{40} \text { Argon/ } \\
{ }^{36} \text { Argon }\end{array}$ & $\begin{array}{c}\text { Nitrogen } \\
\left(\mathbf{N}_{2}\right) / \\
\text { Argon }\end{array}$ \\
\hline $1 / 1$ & 15.10 & $<0.02$ & 62.1 & 230.0 & 0.355 & 78.8 & 10.3 & 0.939 & 9.85 & 295.8 & 42.55 \\
\hline $2 / 2$ & 31.11 & $<.02$ & 148.1 & 473.4 & .501 & 99.3 & 12.7 & 1.014 & 9.80 & 289.8 & 62.10 \\
\hline $3 / 3$ & 19.08 & $<.02$ & 81.2 & 277.6 & .434 & 94.6 & 12.7 & 1.324 & 9.84 & 295.6 & 43.95 \\
\hline $5 / 5$ & \multicolumn{11}{|c|}{ No sample } \\
\hline $6 / 6$ & 22.33 & $<.02$ & $8,022.6$ & 282.7 & .459 & 102.5 & 14.6 & .062 & 9.82 & 295.2 & 48.64 \\
\hline $7 / 7$ & 23.09 & $<.02$ & 107.9 & 399.4 & .460 & 99.9 & 13.2 & 1.018 & 9.93 & 295.6 & 50.18 \\
\hline $8 / 8$ & 16.07 & $<.02$ & 67.6 & 276.2 & .385 & 78.1 & 11.4 & 1.128 & 9.85 & 293.4 & 41.80 \\
\hline $12 / 12$ & 16.46 & $<.02$ & 50.3 & 203.0 & .319 & 76.3 & 10.8 & .972 & 9.86 & 294.0 & 51.63 \\
\hline $13 / 13$ & 14.67 & $<.02$ & 57.8 & 234.9 & .366 & 81.3 & 11.0 & 1.251 & 9.81 & 295.7 & 40.06 \\
\hline $14 / 14$ & 24.64 & $<.02$ & 139.8 & 325.5 & .449 & 93.0 & 12.3 & .865 & 9.80 & 293.6 & 54.89 \\
\hline $15 / 15$ & 29.02 & $<.02$ & 21,479 & 399.3 & .518 & 111.3 & 12.2 & .059 & 9.80 & 297.0 & 56.02 \\
\hline $16 / 16$ & 16.72 & $<.02$ & 64.5 & 267.7 & .385 & 85.6 & 11.4 & 1.162 & 9.85 & 291.7 & 43.43 \\
\hline $17 / 17$ & \multicolumn{11}{|c|}{ No sample } \\
\hline $18 / 18$ & 15.84 & $<.02$ & 47.7 & 197.4 & .324 & 76.9 & 10.7 & 1.018 & 9.85 & 295.6 & 48.89 \\
\hline $19 / 19$ & 11.27 & $<.02$ & 44.8 & 194.4 & .312 & 73.9 & 10.0 & .970 & 9.86 & 294.9 & 36.09 \\
\hline $25 / 25$ & 16.21 & $<.02$ & 46.0 & 190.0 & .322 & 79.3 & 11.0 & .986 & 9.88 & 293.3 & 50.38 \\
\hline $26 / 26$ & 17.80 & $<.02$ & 65.2 & 271.6 & .380 & 85.6 & 11.6 & 1.001 & 9.84 & 296.0 & 46.87 \\
\hline $27 / 27$ & \multicolumn{11}{|c|}{ No sample } \\
\hline $28 / 28$ & 16.36 & $<.02$ & 61.8 & 239.8 & .383 & 88.0 & $\mathrm{NA}$ & 1.203 & 9.87 & 296.5 & 42.68 \\
\hline $29 / 29$ & \multicolumn{11}{|c|}{ No sample } \\
\hline $30 / 30$ & 21.92 & $<.02$ & 157.3 & 422.6 & .484 & 94.2 & 12.2 & .752 & 9.77 & 295.4 & 45.33 \\
\hline $31 / 31$ & \multicolumn{11}{|c|}{ No sample } \\
\hline $32 / 32$ & 20.84 & $<.02$ & 83.0 & 344.3 & .472 & 98.8 & 13.0 & 1.054 & 9.79 & 295.6 & 44.18 \\
\hline $32 / 33$ & 19.69 & $<.02$ & 88.7 & 334.2 & .445 & 93.8 & 12.5 & 1.307 & 9.80 & 296.6 & 44.24 \\
\hline $32 / 34$ & \multicolumn{11}{|c|}{ Too much dissolved gas, data unresolvable } \\
\hline $32 / 35$ & 44.72 & $<.02$ & 207.1 & 828.5 & .764 & 120.8 & 14.2 & 1.089 & 9.79 & NA & 58.51 \\
\hline $32 / 36$ & 19.69 & $<.02$ & 81.8 & 321.7 & .418 & 88.3 & 11.8 & 1.267 & 9.84 & 293.9 & 47.10 \\
\hline ASW $16^{\circ} \mathrm{C}$ & 12.37 & $<.02$ & 43.7 & 184.2 & .326 & 74.3 & 10.4 & .980 & 9.80 & 295.5 & 37.94 \\
\hline
\end{tabular}


a characteristic composition that resembles a mix between the solubility and an air-like composition. Aeschbach-Hertig and others (1999) further add to this explanation of excess gas within samples by demonstrating that the initial excess air component may experience partial loss of the excess gas, producing a fractionated excess air component.

Shown in figure 10 are the measured dissolved $\mathrm{Ne}$ to $\mathrm{Xe}$ ratios plotted against Ar for the dissolved gas samples; also shown are the modeled data for solubility values (freshwater, 1,000-foot altitude), excess air, and fractionated excess air addition. The plot demonstrates the variations in dissolved gas compositions due in large part to the different solubil- ity of each gas in water $(\mathrm{Xe}>\mathrm{Ar}>\mathrm{Ne}$ ) and the effect of gain and/or loss of excess air. Initial review of the data indicate that there appear to be three rough groupings of recharge conditions. One grouping has relatively warm $\left(\sim 15\right.$ to $\left.20^{\circ} \mathrm{C}\right)$ waters that contain little excess air, another grouping has near mean annual temperature $\left(16^{\circ} \mathrm{C}\right)$ and follows an excess air trend, and a third grouping could be associated with cooler than mean annual temperatures and some amount of excess air. A majority of the sample data reflect waters that contain some form of excess gas introduced during recharge either as excess air (Heaton and Vogel, 1981) or fractionated excess air (Aeschbach-Hertig and others, 1999). Several of the sample

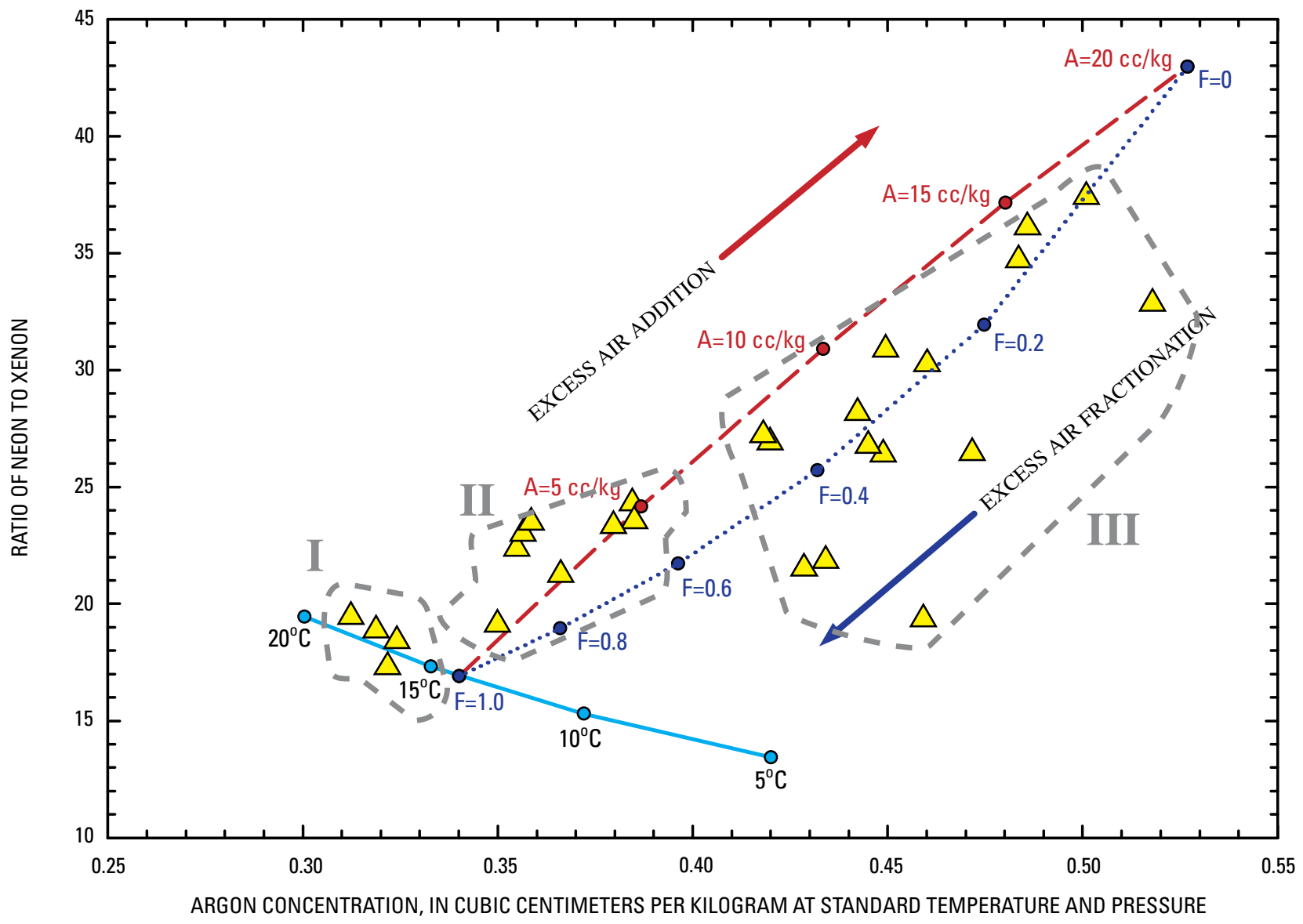

EXPLANATION

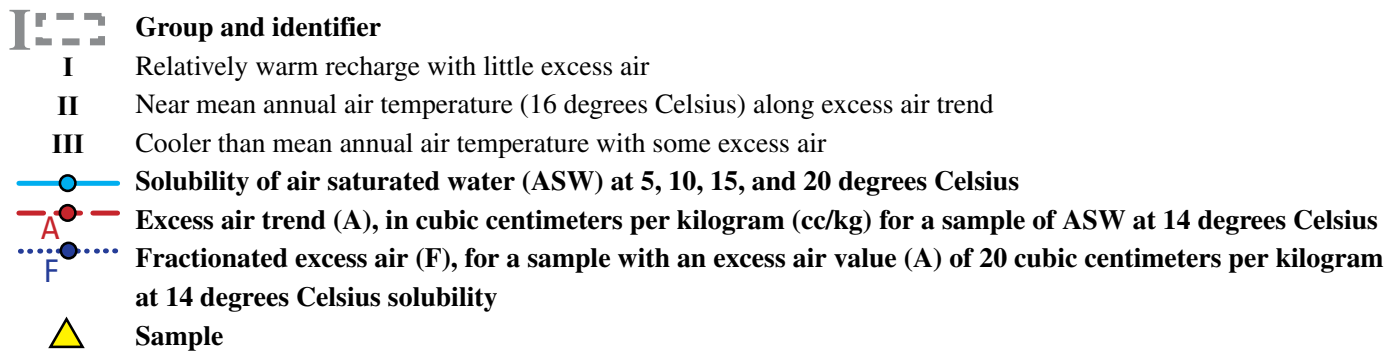

Figure 10. Relation between neon-to-xenon ratio and argon concentration. Model calculations for solubility of air saturated water (ASW) at 5, 10, 15, and 20 degrees Celsius (1,000-foot altitude) are displayed on graph. 
sites $(5,17,23,27,29$, and 31$)$ are not plotted on this figure due to lack of a dissolved gas sample associated with the site, although samples 34 and 35 contained too much excess gas to be plotted on the figure (table 7). Although a dissolved gas analysis was obtained for sample 35 , the data plot outside projected norms for the aquifer, indicating that there is contamination in terms of the dissolved gas composition that may have been introduced during installation of the well.

\section{Dissolved Gas Modeling}

To resolve tritiogenically derived ${ }^{3} \mathrm{He}$, atmospherically derived CFCs, and any terrigenic helium present, the physiochemical conditions associated with recharge must be defined. Recharge parameters for this investigation were derived by using the bulk dissolved gas analysis for each sample $\left(\mathrm{N}_{2}, \mathrm{Ne}, \mathrm{Ar}, \mathrm{Kr}\right.$, and $\left.\mathrm{Xe}\right)$ and application of the closed equilibrium (CE) model after Aeschbach-Hertig and others (1999). The CE model incrementally simulates various dissolved concentrations on the basis of the parameters of atmospheric pressure (altitude), salinity, recharge temperature, excess air, and gas fractionation. A chi-squared test (Helsel and Hirsh, 2002) is used to evaluate each incremental step calculation of the model and compare modeled to measured concentrations of the dissolved gas components [for more complete explanation see Kipfer and others (2002)]. This procedure ultimately optimizes the estimates of the physical parameters associated with recharge from the sample dataset and provides a chi-squared distribution value that is used to evaluate how well the modeled parameters fit the dataset. For execution of the dissolved gas modeling, recharge parameters of altitude (atmospheric pressure) and salinity were assumed to be 305 meters above sea level (1,000 feet above the North American Vertical Datum of 1988) and 0 percent salinity (freshwater), which constrains the CE model parameters and allows proper application of the chi-squares test. For a complete review of the model and its application see Aeschbach-Hertig and others (1999) or Kipfer and others (2002).

Results of the dissolved gas modeling are presented in table 8 . The data agree well with the graphical results in figure 10 , with typical chi-square distribution value of less than the critical value of 4.0 [as recommended by Kipfer and others (2002)], meaning there is no statistically significant difference between the data and the dissolved gas model and thus the model can be considered to fit the data. Sample numbers 12 , 20 , and 25 have chi-squared distribution values that are greater than the critical value of $4.0(6.9,4.2$, and 5.0, respectively) but are close enough to the critical value to conclude the model may fit the data. Sample 35 did not meet the requirement to pass the chi-square test (the chi-square distribution value was 12.1 ), meaning that a statistically significant difference exists between the data and the dissolved gas model, and to conclude the model does not fit the data. As noted previously the amounts of dissolved gas contained in sample 35 are far higher than would be associated with natural recharge conditions, and the sample may be contaminated with respect to dissolve gas concentration.

Resolved recharge temperatures vary greatly within the study area. As predicted in figure 10, several samples contain recharge temperatures that are well outside the range of temperatures predicted for modern recharge for the area. The mean annual air temperature at Ada, Oklahoma, is $16{ }^{\circ} \mathrm{C}$ and the median temperature of the 30 reconnaissance water samples was $18.1^{\circ} \mathrm{C}$. Recharge temperatures for samples 6 and 15 are clearly too cold $\left(8.2\right.$ and $6.6^{\circ} \mathrm{C}$, respectively) to be associated with present day temperatures, and recharge temperatures for samples 7 and $10\left(10.7\right.$ and $9.9{ }^{\circ} \mathrm{C}$, respectively) fall between present day recharge temperatures and those of samples 6 and 15. Samples 6 and 15 are from the two flowing wells producing water from confined parts of the aquifer. The colder recharge temperatures are consistent with recharge from an earlier, cooler time period. The 6- to 8-degree difference is greater than the acceptable value of a 5-degree difference for the area (Stute and others, 1992). This may be a result of a dissolved gas composition that has undergone a minor amount of mass fractionation, which violates the application of the CE model. Thus, the CE-modeled recharge temperature could be abnormally low and not acceptable as a paleo-climate reconstruction (Stute and others, 1992). An explanation for the cooler recharge temperatures for water from samples 7 and 10 is less clear. Both wells are completed in the Simpson Group near the edge of the aquifer, in a hydrogeologic environment compatible with the possibility that the produced water is a mixture of modern and sub-modern water. Of the remaining samples, the average recharge temperature is $14.3+/-2.2^{\circ} \mathrm{C}$. The average temperature is below the mean annual air temperature $\left(16^{\circ} \mathrm{C}\right)$ and the measured ground-water temperatures $\left(18.1^{\circ} \mathrm{C}\right)$ from the investigation. The 2-degree difference could indicate recharge to the aquifer occurs in the cooler seasons, the noble gas modeling (error propagation of CE model) is biased for colder temperatures, or possible sample collection error. Calculating a weighted annual recharge temperature based on mean monthly recharge rates [from hydrograph separation techniques of stream gage data at Blue River at Connerville (Vieux and Calderon, 2005)] and mean monthly air temperature at Ada, Oklahoma (table 2), produces a value of $14.2^{\circ} \mathrm{C}$. This temperature corroborates the calculated noble gas recharge temperatures and indicates that ground-water recharge occurs during the cooler months of the year.

Resolution of terrigenic helium also is defined by the CE model. The excess component is determined by subtracting the modeled helium concentration from the measured. This component is typically referred to as terrigenic helium and represents a non-atmospheric component of helium that is derived from either internal production in the aquifer (for example, Marine, 1979; Solomon, Hunt, and Poreda, 1996; Hunt, 2000; Dowling and others, 2004) or an extrinsic component that entered the aquifer from an external source (for example, Torgersen and Clarke, 1985; and Castro, Stute, and Schlosser, 2000). A majority of the investigations into terrigenic helium focus on its use as a possible age indicator 
Table 8. Dissolved gas modeling and helium-3/tritium $\left({ }^{3} \mathrm{He} /{ }^{3} \mathrm{H}\right)$ age determination.

$\left[{ }^{\circ} \mathrm{C}\right.$, degree Celsius; $\mathrm{A}_{\mathrm{e}}$, initial amount of excess air per unit mass of water; cc, cubic centimeter; kg, kilogram; $\mathrm{F}$, fractionation parameter for the $\mathrm{CE}$ model; ${ }^{3} \mathrm{He}^{*}$, tritiogenically derived helium-3; TU, tritium units; ${ }^{3} \mathrm{H}$, tritium; $\mu \mathrm{cc}$, micro-cubic centimeter; STP, standard temperature and pressure; NA, not applicable; none*, too much excess helium in sample to resolve ${ }^{3} \mathrm{He}^{*} ;<$, less than; $>$, greater than]

\begin{tabular}{|c|c|c|c|c|c|c|c|c|c|c|}
\hline $\begin{array}{c}\text { Site/ } \\
\text { sample } \\
\text { number }\end{array}$ & $\begin{array}{c}\text { Recharge } \\
\text { temperature } \\
\left({ }^{\circ} \mathrm{C}\right)\end{array}$ & $\begin{array}{c}A_{e} \\
(c c / k g)\end{array}$ & $\mathbf{F}$ & $\begin{array}{c}\text { Chi' }^{2} \\
\text { distribution } \\
\text { value }\end{array}$ & $\begin{array}{l}{ }^{3} \mathrm{He}^{*} \\
\text { (TU) }\end{array}$ & $\begin{array}{c}{ }^{3} \mathbf{H} \\
\text { (TU) }\end{array}$ & $\begin{array}{c}\text { Apparent } \\
\text { age } \\
\text { (years) }\end{array}$ & $\begin{array}{c}\text { Recharge } \\
\text { year }\end{array}$ & $\begin{array}{c}\text { Error } \\
(+/- \\
\text { years })\end{array}$ & $\begin{array}{c}\text { Terrigenic } \\
\text { He } \\
\text { ( } \mu \mathrm{cc} / \mathrm{kg} \\
\text { STP) }\end{array}$ \\
\hline $1 / 1$ & 17.0 & 19.44 & 0.686 & 2.2 & 1.79 & 3.12 & 8.1 & 1996.8 & 0.5 & 6.2 \\
\hline $2 / 2$ & 13.6 & 18.99 & .069 & .2 & 14.69 & 3.36 & 29.9 & 1974.9 & .5 & 23.8 \\
\hline $3 / 3$ & 12.1 & 29.51 & .576 & .8 & 23.35 & 3.55 & 36.0 & 1968.8 & .5 & 15.0 \\
\hline $4 / 4$ & 14.4 & 18.44 & .384 & 3.0 & 15.13 & 1.43 & 43.6 & 1961.3 & 1.3 & 26.5 \\
\hline $5 / 5$ & NA & & & & NA & 3.13 & NA & & & \\
\hline $6 / 6$ & 8.2 & 28.73 & .597 & .8 & none* & $<.05$ & $>60$ & & & $7,957.2$ \\
\hline $7 / 7$ & 10.7 & 11.22 & 0 & 1.6 & 3.97 & 2.68 & 16.2 & 1988.7 & .6 & 4.5 \\
\hline $8 / 8$ & 14.9 & 8.45 & .298 & .9 & 5.22 & 2.69 & 19.2 & 1985.6 & .6 & \\
\hline 9/9 & 12.7 & 12.31 & .173 & 1.3 & 11.03 & 2.77 & 28.6 & 1976.3 & .61 & 52.82 \\
\hline $10 / 10$ & 9.9 & 13.36 & .461 & 2.5 & 1.33 & .34 & 28.3 & 1976.6 & 5.1 & \\
\hline $11 / 11$ & 13.9 & 4.11 & .618 & 1.4 & 7.64 & 2.89 & 23.0 & 1981.8 & .6 & 14.3 \\
\hline $12 / 12$ & 16.3 & 1.22 & 0 & 6.9 & 0 & 2.90 & $<.5$ & 2004.8 & .7 & \\
\hline $13 / 13$ & 14.2 & 2.88 & .064 & 1.0 & 8.49 & 2.74 & 25.1 & 1979.7 & .6 & \\
\hline $14 / 14$ & 13.9 & 23.70 & .391 & 0 & 22.71 & 1.63 & 48.1 & 1956.7 & 1.2 & 59.8 \\
\hline $15 / 15$ & 6.6 & 14.60 & .128 & 0 & none* & $<.05$ & $>60$ & & & $21,378.6$ \\
\hline $16 / 16$ & 14.3 & 13.01 & .474 & 1.3 & 6.25 & 1.72 & 27.3 & 1977.6 & 1.0 & \\
\hline $17 / 17$ & NA & & & & NA & 2.67 & NA & & & \\
\hline $18 / 18$ & 15.6 & .73 & 0 & 2.1 & .93 & 2.68 & 5.3 & 1999.5 & .6 & \\
\hline $19 / 19$ & 17.2 & .63 & 0 & 2.1 & $<.1$ & 3.12 & NA & & & \\
\hline $20 / 20$ & 16.8 & 13.35 & .622 & 4.2 & .11 & 3.39 & $<.5$ & 2004.8 & .6 & 8.7 \\
\hline $21 / 21$ & 16.7 & 14.31 & .578 & 1.6 & $<.1$ & 3.51 & $<.5$ & 2004.8 & & \\
\hline $22 / 22$ & 13.7 & 15.16 & .028 & 1.4 & 2.56 & 1.07 & 21.7 & 1983.1 & 1.5 & \\
\hline $23 / 23$ & NA & & & & NA & 4.08 & NA & & & \\
\hline $24 / 24$ & 13.5 & 12.81 & .089 & .0 & 13.40 & 2.60 & 32.3 & 1972.5 & .7 & 48.6 \\
\hline $25 / 25$ & 14.6 & .37 & 0 & 5.0 & .17 & 3.44 & .8 & 2004.0 & .6 & \\
\hline $26 / 26$ & 13.8 & 9.42 & .381 & 1.6 & .39 & 2.69 & 2.4 & 2002.4 & .7 & \\
\hline $27 / 27$ & NA & & & & NA & 2.92 & NA & & & \\
\hline $28 / 28$ & 11.8 & 3.21 & 0 & 3.3 & 7.71 & 3.48 & 20.8 & 1984.1 & .4 & \\
\hline $29 / 29$ & NA & & & & NA & 3.08 & NA & & & \\
\hline $30 / 30$ & 15.3 & 21.40 & .170 & .3 & 5.45 & 1.17 & 30.8 & 1975.1 & 1.5 & 48.8 \\
\hline $31 / 31$ & NA & & & & NA & $\mathrm{NA}$ & NA & & & \\
\hline $32 / 32$ & 12.0 & 22.64 & .354 & 1.2 & 2.69 & 2.69 & 12.3 & 1994.2 & .5 & \\
\hline $32 / 33$ & 12.4 & 13.58 & .243 & 1.2 & 18.76 & 3.03 & 35.1 & 1971.4 & .6 & 5.7 \\
\hline $32 / 34$ & NA & & & & NA & 3.01 & NA & & & \\
\hline $32 / 35$ & 19.5 & 62.97 & .105 & 12.1 & 11.23 & 2.97 & 27.8 & 1978.7 & .6 & \\
\hline $32 / 36$ & 14.5 & 13.95 & .263 & 1.6 & 12.88 & 3.02 & 29.6 & 1976.9 & .6 & \\
\hline
\end{tabular}


in sub-modern ground waters (for example, Torgersen and Clarke, 1985; and Castro, Stute, and Schlosser, 2000) or as a tracer to define mantle or crustal flux into geothermal and natural gas reservoirs. For this investigation, the amount of ${ }^{3} \mathrm{He}$ associated with the isotopic composition of the terrigenic helium component must be defined in order to resolve the total amount of tritiogenic ${ }^{3} \mathrm{He}$ (see equation 5) in a sample. Typical isotopic compositions of terrigenic helium can vary from a radiogenic production ratio $\left(0.02 \mathrm{R} / \mathrm{R}_{\mathrm{A}}\right.$, Andrews, 1985) to a mixture of mantle-derived helium and radiogenically derived helium $\left(\sim 0.2\right.$ to $\left.8 \mathrm{R} / \mathrm{R}_{\mathrm{A}}\right)$. No mantle component was assumed to be associated with the terrigenic helium for these calculations and the amount of ${ }^{3} \mathrm{He}$ correction is calculated by using an isotopic composition of $0.02 \mathrm{R} / \mathrm{R}_{\mathrm{A}}$. About half of the samples measured contain no terrigenic helium, although the other samples contained 6 to 50 percent terrigenic helium, with two samples (6 and 15) dominated ( $>99$ percent) by terrigenic helium. For the samples that contained moderate amounts of terrigenic helium, the amount of terrigenic ${ }^{3} \mathrm{He}$ only represented about 0.5 percent of the total ${ }^{3} \mathrm{He}$ measured; however, samples 6 and 15 contained so much terrigenic helium that the tritiogenic ${ }^{3} \mathrm{He}$ component could not be accurately resolved. The error associated in the estimated terrigenic helium isotopic composition causes either too much or too little ${ }^{3} \mathrm{He}$ to be subtracted from the measured data, giving unreasonably high or negative values of tritiogenic ${ }^{3} \mathrm{He}$.

Overall the application of the CE model to the measured dissolved gas data produced reasonable estimates for recharge parameters, terrigenic helium concentrations, and amounts of tritiogenic ${ }^{3} \mathrm{He}$. The data in table 8 show that a majority of samples contain some tritiogenic ${ }^{3} \mathrm{He}$, which in turn implies that the waters must be associated with modern-age waters. Samples 6 and 15 show sufficient amounts of terrigenic helium at relatively low recharge temperatures to confirm the waters are older than modern waters but not necessarily associated with natural gas (lack of methane; table 7). These two samples represent extremely old ground waters (on the scale of thousands of years of residence time).

\section{Calculated Apparent Age (Mean Residence Time)}

When dealing with ground-water age determination, the absolute age of a sample of ground water is often difficult to obtain. Different techniques frequently produce different ages, often because of the different assumptions that are associated with specific techniques. For this reason the age from a specific technique is referred to as an apparent age. Apparent ages from one technique should be similar to apparent ages from other techniques as long as assumptions for both techniques are valid; however, often this is not the case. Typically, physical factors like the mixing of ground waters of differing ages or in-situ degassing can cause ages to be drastically different between one technique and another. This difference in apparent age distribution often can be used to determine the physical factors (for example mixing or dilution of the tracer) through the use of either concentration-based modeling or comparison to known inputs of a tracer to other tracers (for example, Zuber, 1986; Böhlke, 2006).

\section{Tritium and Helium-3/Tritium Apparent Ages}

${ }^{3} \mathrm{H}$ and ${ }^{3} \mathrm{He}^{*}$ data from the samples are listed in table 8; ${ }^{3} \mathrm{H}$ concentrations are given in $\mathrm{TU}$ and ${ }^{3} \mathrm{He}^{*}$ values also have been converted to TU for ease in the calculation of age. Samples 6 and 15 had ${ }^{3} \mathrm{H}$ values below detection limit (0.05 TU), which confirm the initial observations from the dissolved gas analysis that the samples are sub-modern in age.

Tritium concentrations in the modern waters range between 0.34 and $4.08 \mathrm{TU}$. This narrow range of ${ }^{3} \mathrm{H}$ concentration limits the use of ${ }^{3} \mathrm{H}$ as a quantitative age indicator. Presented in figure 11 is the ${ }^{3} \mathrm{H}$ input curve derived from R.L. Michel (U.S. Geological Survey, written commun., 2008) along with a curve that represents the present day values calculated from the original ${ }^{3} \mathrm{H}$ concentrations. The narrow range of ${ }^{3} \mathrm{H}$ from the samples places a majority of the samples with qualitative recharge dates of $1980(\sim 24$ years $)$ to the present assuming piston-flow conditions in the aquifer. The low tritium concentrations ( 0.34 TU in sample 10$)$ could be related to pre-1960 water. The narrow ${ }^{3} \mathrm{H}$ range in the samples, coupled with low ${ }^{3} \mathrm{H}$ level in the present waters, cannot be used with accuracy to assess ground-water age. Calculating the apparent ${ }^{3} \mathrm{He} /{ }^{3} \mathrm{H}$ age from the data shows a broad range of ages from 48.1 to less than 0.5 years, quantifying an accurate apparent age for the samples. Ten apparent ages are less than 20 years and 16 are greater than 20 years (excluding samples 6 and 15). The fact that most sampled ground water was modern (apparent age less than 55 years) indicates water is moving quickly from recharge areas to discharge at streams and springs.

Plotting the ${ }^{3} \mathrm{He}^{*}$ plus the measured ${ }^{3} \mathrm{H}$ in relation to the apparent age should reconstruct the original ${ }^{3} \mathrm{H}$ input curve for the area. Figure 12 shows the ${ }^{3} \mathrm{H}$ input curve (R.L. Michel, U.S. Geological Survey, written commun., 2008) and the measured ${ }^{3} \mathrm{He} *$ plus ${ }^{3} \mathrm{H}$ plotted against the apparent ${ }^{3} \mathrm{He} /{ }^{3} \mathrm{H}$ age from the dataset. Most of the data points fall on or within error of the dataset; however, several points fall well below the input curve. This disagreement, in part, is related to a mixing between waters that are devoid of tritium and tritiogenic ${ }^{3} \mathrm{He}$ (sub-modern). Samples from sites 4, 10, 14, 16, and 22 fall below the expected ${ }^{3} \mathrm{H}$ input curve and represent a mixture between modern and sub-modern waters. Sites 4 and 14 are from springs, and site 16 is a well located adjacent to a spring. Springs often are the confluence of many flow lines, and the geochemical evidence indicates that water samples from these sites are mixtures of waters of different origin. Site 10 is a well located at the boundary of the aquifer outcrop, and site 22 is a well located at the contact between the Arbuckle and Simpson Groups; both wells are located in hydrogeologic settings where flow lines may converge and thus are consistent with the water samples that are mixtures. 


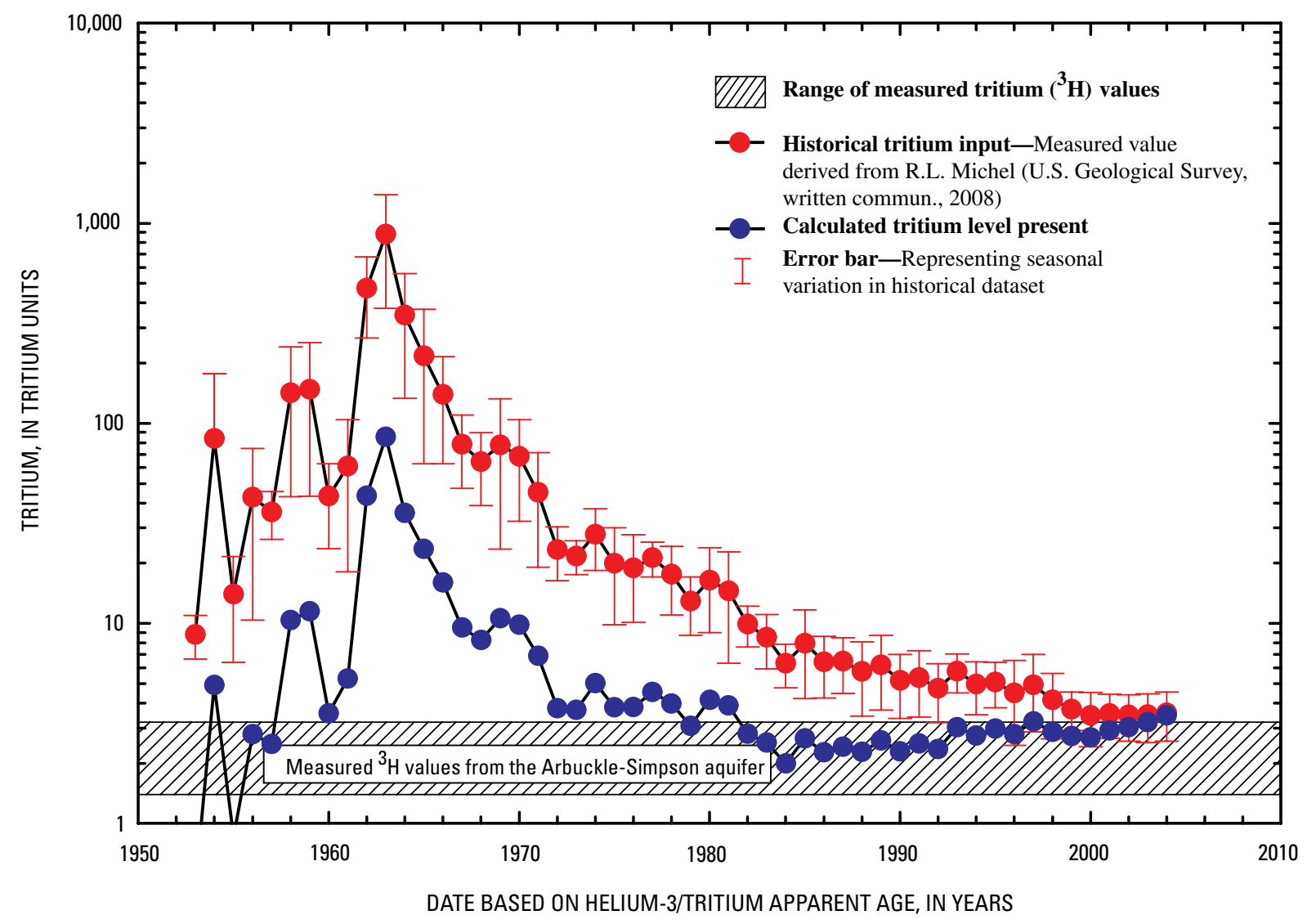

Figure 11. Historical measured tritium ( ${ }^{3} \mathrm{H}$ ) values in precipitation (from R.L. Michel, U.S. Geological Survey, written commun., 2008) and the calculated ${ }^{3} \mathrm{H}$ levels present.

\section{Chlorofluorocarbon Apparent Ages}

Measured dissolved concentrations for CFC-11, $\mathrm{CFC}-12$, and $\mathrm{CFC}-113$ are listed in table 9 . As with the ${ }^{3} \mathrm{He}$ data, the ultimate composition of dissolved CFC in solution is a result of solubility conditions present at the water table. Determination of an apparent age for each measured CFC involves using the solubility conditions to estimate the original atmospheric concentration, which is compared to a known atmospheric curve to assess apparent age of the sample. For ${ }^{3} \mathrm{He}$, a closed equilibrium model (fractionated excess air) was invoked to resolve tritiogenic ${ }^{3} \mathrm{He}$, but this model currently has not been applied to CFCs. One reason for this discrepancy in the use of the fractionated or the unfractionated excess air model is that $\mathrm{CFC}$ concentrations in recharging ground waters may not fractionate as much as the helium concentrations due to different solubility. Helium has a low solubility compared to the $\mathrm{CFCs}$, and may partially exsolve from solution under certain recharge conditions even though the CFCs are quantitatively retained. By using the measured dissolved gas data (table 7), a simple, unfractionated excess air model was applied to calculate atmospheric concentrations for the CFC dataset (see table 9). Recharge temperature was assumed to be that of the calculated CE model, although the amount of excess air was calculated to be the original quantity prior to fractionation [see CE model (Aeschbach-Hertig and others, 1999)]. Samples with no associated dissolved gas sample were assigned an arbitrary recharge temperature of $16^{\circ} \mathrm{C}$ and 2 cubic centimeters per kilogram of excess air (samples 5, 23, 27, and 29). An Excel spreadsheet supplied by the U.S. Geological Survey Chlorofluorocarbon Laboratory was used to calculate apparent ages by assuming an altitude of 1,000 feet above sea level, no local enrichment factor, and the atmospheric input curve from Niwot Ridge, Colorado [(Busenberg and Plummer, 2004) CFC concentrations SIO-98 scale]. Apparent ages for all three CFC compounds are presented in table 9, with a preferred apparent age based on laboratory preferences derived from CFC analyses.

CFC apparent age distributions show that a majority of the waters are modern in age (post-1950 waters). Only samples from sites 6 and 15 contained CFC concentrations below detectable limits, which is consistent with the hydrogeology and carbon-14 ages of these sites. However, samples 10 and 14 are close to the lower detection limits; as previously described, site 10 is a well located near the edge of the aquifer, and site 14 is a spring, and both appear to produce a fraction of both young and old water. The sample from site 5 contained CFC concentrations greater than can be 


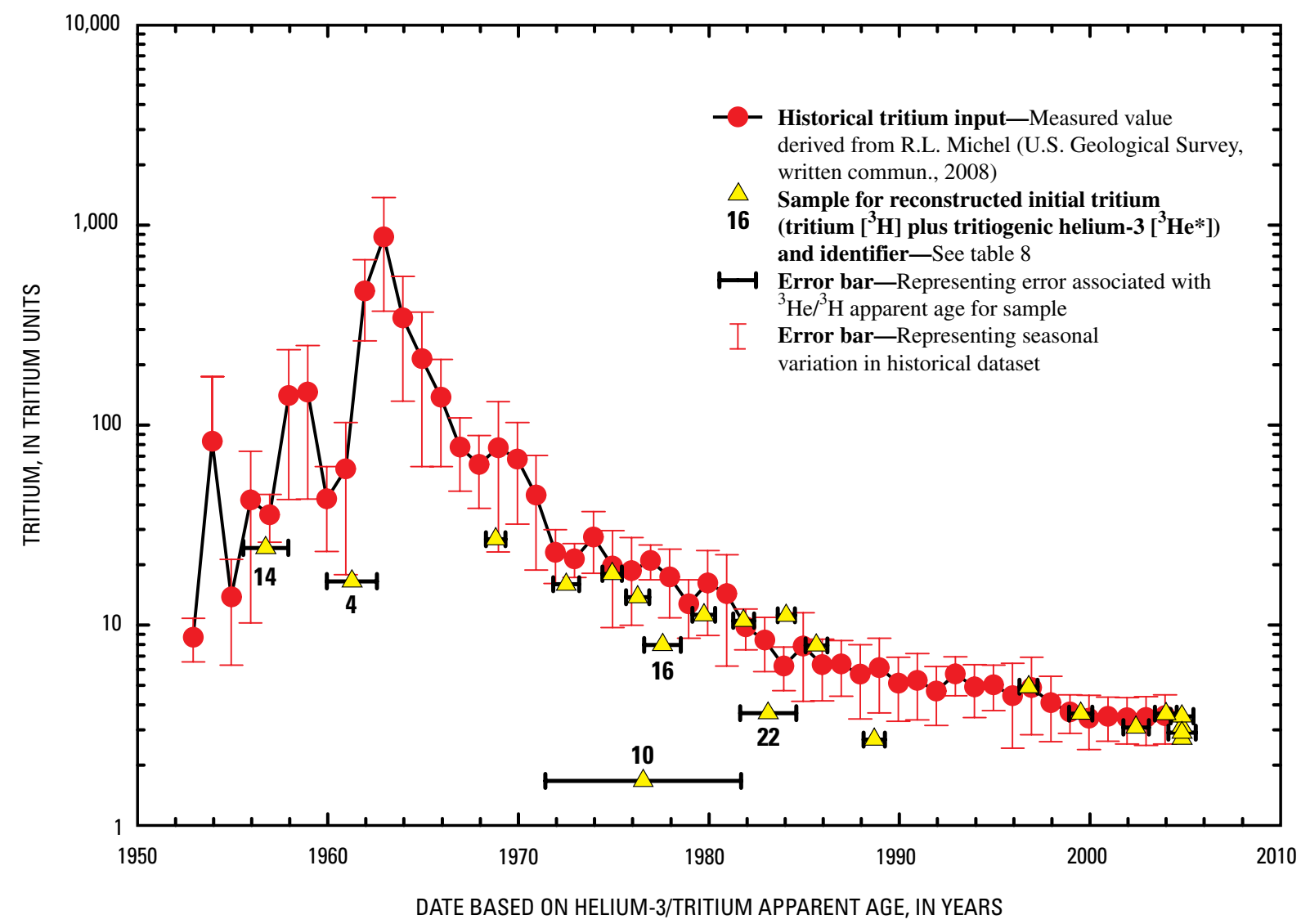

Figure 12. Comparison of reconstructed initial tritium (tritium $\left[{ }^{3} \mathrm{H}\right]$ plus tritiogenic helium-3 $\left[{ }^{3} \mathrm{He}^{*}\right]$ ) to historical tritium input levels.

explained by atmospheric concentrations and the sample from site 1 displayed severe CFC degradation; thus, both apparent age determinations are suspect. Nothing obvious from the hydrogeology at sites 1 and 5 explain these anomalies.

\section{Carbon-14 Apparent Ages}

Excluding the brine sample (sample 31), only 7 samples were sent to a laboratory for analysis of carbon-14. On the basis of helium-3/tritium and CFC dating, all except two contained a substantial fraction of young water. The two samples of old water were from the Vendome Well and site 6. Mole-balance models were calculated for the two water samples (see "Vendome Well and Site 6" section). The adjusted concentrations derived with PHREEQC were entered into NETPATH and the inverse model was recreated with the additional capability to calculate carbon-14 ages. By using the Fontes and Garnier (1979) model in NETPATH for $A_{0}$ (the initial carbon-14 activity for water entering the saturated zone), the apparent carbon-14 ages for the Vendome Well and site 6 samples are calculated to be 10,500 years and 34,000 years. The ages could be about 5,000 years older if an initial carbon-14 activity $\left(A_{0}\right)$ of 100 percent modern carbon is used instead of the Fontes and Garnier (1979) model.

\section{Comparison of Helium-3/Tritium and Chlorofluorocarbon Dating Techniques}

Comparison of two different dating techniques should be a fairly straightforward process in which the apparent ages calculated from each technique should complement one another. This simple concept is not true in all circumstances. The overriding assumption for apparent age consistency is that the ground water sampled has undergone no physicochemical changes that may alter the tracer concentrations since becoming isolated from the atmosphere during recharge, other than radioactive decay. In terms of ground-water dating this is termed piston-flow conditions and should generate apparent ages that represent the true residence time of the ground water sampled. Processes such as ground-water mixing, microbial degradation, sorption, matrix diffusion, hydrodynamic dispersion, contamination (natural and anthropogenic), dissolved gas re-equilibration, and improper application of technique assumptions (for example, recharge temperatures, excess air, or altitude assumptions) can alter the calculated apparent age so that different dating techniques produce vastly different ages (Cook and others, 2006; Han and others, 2006). The process of technique comparison can provide insights to natural processes occurring within the 


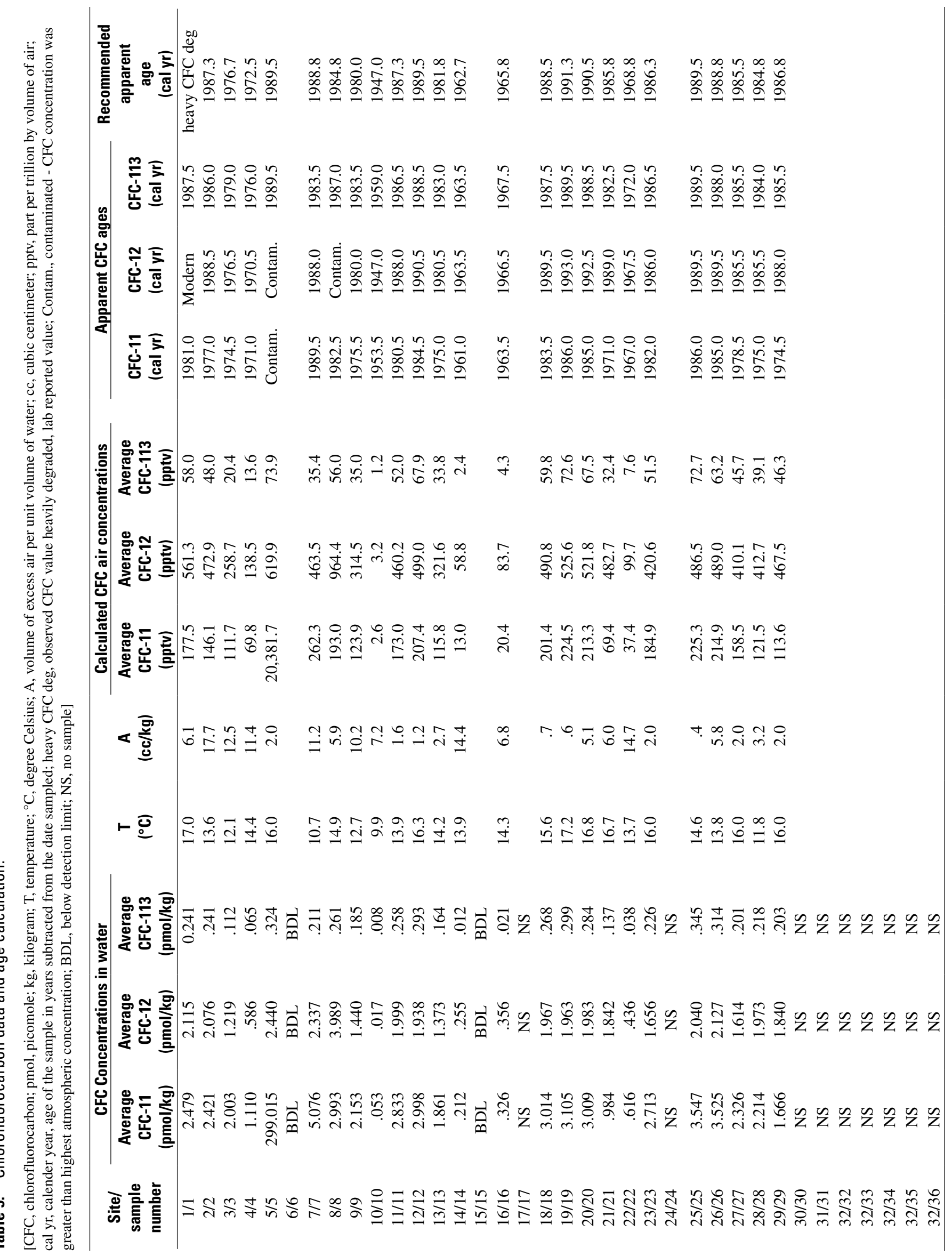


aquifer or anthropogenically induced processes that are a result of sample extraction from the aquifer (for example, mixing within a well annulus or contamination). Concordance of apparent ages from multiple techniques can be used to validate an apparent age as an appropriate residence time for modeling considerations.

A simple comparison between the apparent ages from the $\mathrm{CFCs}$ and ${ }^{3} \mathrm{He} /{ }^{3} \mathrm{H}$ techniques from this study show fairly large differences. Considering analytical error, physical parameter assumptions, and application of solubility models, some degree of difference can be expected between the two techniques ( $+/-5$ yrs would be acceptable), but there is as much as 15 to 29 years difference in some samples, which may be unacceptable. As noted from figure $12\left({ }^{3} \mathrm{He}^{*}\right.$ plus ${ }^{3} \mathrm{H}$ in relation to apparent age), measured data matched well to the tritium input curve (agreement with a piston-flow model) with only a few samples plotting below the curve, indicative of mixing of ${ }^{3} \mathrm{H}$-free water (sub-modern) with modern ground water. Understanding that a binary mixture of modern and submodern water may be a cause for the disagreement of CFC and ${ }^{3} \mathrm{He} /{ }^{3} \mathrm{H}$ apparent ages, this problem was approached by using guidelines from Plummer, Busenberg, and Han (2006). By plotting the ratio of CFC-12 to ${ }^{3} \mathrm{H}_{\text {input }}$ in relation to the recharge year, the effect of simple mixing of modern and sub-modern water (that is, concentration dilution) was eliminated. CFC-12 was chosen from the CFC analyses due to its chemical stability relative to $\mathrm{CFC}-113$ and $\mathrm{CFC}-11$. Plotted in figure 13 is the atmospheric input curve for $\mathrm{CFC}-12$ parts per trillion by volume (pptv) normalized to the average ${ }^{3} \mathrm{H}$ input curve (TU). Because of the variability of ${ }^{3} \mathrm{H}$ signal caused by seasonality in the annual measurements, calculated input curves of CFC-12 normalized by the seasonal high and low values of ${ }^{3} \mathrm{H}$ also are plotted in figure 13. Superimposed on this plot are the measured data from this study, where the calculated atmospheric CFC-12 concentration for each sample is normalized to ${ }^{3} \mathrm{H}+$ ${ }^{3} \mathrm{He}^{*}$ (original ${ }^{3} \mathrm{H}$ input) and plotted in relation to the recharge date as determined by the ${ }^{3} \mathrm{He} /{ }^{3} \mathrm{H}$. A majority of the data fall within the range of input curves, indicating that piston-flow conditions and some binary mixes (modern and sub-modern) can explain the dataset, but as observed in figure 12, samples 4, 10 and 14 fall outside of the curves along with samples 2 and 3 , which were not noted in figure 12 .

In the case of the sample from site 10, the data point falls well below the expected input curves, which can be explained as a result of microbial degradation reducing the concentration of CFC-12 (as well as CFC-11 and CFC-113) making the $\mathrm{CFC}$ age older than the ${ }^{3} \mathrm{He} /{ }^{3} \mathrm{H}$ age. As for samples $2,3,4$, and 14 , the data are above the input curve, indicating either that the CFC-12 is enriched with respect to the calculated ${ }^{3} \mathrm{H}$ input or that ${ }^{3} \mathrm{H}$ is depleted with respect to $\mathrm{CFC}-12$. Samples 2, 3, 4, and 14 contain some amount of terrigenic helium associated with mixing with sub-modern waters, but this mixing should not affect the $\mathrm{CFC}-12 /{ }^{3} \mathrm{H}_{\text {input }}$ ratio. The relative uniformity of the $\mathrm{CFC}$ data discounts the concept of a specific contamination (enrichment of the CFC values) of the samples, which may indicate either that the correction of terrigenic helium is over-correcting ${ }^{3} \mathrm{He}^{*}$ and decreasing the ${ }^{3} \mathrm{H}_{\text {input }}$ value or that some physical or chemical process is separating the $\mathrm{CFC}$ from ${ }^{3} \mathrm{He}$ and ${ }^{3} \mathrm{H}$ components with time. Because the lowest ${ }^{3} \mathrm{He} /{ }^{4} \mathrm{He}$ value $\left(0.02 \mathrm{R} / \mathrm{R}_{\mathrm{A}}\right)$ associated with radiogenic production was used in the correction, the terrigenic helium correction should be conservative in respect to ${ }^{3} \mathrm{He}$ loss. The results must be a combination of binary mixing of modern waters, dispersion of the ${ }^{3} \mathrm{H}$ signal associated with the bomb pulse ${ }^{3} \mathrm{H}$, or a combination of both. Whether mixing or dispersion dominates and how to accurately assess the calculated apparent ages for samples 2, 3, 4, and 14 are unclear at this time. As described previously, sites 4 and 14 are springs where multiple flow lines converge and mixing is anticipated on the basis of the hydrogeology of springs; other lines of geochemical evidence presented in this report also show mixing at these springs.

\section{Terrigenic Helium}

Terrigenic helium was measured in samples from sites 1 , $2,3,4,6,7,9,11,14,15,20,24,30$, and 32 (table 8). In general, terrigenic helium is helium derived from either internal production in the aquifer (Solomon, Hunt, and Poreda, 1996; and Dowling and others, 2004), external flux of helium to the aquifer, mixing with water that is enriched in helium (for example, oilfield brine), or combinations of all of these factors. The amount of terrigenic helium does not correlate well to apparent ${ }^{3} \mathrm{He} /{ }^{3} \mathrm{H}$ age in samples from the Arbuckle-Simpson aquifer, which tends to discount the internal flux of helium from within the aquifer over short time intervals. Possibly terrigenic helium in the Arbuckle-Simpson aquifer is derived by the uptake of He from crustal rocks as ground water travels along long flow paths deep in the aquifer prior to arriving at the sampled site. Terrigenic helium is noted in high concentrations in samples from sites 6 and 15 (7,957.2 and 21,378.6 micro-cubic centimeters per kilogram, respectively), the previously noted flowing wells that contain ${ }^{3} \mathrm{H}$ concentrations below detectable limits. The amounts of terrigenic helium observed in these two samples are several orders of magnitude higher than atmospheric solubility, and the presence of long flow paths at sites 6 and 15 are confirmed by the old carbon-14 ages of water samples from these wells. The presence of very large terrigenic helium concentrations adds additional evidence that ground water in these water samples flowed deep into the aquifer where the ground water picked up helium. Attempting to define crustal He flux rate using the two apparent carbon-14 ages and terrigenic helium concentrations from samples 6 and 15 does not work well. The data contradict the use of terrigenic helium as an age indicator (age does not correlate to terrigenic helium concentration) and supports that the helium concentrations are influenced by mixing with fluids that contain variable amounts of terrigenic helium.

Five sites with terrigenic helium $(4,9,14,20$, and 30) are springs. Samples 4 and 14 show the clearest contribution of sub-modern ground water (fig. 12). Multiple flow paths often 


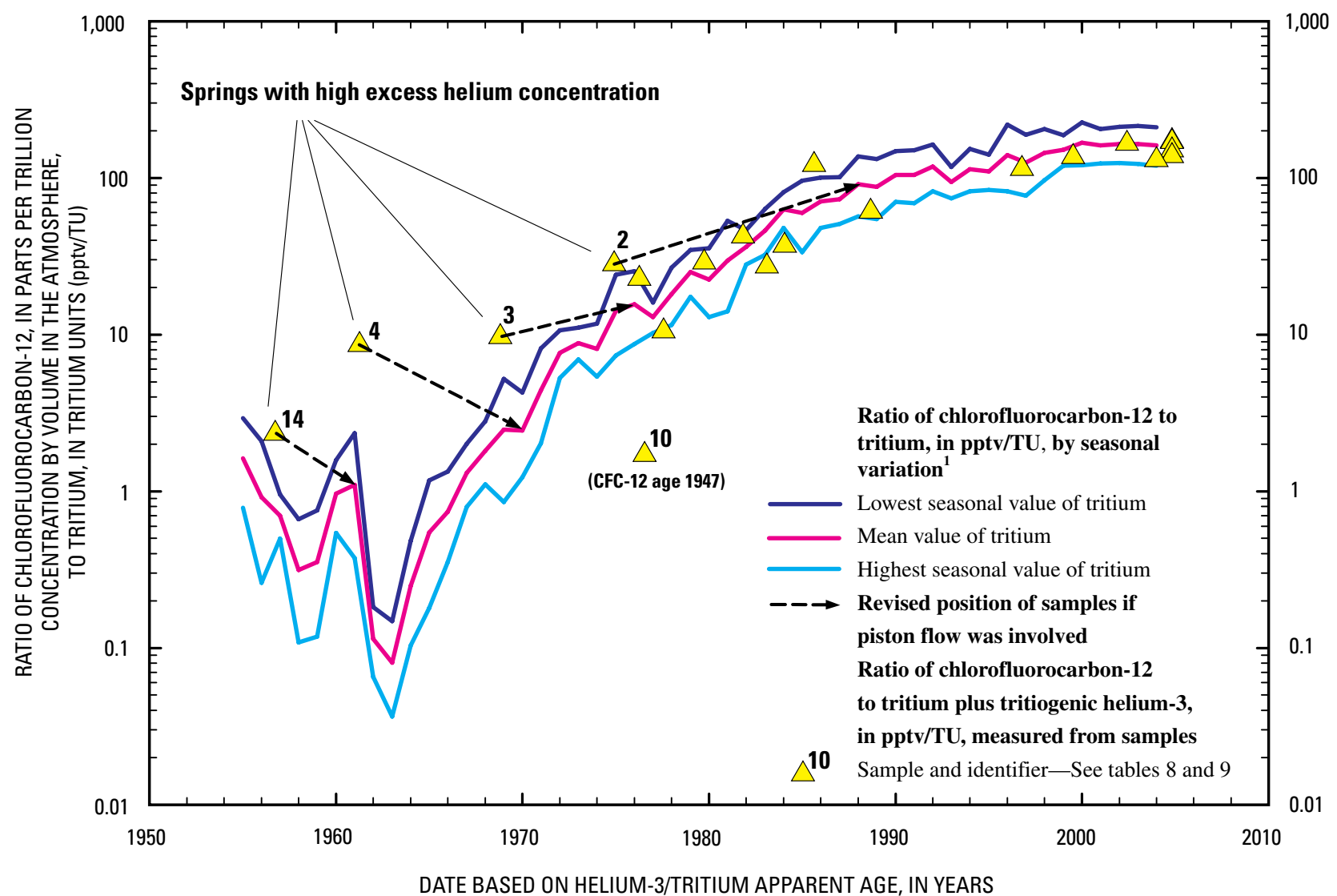

1Data from R.L. Michel (U.S. Geological Survey, written commun., 2008) produced monthly data for tritium. A maximum, minimum, and mean value was generated for each calendar year to represent the seasonal variation of tritium input.

Figure 13. Comparison of helium-3/tritium $\left({ }^{3} \mathrm{He} /{ }^{3} \mathrm{H}\right)$ and chlorofluorocarbon (CFC) dating techniques.

converge at springs, and although the water samples from these sites had modern ground-water ages, it seems likely from the terrigenic helium in these samples that at least some fraction of the water from these springs has flowed along a long, deep flow path before it discharged at the spring. Of the remaining sites with terrigenic helium, three are wells located near discharge areas at the edge of the outcrop of the aquifer (sites 1, 7, and 11), again where multiple flow paths (including flow paths from deep in the aquifer) are likely to converge. The terrigenic helium in samples 2, 3, 24, and 33 (from site 32) indicates that water from these wells may include water that traveled along long, deep flow paths, similar to the water samples from springs. No obvious hydrogeologic features at the wells from which these samples were collected indicate that long, deep flow paths discharge at these locations; the only indication comes from the amounts of terrigenic helium. Alternatively, some other, unknown process may be elevating the He concentration in these water samples.

\section{Summary}

A geochemical reconnaissance investigation of the Arbuckle-Simpson aquifer was initiated in 2004 to characterize the ground-water quality at an aquifer scale, to describe the chemical evolution of ground water as it flows from recharge areas to discharge in wells and springs, and to determine the residence time of ground water in the aquifer. Characterization of aquifer-scale ground-water quality was accomplished by (1) collecting 36 water samples from 32 wells and springs distributed across the aquifer for chemical analysis of major ions, trace elements, isotopes of oxygen and hydrogen, dissolved gases, and age-dating tracers; and (2) calculating descriptive statistics by using the results of the chemical analyses of the water samples. The chemical analyses also were used as input to geochemical models to evaluate the chemical evolution of the water as it moves through the aquifer. Age-dating tracers were used to determine 
the approximate time of recharge and residence time of ground water in the aquifer.

In general, the water from wells and springs in the Arbuckle-Simpson aquifer is chemically suitable for all regulated uses, such as public supplies. Dissolved solids concentrations are low, with a median of $347 \mathrm{mg} / \mathrm{L}$ and an inter-quartile range of 331 to $384 \mathrm{mg} / \mathrm{L}$. Two domestic wells produced water with nitrate concentrations that exceeded the U.S. Environmental Protection Agency's nitrate maximum contaminant level (MCL) of $10 \mathrm{mg} / \mathrm{L}$. Samples from two wells in the confined part of the aquifer, sites 6 and 15, exceeded the secondary maximum contaminant level (SMCL) for chloride of $250 \mathrm{mg} / \mathrm{L}$. Samples from these same two wells also exceeded the SMCL of $500 \mathrm{mg} / \mathrm{L}$ for dissolved solids. Water samples from these two wells in the confined part of the aquifer are not representative of water samples from the other wells and springs completed in the unconfined part of the aquifer, and both wells consistently are exceptional when considering most aspects of the geochemistry of the ArbuckleSimpson aquifer. No other water samples from the ArbuckleSimpson geochemical reconnaissance exceeded MCLs or SMCLs, although not every chemical constituent for which the U.S. Environmental Protection Agency has established a MCL or SMCL was analyzed as part of the Arbuckle-Simpson geochemical investigation.

The major ion chemistry of 34 of the 36 samples indicates the water is a calcium bicarbonate or calcium magnesium bicarbonate water type. Calcium bicarbonate water type is found in the western part of the aquifer, where the Arbuckle Group is predominantly limestone. Calcium magnesium bicarbonate water is found in the eastern part of the aquifer, where the Arbuckle Group is predominantly a dolomite. The major ion chemistry for these 34 samples is consistent with a set of water-rock interactions. Rainfall infiltrates the soil zone, where the host rock, limestone or dolomite, dissolves as a result of uptake of carbon dioxide gas. Some continued dissolution of dolomite and precipitation of calcite occur as the water flows through the saturated zone.

The major ion chemistry of the two samples completed in the confined part of the aquifer indicates the water is a sodium chloride type, which is different from water samples from the unconfined part of the aquifer. Geochemical inverse modeling determined a relatively simple set of reactions that account for the compositions of the two water samples. Mixing the calcitesaturated recharge water with brine and dissolving calcite, dolomite, and gypsum accounts for each of the water compositions. The mole transfers of minerals are similar between the two samples. The primary difference between the two models is that site 15, Vendome Well in Chickasaw National Recreation Area, has a larger mixing fraction of brine, about 1 percent, compared to site 6 , about 0.5 percent. The mixing fractions also account for the concentrations of bromide and iodide in the two samples, which are expected to be conservative constituents of the brine. Although site 6 is about 25 miles from the Vendome Well and from the well where the brine was sampled, the same brine composition accounts for the conservative elements in the site 6 sample, which indicates a brine of similar composition is present below the entire freshwater zone of the Hunton Anticline part of the ArbuckleSimpson aquifer. The brine component of the sample at Vendome Well is likely to account for the relatively large concentrations of many of the trace elements (potassium, fluoride, bromide, iodide, ammonia, arsenic, boron, lithium, selenium, and strontium).

Carbon-14, helium-3/tritium, dissolved gas, and chlorofluorocarbons were used to calculate ground-water ages, recharge temperatures, and mixtures of ground water in the Arbuckle-Simpson aquifer. Based on multiple age-dating tracers, 34 of 36 water samples collected to characterize the aquifer-scale water quality recharged the aquifer after 1950. Consistency between chlorofluorocarbon and helium-3/ tritium age tracers within the samples support the concept that ground-water flow is characterized by piston-flow conditions with relatively young ages (post-1950s waters). The fact that most of the sampled ground water was modern (less than 55 years) indicates that water is moving quickly from recharge areas to discharge to streams and springs. Two exceptions to this classification were noted in samples 6 and 15. Groundwater ages determined at these two sites by using carbon-14 are 34,000 years (site 6) and 10,500 years (site 15).

Concentrations of dissolved argon, neon, and xenon in water samples were used to determine the temperature of the water when it recharged the aquifer. Resolved recharge temperatures vary greatly within the study area. The mean annual air temperature at Ada, Oklahoma, is $16^{\circ} \mathrm{C}$ and the median temperature of the 30 reconnaissance water samples is $18.1^{\circ} \mathrm{C}$. The average recharge temperature of most samples is $14.3+/-2.2^{\circ} \mathrm{C}$, which is below the mean annual air temperature $\left(16^{\circ} \mathrm{C}\right)$. The 2-degree difference could indicate recharge to the aquifer occurs in the cooler seasons, the noble gas modeling (error propagation of CE model) is biased for colder temperatures, or possible sample collection error. Calculating a weighted annual recharge temperature based on mean monthly recharge rates, from hydrograph separation techniques of stream gage data at Blue River at Connerville, and mean monthly air temperature at Ada, Oklahoma, produces a value of $14.2^{\circ} \mathrm{C}$. This recharge temperature corroborates the calculated noble gas recharge temperatures and indicates that recharge occurs during the cooler months of the year. Recharge temperatures of water samples from sites 6 and 15, the two flowing wells producing water from confined parts of the aquifer, are clearly too cold $\left(8.2\right.$ and $6.6^{\circ} \mathrm{C}$, respectively) to be associated with present day temperatures. The colder recharge temperatures are consistent with the ground-water ages for these samples $(34,000$ years for site 6 and 10,500 years for site 15), indicating recharge from an earlier, cooler time period, coupled with possible mass fractionation of the noble gases that decreases the overall recharge temperature. Recharge temperatures for water samples from sites 7 and 10 also are colder than anticipated, 10.7 and $9.9^{\circ} \mathrm{C}$, respectively. Both wells are completed in the Simpson Group near the edge of the aquifer, in a hydrogeologic environment where 
produced water may be a mixture of modern and sub-modern water.

Terrigenic helium was measured in samples from some wells and springs. Terrigenic helium in water samples from the Arbuckle-Simpson aquifer is probably derived by the uptake of helium from crustal rocks, such as the igneous rocks that underlie the aquifer. Ground water that travels deep in the flow system may pick up terrigenic helium from these rocks prior to arriving at the sampled site. Terrigenic helium is in high concentrations from samples at sites 6 and 15. The amounts of helium observed in these two samples are several orders of magnitude higher than atmospheric solubility, and the presence of long flow paths at sites 6 and 15 are confirmed by the old carbon-14 ages of water samples from these wells. Five sites with terrigenic helium concentrations are springs in the Hunton Anticline part of the aquifer. Multiple flow paths often converge at springs, and although the water samples from these sites had modern ground-water ages, it seems likely from the terrigenic helium in these samples that at least some fraction of the water from these springs has flowed along a long, deep flow path before being discharged at the spring.

\section{References Cited}

Aeschbach-Hertig, W., Peeters, F., Beyerle, U., and Kipfer, R., 1999, Interpretation of dissolved atmospheric noble gases in natural waters: Water Resources Research, v. 35, p. 2,779-2,792.

Andrews, J.N., 1985, The isotopic composition of radiogenic helium and its use to study groundwater movement in confined aquifers: Chemical Geology, v. 49, no. 1-3, p. 339-351.

Andrews, W.J., and Burrough, S.P., 2002, Hydrology and water quality near Bromide Pavilion in Chickasaw National Recreation Area, Murray County, Oklahoma, 2000: U.S. Geological Survey Water-Resources Investigations Report 01-4250, $31 \mathrm{p}$.

Appelo, C.A.J., and Postma, D., 2005, Geochemistry, groundwater and pollution (2nd ed.): Leiden, The Netherlands, A.A. Balkema Publishers, 649 p.

Bayer, R., Schlosser, P., Bonisch, G., Rupp, H., Zaucker, F., and Zimmek, G., 1989, Performance and blank components of a mass spectrometric system routine measurement of helium isotopes and tritium by ${ }^{3} \mathrm{He}$ in-growth method: Sitzungsberichte der Heidelberger Akademie der Wissenschaften. Mathematisch Naturwissenschaftliche Klasse, Jahrgang: Heidelberg, Springer Verlag, p. 241-279.

Böhlke, J.K., 2006, TRACERMODEL1. Excel workbook for calculation and presentation of environmental tracer data for simple groundwater mixtures, in Use of chlorofluocarbons in hydrology — A guidebook: Vienna, International Atomic Energy Agency, 277 p.

Boyd, D.T., 2002, Oklahoma oil and gas fields: Oklahoma Geological Survey Geologic Map GM36, 128 p.

Busenberg, E., and Plummer, L.N., 2004, Atmospheric mixing ratios of CFC-11, CFC-12, CFC-113 and $\mathrm{SF}_{6}$ in North America $(\mathrm{NH})$ and CFCs in Southern Hemisphere (SH) air compiled by the U.S. Geological Survey Chlorofluorocarbon Laboratory, accessed November 21, 2008, at http://water.usgs.gov/lab/software/air_curve/.

Busenberg, E., Plummer, L.N., Cook, P.G., Solomon, D.K., Han, L.E., Gröning, M., and Oster, H., 2006, Sampling and analytical methods, in Use of chlorofluocarbons in hydrology_A guidebook: Vienna, International Atomic Energy Agency, 277 p.

Campbell, J. A. and Weber, J. L., 2006, Wells drilled to basement in Oklahoma: Oklahoma Geological Survey Special Publication 2006-1.

Castro, M.C., Stute, M., and Schlosser, P., 2000, Comparison of ${ }^{4} \mathrm{He}$ ages and ${ }^{14} \mathrm{C}$ ages in simple aquifer systems-Implications for groundwater flow and chronologies: Applied Geochemistry, v. 15 , no. 8 , p. 1,137-1,167.

Cederstrand, J.R., 1996, Digital geologic map of ArdmoreSherman quadrangles, south-central Oklahoma: U.S. Geological Survey Open-File Report 96-370, accessed November 21, 2008, at http://ok.water.usgs.gov/gis/geology

Cerling, T.E., 1984, The stable isotopic composition of modern soil carbonate and its relationship to climate: Earth and Planetary Science Letters, v. 43, p. 229-240.

Childress, C.J.O., Foreman, W.T., Connor, B.F., and Maloney, T.J., 1999, New reporting procedures based on long-term method detection levels and some considerations for interpretations of water-quality data provided by the U.S. Geological Survey National Water Quality Laboratory: U.S. Geological Survey Open-File Report 99-193, 19 p.

Cook, P.G., Plummer, L.N., Solomon, D.K., Busenberg, E., and Han, L.F., 2006, Effects and processes that can modify apparent CFC age, in Use of chlorofluorocarbons in hydrology - A guidebook: Vienna, International Atomic Energy Agency, 277 p.

Coplen, T.B., Wildman, J.D., and Chen, J., 1991, Improvements in the gaseous hydrogen-water equilibration technique for hydrogen isotope ratio analysis: Analytical Chemistry, v. 63, p. 910-912.

Donovan, R.N., 1991, The Arbuckle Group-An aide de memoire, in Johnson, K.S., ed., Arbuckle Group Core Workshop and Field Trip: Oklahoma Geological Survey Special Publication 91-3, p. 199-208. 
Dowling, C.B., Poreda, R.J., Hunt, A.G., and Carey, A.E., 2004, Ground water discharge and nitrate flux to the Gulf of Mexico: Ground Water, v. 42, no. 3, p. 401-417.

Drever, J.I., 1982, The geochemistry of natural waters: Englewood Cliffs, New Jersey, Prentice Hall, 388 p.

Epstein, S., and Mayeda, T., 1953, Variation of O-18 content of water from natural sources: Geochimica et Cosmochimica Acta, v. 4, p. 213-224.

Fairchild, R.W., Hanson, R.L., and Davis, R.E., 1990, Hydrology of the Arbuckle Mountains area, south-central Oklahoma: Oklahoma Geological Survey Circular 91, 112 p., 2 plates, scale 1:100,000.

Farnsworth, R.K., and Thompson, E.S., 1982, Mean monthly, seasonal, and annual pan evaporation for the United States: Washington, D.C., National Oceanic and Atmospheric Administration Technical Report NWS 34, 82 p.

Fishman, M.J., ed., 1993, Methods of analysis by the U.S. Geological Survey National Water Quality LaboratoryDetermination of inorganic and organic constituents in water and fluvial sediments: U.S. Geological Survey OpenFile Report 93-125, 217 p.

Fontes, Jean-Charles, and Garnier, Jean-Marie, 1979, Determination of the initial ${ }^{14} \mathrm{C}$ activity of the total dissolved carbon-A review of the existing models and a new approach: Water Resources Research, v. 15, p. 399-413.

Hallberg, G.R., and Keeney, D.R., 1993, Nitrate, in Alley, W.M., ed, Regional ground-water quality: New York, Van Nostrand Reinhold, p. 297-322.

Ham, W.E., 1955, Field conference on the geology of the Arbuckle Mountain region: Oklahoma Geological Survey Guide Book III, 61 p.

Ham, W.E., 1973, Regional geology of the ArbuckleMountains, Oklahoma: Oklahoma Geological Survey Special Publication 73-3, $61 \mathrm{p}$.

Han, L.F., Groning, M., Plummer, L.N., and Solomon, D.K., 2006, Comparison of the CFC technique with other techniques $\left({ }^{3} \mathrm{H},{ }^{3} \mathrm{H} /{ }^{3} \mathrm{He},{ }^{85} \mathrm{Kr}\right)$, in Use of chlorofluorocarbons in hydrology-A guidebook: Vienna, International Atomic Energy Agency, 277 p.

Hanson, R.L. and Cates, S.W., 1994, Hydrology of the Chickasaw National Recreation Area, Murray County, Oklahoma: U.S. Geological Survey Water-Resources Investigations Report 94-4102, 86 p., 2 plates, scale $1: 24,000$.

Harp, J.F., and McLin, S.S., 1986, A geohydrologic study of the Sulphur artesian ground-water system and associated waters at the Chickasaw National Recreation Area, Sulphur, Oklahoma: Oklahoma University Project No. 155-421, $29 \mathrm{p}$.
Hart, D.L., Jr., 1966, Base of fresh ground water in southern Oklahoma: U.S. Geological Survey Hydrologic Atlas HA-223, 2 sheets, scale 1:250,000.

Heaton, T.H.E., and Vogel, J.C., 1981, "Excess air" in groundwater: Journal of Hydrology, v. 50, p. 201-216.

Helsel, D.R., and Hirsch, R.M., 2002, Statistical methods in water resources: U.S. Geological Survey Techniques of Water-Resources Investigations, book 4, chap. A3, 510 p.

Hunt, A.G., 2000, Diffusional release of helium-4 from mineral phases as indicators of groundwater age and depositional history: Rochester, N.Y., University of Rochester, Doctoral thesis, $140 \mathrm{p}$.

Johnson, K.S., ed., 1991, Arbuckle Group core workshop and field trip: Oklahoma Geological Survey Special Publication 91-3, 266 p.

Kipfer, R., Aeschbach-Hertig, W., Peeters, F., and Stute, M., 2002, Noble gases in lakes and ground waters: Reviews in Mineralogy and Geochemistry, v. 47, p. 615-700.

Koren, V., Schaake, J., Duan, Q., Smith, M., and Cong, S., 1998, PET Upgrades to NWSRFS, Project Plan, unpublished report, August 13, 1998, accessed September 12, 2006, at http://www.nws.noaa.gov/oh/hrl/dmip/fws.html

Lucas, L.L., and Unterweger, M.P., 2000, Comprehensive review and critical evaluation of the half-life of tritium: Journal of Research of the National Institute of Standards and Technology, v. 105, p. 541-549.

Lynch, Mark, and Al-Shaieb, Zuhair, 1991, Evidence of paleokarstic phenomena and burial diagenesis in the Ordovician Arbuckle Group of Oklahoma, in Johnson, K.S., ed., Late Cambrian-Ordovician Geology of the Southern Midcontinent, 1989 Symposium: Oklahoma Geological Survey Circular 92, p. 42-60.

Marine, I.W., 1979, The use of naturally occurring helium to estimate groundwater velocities for studies of geologic storage of radioactive waste: Water Resources Research, v. 15 , no. 5 , p. $1,130-1,136$.

McCrae, J.M., 1950, On the isotope chemistry of carbonates and a paleotemperature scale: Journal of Chemical Physics, v. 18, p. $849-857$.

Mook, W.G., Bommerson, J.C., and Staverman, W.H., 1974, Carbon isotope fractionation between dissolved bicarbonate and gaseous carbon dioxide: Earth and Planetary Science Letters, v. 22, p. 169-176.

National Climatic Data Center, 2006, Climatography of the United States, No. 20, 1971-2000: Ada, Oklahoma, Precipitation Totals, accessed September 29, 2006, at http://cdo. ncdc.noaa.gov/climatenormals.clim20/ok/340017.pdf

National Elevation Dataset, 2001, National Elevation Dataset homepage, accessed November 14, 2001, at http://ned.usgs. gov 
Oklahoma Water Resources Board, 2003, The ArbuckleSimpson Hydrology Study-Management and protection of an Oklahoma water resource: Oklahoma Water Resources Board Fact Sheet, 4 p.

Parkhurst, D.L., and Appelo, C.A.J., 1999, User's guide to PHREEQC (version 2) - A computer program for speciation, batch-reaction, one-dimensional transport, and inverse geochemical calculations: U.S. Geological Survey WaterResources Investigations Report 99-4259, 312 p.

Parkhurst, R.S., and Christenson, S.C., 1987, Selected chemical analyses of water from formations of Mesozoic and Paleozoic age in parts of Oklahoma, northern Texas, and Union County, New Mexico: U.S. Geological Survey Water Resources Investigations Report 86-4355, 222 p.

Plummer, L.N., 2005, Dating of young groundwater, in Aggarwal, P.K., Gat, J.R., and Froehlich, K.F.O., eds., Isotopes in the water cycle-Past, present and future of a developing science: Dordrecht, The Netherlands, Springer Verlag, p. 193-220.

Plummer, L.N., and Busenberg E., 1999, Chlorofluorocarbons, in Cook, P., and Herczeg, A., eds., Environmental tracers in subsurface hydrology, Chapter 15: Kluwer Academic Press, p. $441-478$.

Plummer, L.N., Busenberg, E., and Cook, P.G., 2006, Principles of chlorofluorocarbon dating, in Use of chlorofluorocarbons in hydrology-A guidebook: Vienna, International Atomic Energy Agency, 277 p.

Plummer, L.N., Busenberg, E., and Han, L.F., 2006, CFCs in binary mixtures of young and old groundwater, in Use of chlorofluorocarbons in hydrology-A guidebook: Vienna, International Atomic Energy Agency, 277 p.

Plummer, L.N., Prestemon, E.C., and Parkhurst, D.L., 1994, An interactive code (NETPATH) for modeling net geochemical reactions along a flow path, version 2: U.S. Geological Survey Water-Resources Investigations Report 94-4169, $130 \mathrm{p}$.

Savoca, M.E., and Bergman, D.L., 1994, Effects of municipal ground-water withdrawals on the Arbuckle-Simpson aquifer, Pontotoc County, Oklahoma: U.S. Geological Survey Water-Resources Investigations Report 94-4230, 37 p.

Scheirer, D.S., and Hosford Scheirer, Allegra, 2006, Gravity investigations of the Chickasaw National Recreation Area, south-central Oklahoma: U.S. Geological Survey Open-File Report 2006-1083, 40 p.
Schlosser, P., Stute, M., Sonntag, C., and Muennich, K.O., 1989, Tritiogenic ${ }^{3} \mathrm{He}$ in shallow groundwater: Earth and Planetary Science Letters, v. 94, no. 3-4, p. 245-256.

Solomon, D.K., Hunt, A., and Poreda, R.J., 1996, Source of radiogenic helium 4 in shallow aquifers-Implications for dating young groundwater: Water Resources Research, v. 32 , no. 6 , p. $1,805-1,813$.

Stuiver, Minze, and Polach, H.A., 1977, Discussion of reporting of ${ }^{14} \mathrm{C}$ data: Radiocarbon, v. 19 , no. 3, p. 355-363.

Stute, M., Schlosser, P., Clark, J.F., and Broecker, W.S., 1992, Paleotemperatures in the Southwestern United States derived from noble gases in ground water: Science, v. 256, no. 5059 , p. 1,000-1,003.

Stute, M., and Sonntag, C., 1992, Palaeotemperatures derived from noble gases dissolved in groundwater and in relation to soil temperature, in Loosli, H.H., and Mazor, E., eds., Isotopes of noble gases as tracers in environmental studies, Panel Proceedings Series: Vienna, International Atomic Energy Agency, p. 111-122.

Torgersen, T., and Clarke, W.B., 1985, Helium accumulation in groundwater, I-An evaluation of sources and the continental flux of crustal (super 4) He in the Great Artesian Basin, Australia: Geochimica et Cosmochimica Acta, v. 49, no. 5 , p. $1,211-1,218$.

U.S. Environmental Protection Agency, 2006, List of drinking water contaminants and MCLs, accessed September 25, 2006, at http://www.epa.gov/safewater/mcl.html\#mcls

Vieux, B.E., and Calderon, Camilo, 2005, Distributed estimation of recharge and streamflow in the Arbuckle-Simpson aquifer region: Norman, Okla., University of Oklahoma School of Civil Engineering and Environmental Science, unpublished report, $56 \mathrm{p}$.

Wilde, F.D., Radtke, D.B., Gibs, Jacob, and Iwatsubo, R.T., eds., 1998, National field manual for the collection of waterquality data: U.S. Geological Survey Techniques of Water Resources Investigations, book 9, chap. 1-9.

Zuber, A., 1986, Mathematical models for the interpretation of environmental radioisotopes in groundwater systems, in Fritz, P., and Fontes, J.C., eds., Handbook of environmental geochemistry, volume 2: Elsevier, p. 1-59. 
Appendix 1 
Blank Page 


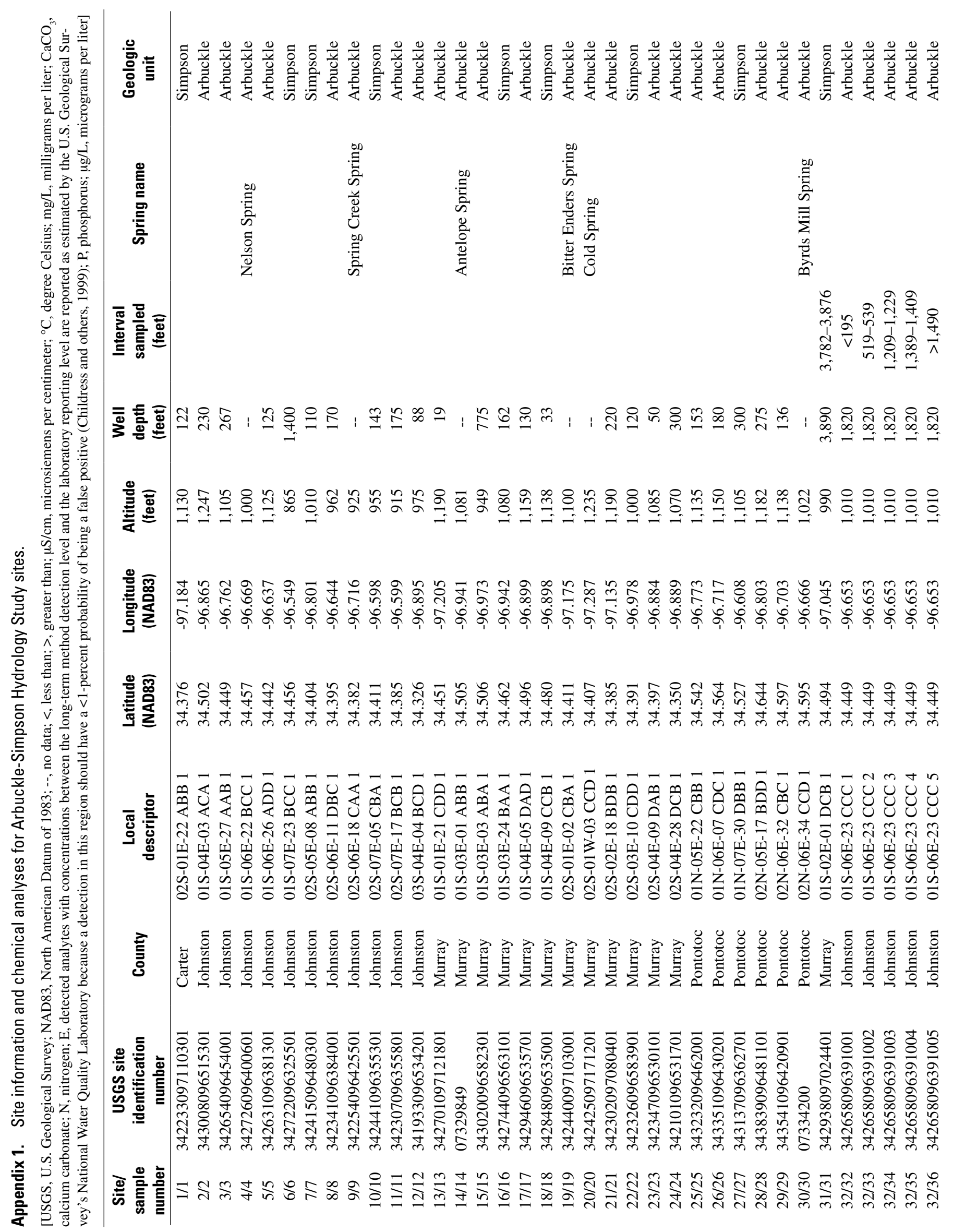




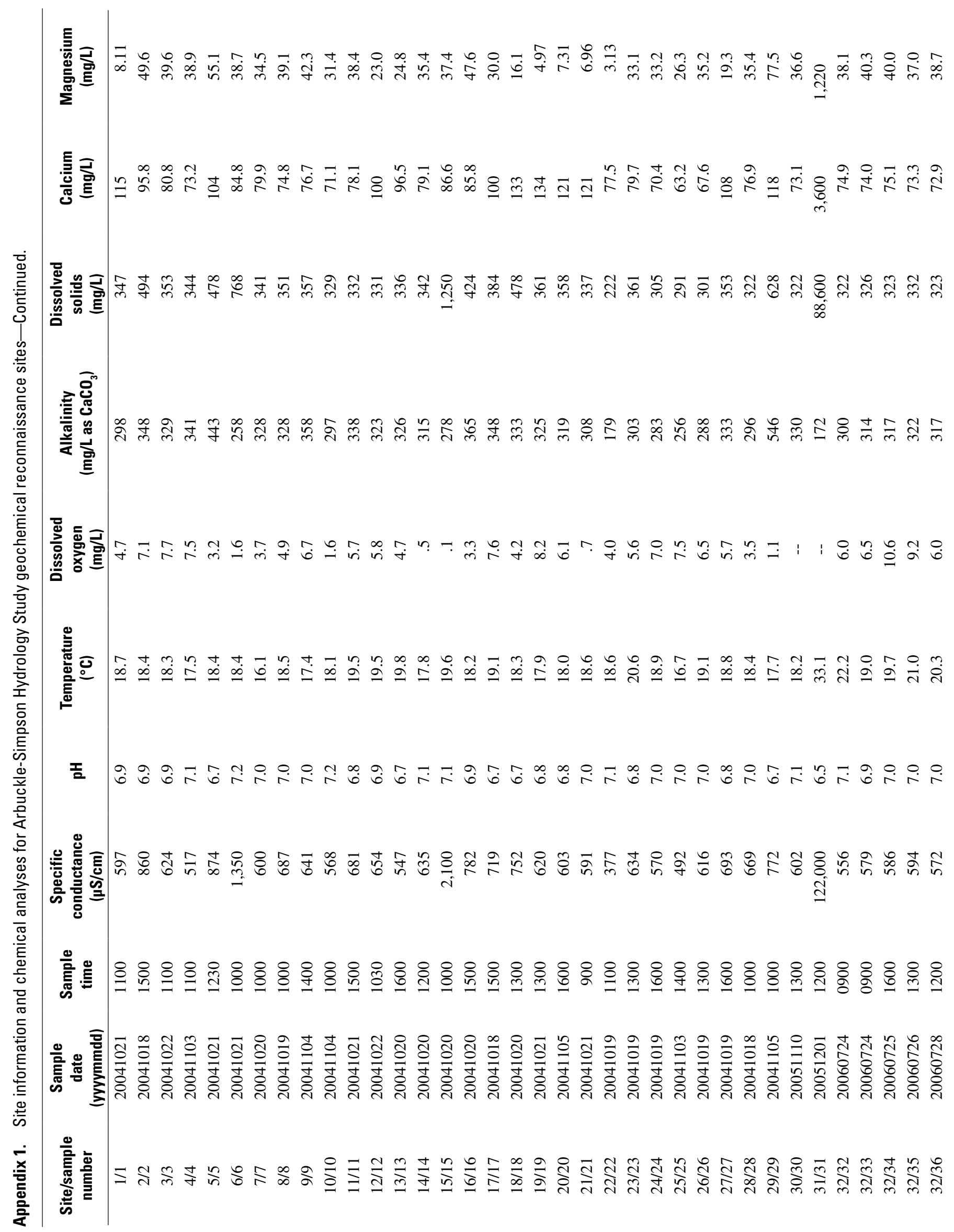




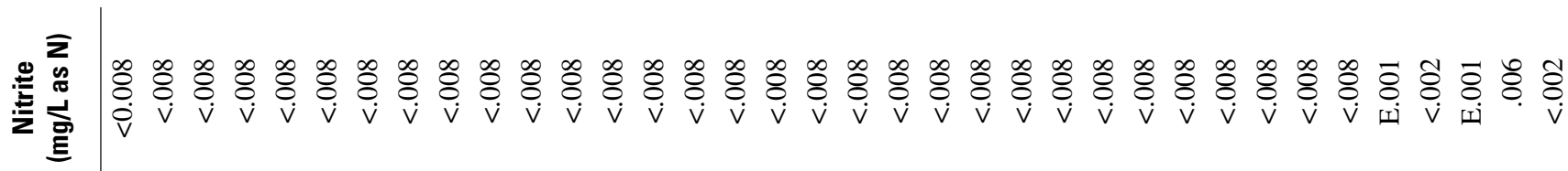

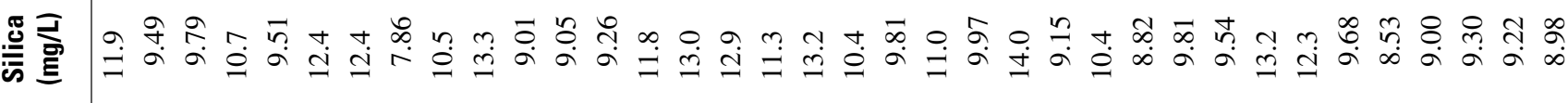

亲

产奇

章焉

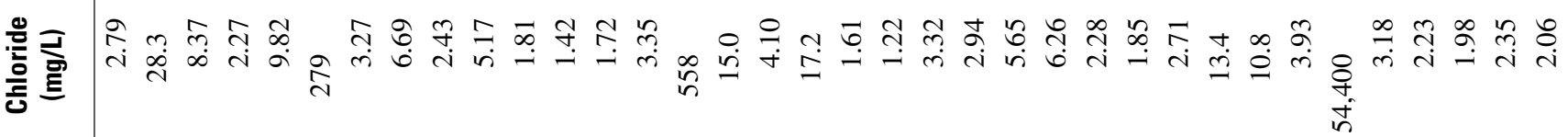

兽

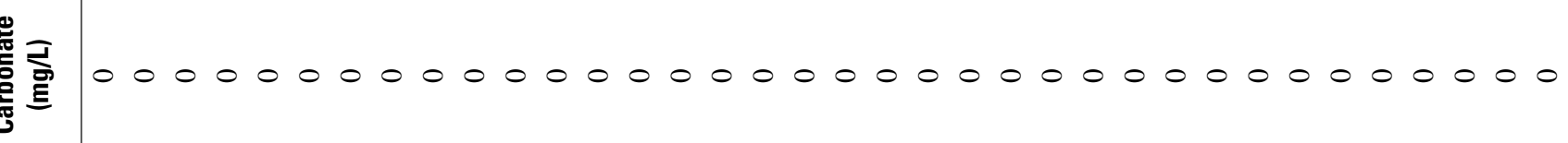

产

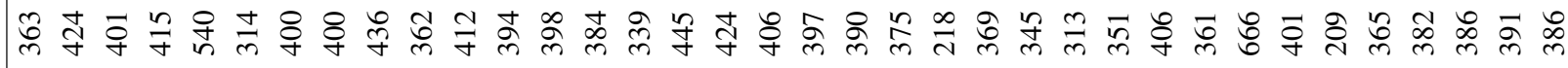

in

衰

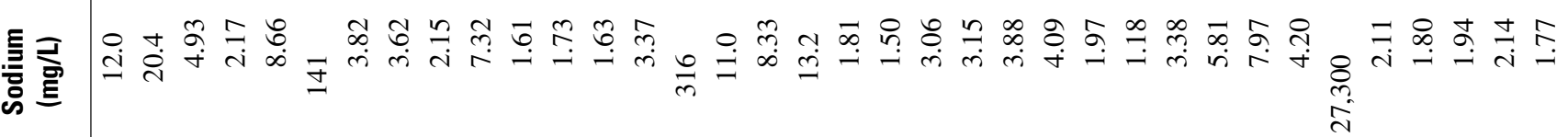
离 


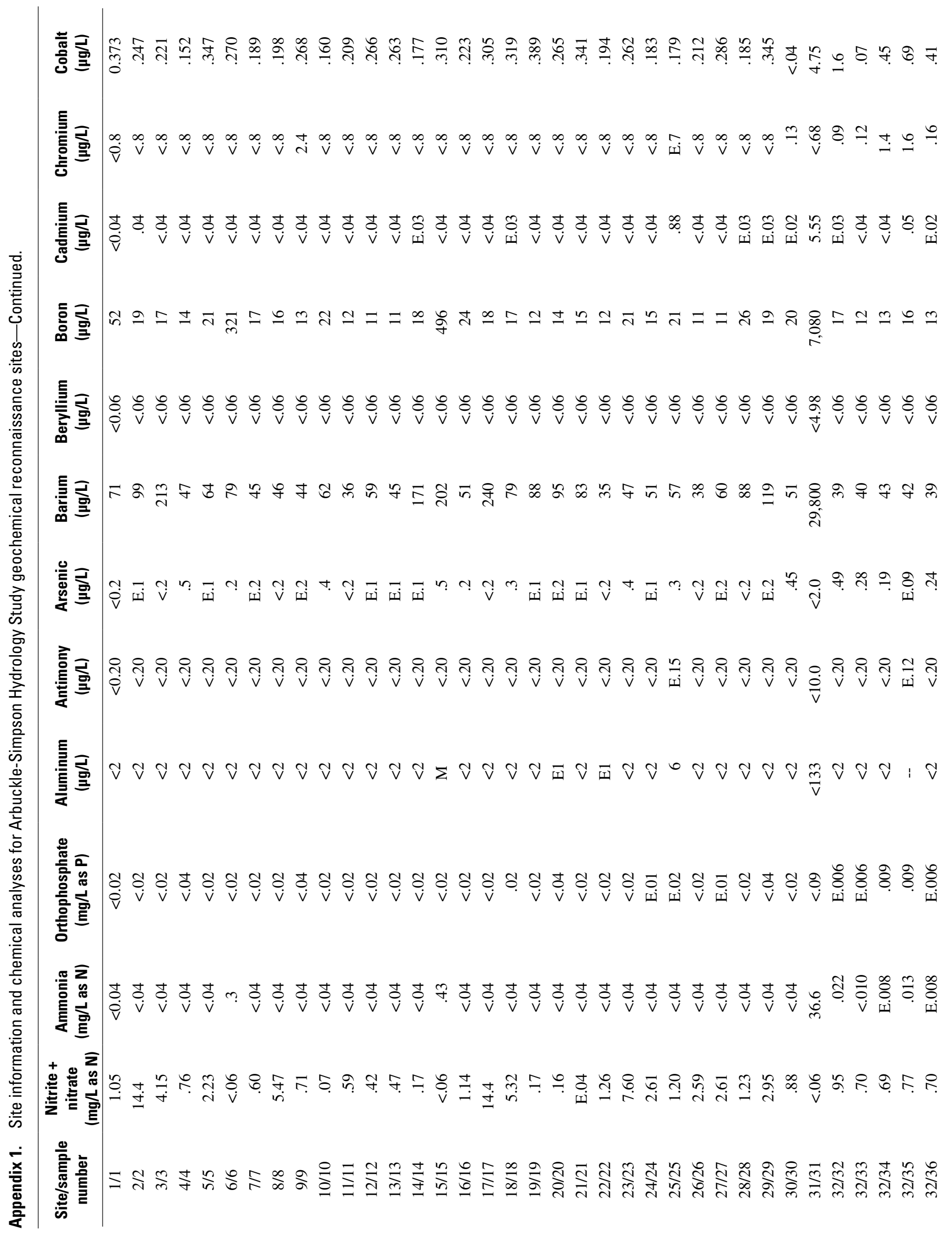




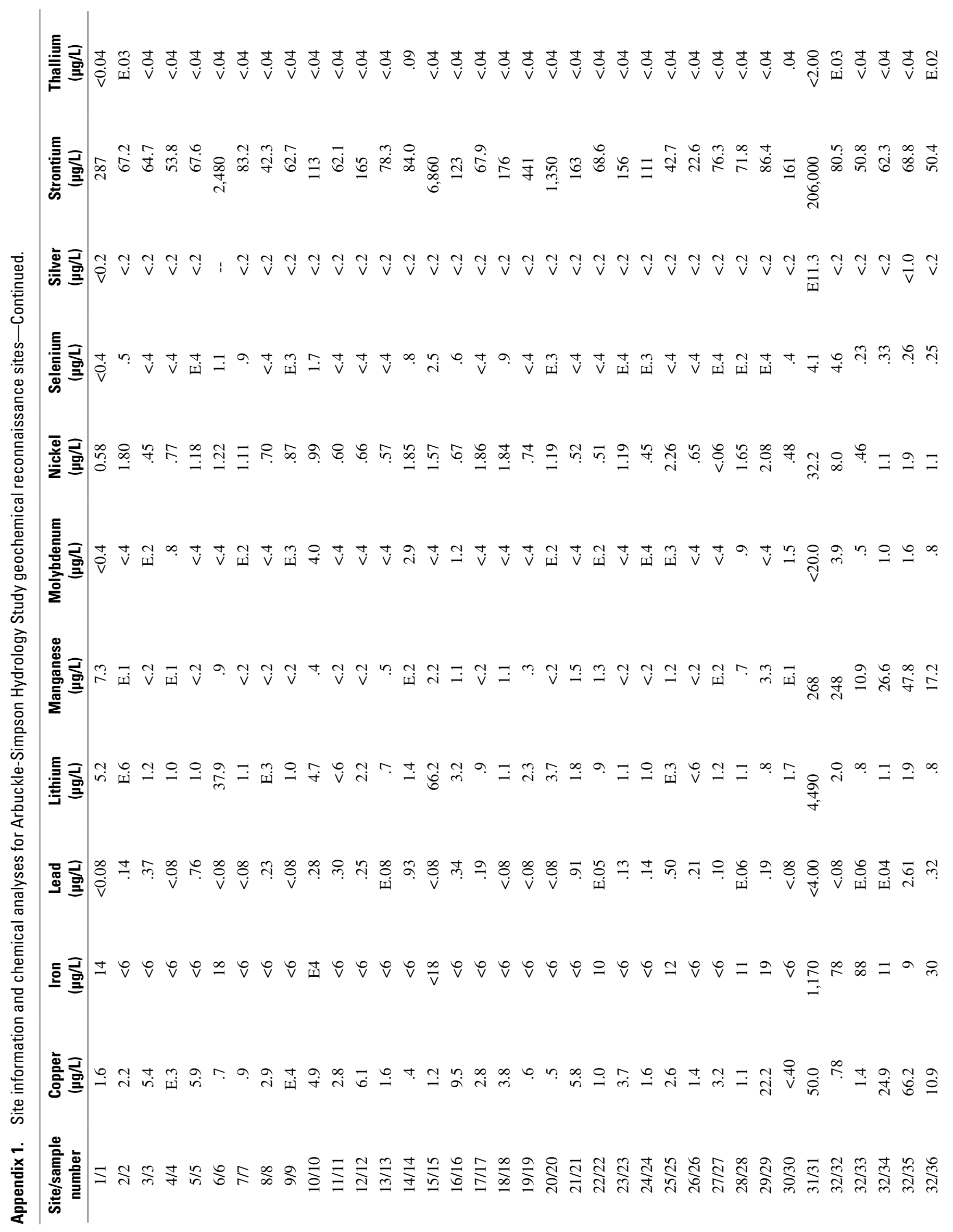




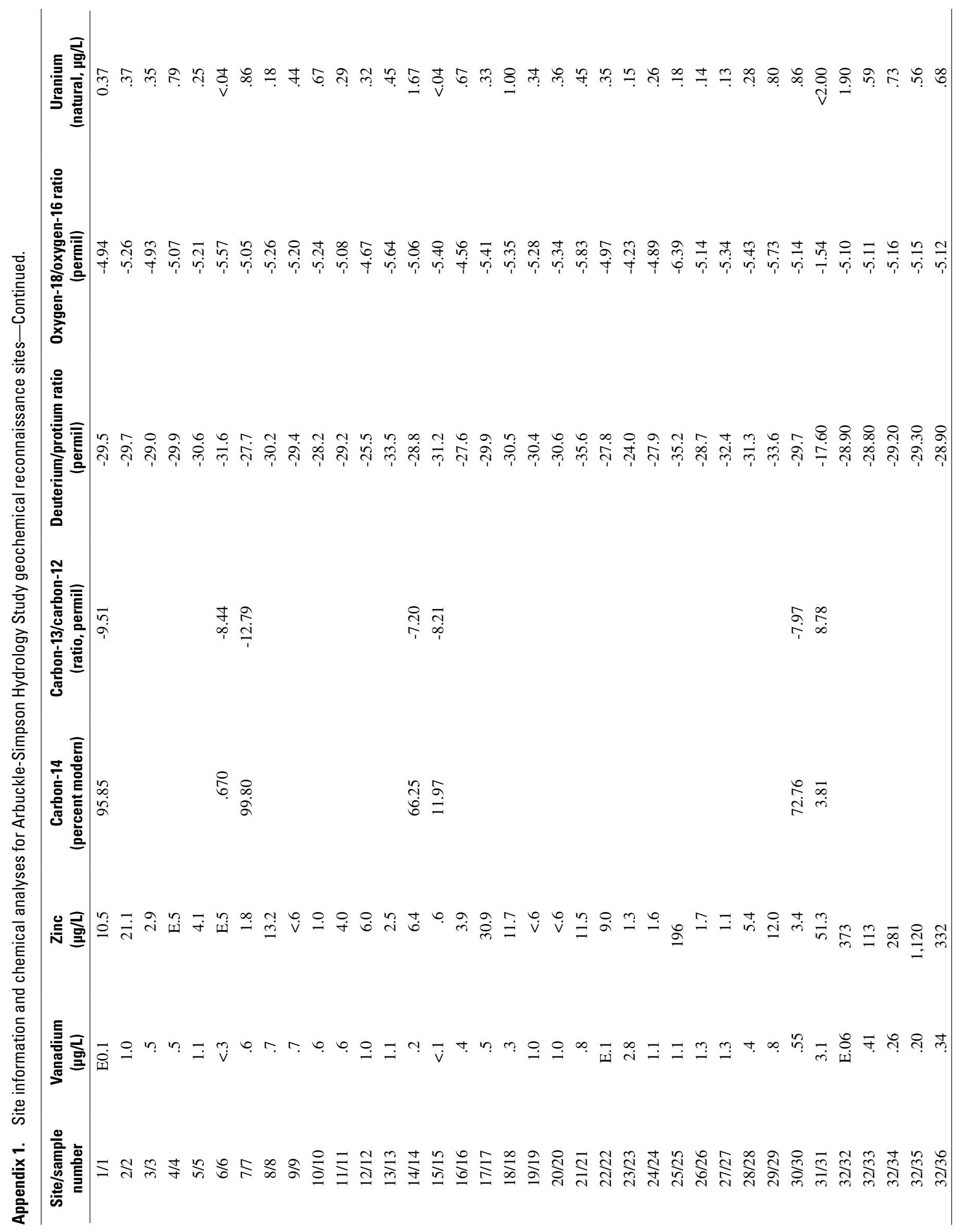


Publishing support provided by

Lafayette Publishing Service Center

For more information concerning this publication, contact: Director, USGS Oklahoma Water Science Center

202 NW 66th St., Bldg. 7

Oklahoma City, OK 73116

(405) 810-4400

Or visit the Oklahoma Water Science Center Web site at: http://ok.water.usgs.gov 
